\title{
Natural Antioxidant and Anti-Inflammatory Compounds in Foodstuff or Medicinal Herbs Inducing Heme Oxygenase-1 Expression
}

\author{
Dongyup Hahn ${ }^{1,2,+}$, Seung Ho Shin ${ }^{3,+}$ and Jong-Sup Bae ${ }^{4, *}$ \\ 1 School of Food Science and Biotechnology, College of Agriculture and Life Sciences, Kyungpook National \\ University, Daegu 41566, Korea; dohahn@knu.ac.kr \\ 2 Department of Integrative Biology, Kyungpook National University, Daegu 41566, Korea \\ 3 Department of Food and Nutrition, Institute of Agriculture and Life Science, Gyeongsang National \\ University, Jinju 52828, Korea; shshin@gnu.ac.kr \\ 4 College of Pharmacy, CMRI, Research Institute of Pharmaceutical Sciences, BK21 Plus KNU Multi-Omics \\ based Creative Drug Research Team, Kyungpook National University, Daegu 41566, Korea \\ * Correspondence: baejs@knu.ac.kr \\ + These authors contributed equally to this work.
}

Received: 29 October 2020; Accepted: 24 November 2020; Published: 27 November 2020

\begin{abstract}
Heme oxygenase-1 (HO-1) is an inducible antioxidant enzyme that catalyzes heme group degradation. Decreased level of HO-1 is correlated with disease progression, and HO-1 induction suppresses development of metabolic and neurological disorders. Natural compounds with antioxidant activities have emerged as a rich source of HO-1 inducers with marginal toxicity. Here we discuss the therapeutic role of HO-1 in obesity, hypertension, atherosclerosis, Parkinson's disease and hepatic fibrosis, and present important signaling pathway components that lead to HO-1 expression. We provide an updated, comprehensive list of natural HO-1 inducers in foodstuff and medicinal herbs categorized by their chemical structures. Based on the continued research in HO-1 signaling pathways and rapid development of their natural inducers, HO-1 may serve as a preventive and therapeutic target for metabolic and neurological disorders.
\end{abstract}

Keywords: heme oxygenase-1; antioxidant; anti-inflammatory compound; foodstuff; medicinal herbs

\section{Introduction}

Since the discovery of heme oxygenase-1 (HO-1) by Tenhunen et al. in 1968 [1], three HO isoenzymes (HO-1, HO-2 and HO-3) have been reported in mammals [2]. Heme oxygenase (HO) mostly exists in two forms, HO-1, the inducible form, and HO-2, the constitutive form [3]. HO-3 is a pseudogene derived from the HO-2 transcript, and has any intron [4]. HO-1 and HO-2 degrade heme in an identical stereospecific manner to biliverdin with the concurrent release of carbon monoxide (CO) and iron [5]. Among those three proteins, only HO-1 was shown to be inducible by a variety of stimuli such as oxidative stress [6,7]. On the other hand, the constitutive nature of HO-2 made it less attractive as a drug target compared to HO-1.

Recent studies utilizing gene knockdown techniques and small molecule inhibitors have shown that HO-1 induction suppresses development of metabolic disorders and nerve system disorders including obesity [8], hypertension [9], atherosclerosis [10], Parkinson's disease [11] and hepatic fibrosis [12]. A significant body of literature has focused on the mechanism of heme degradation by HO- 1 and there is strong evidence that inducing HO-1 expression is an effective method of suppressing oxidative dysregulation, inadequate immune response and related disorders [13]. 
Chemoprevention is defined as a pharmacological approach used to suppress or reverse the disease progression [14]. Antioxidants in fruits and vegetables, such as polyphenols, have been proposed as primary chemopreventive agents [15]. Many of the natural compounds have shown the ability to induce HO-1 without cytotoxic effects. Although several reviews have dealt with natural HO-1 inducers [16-18], none of them categorized and visualized their chemical structures of the up-to-date list of HO-1 inducers. Given the importance of chemical structures of natural compounds on their antioxidant ability, it is necessary to provide the chemical structure-based classification of HO-1 inducers. Here, we provide a compilation of knowledge on natural antioxidants and anti-inflammatory compounds in foodstuff or medicinal herbs focusing on the diseases in which HO-1 induction could exert preventive or therapeutic effects by modulating various signaling pathways.

\section{Beneficial Effects of Heme Oxygenase-1 Induction as Preventive Measures against Diseases}

HO-1 is involved in a wide range of diseases in many types of mammalian tissue including the liver, artery and neuron. Although the effect of HO-1 induction is controversial in some types of diseases, there are several cases showing the benefits of antioxidant and anti-inflammatory effects of HO-1. Here we introduced five types of diseases in which HO-1 induction is confirmed to be beneficial by genetic knockout experiments in vitro and in vivo.

\subsection{Obesity}

Obesity, characterized by increased adipose tissue mass that results from both increased number and size of fat cells [19], is one of the major metabolic disorders worldwide [20]. Obesity is also a major risk factor in vascular dysfunction and insulin resistance that leads to hypertension and diabetes, respectively [21,22]. Decreased level of HO-1 was correlated with the inflammatory cytokine increase and insulin resistance [8,23]. In animal studies, the beneficial effect of HO-1 induction against adipocyte morphology was observed in the $o b / o b$ mouse model [8] and Zucker diabetic rats [24]. Administration of $3 \mathrm{mg} / \mathrm{kg}$ of cobalt protoporphyrin (CoPP), the HO-1 inducer that causes a sustained increase in the HO-1 protein level, prevented weight gain by decreasing visceral and subcutaneous fat content compared with the vehicle group [8]. Upregulation of HO-1 attenuated adipogenesis in bone marrow by increasing serum adiponectin, and decreasing plasma tumor necrosis factor-alpha (TNF-alpha), interleukin (IL)-6 and IL-1 $\beta$ levels [8]. Upregulating the HO-system with hemin also reduced perirenal adiposity in the Zucker rat model by inhibiting several proinflammatory/oxidative mediators in perirenal fat including macrophage-inflammatory-protein- $1 \alpha$ (MIP- $1 \alpha)$, endothelin (ET-1), 8-isoprostane, TNF- $\alpha$, IL-6 and IL-1 $\beta$ [24]. The increase of HO- 1 in perirenal fat was confirmed by enzyme-linked immunosorbent assay (ELISA) showing the involvement of the obesity regulator in vivo [24]. These results indicate that the HO-1 level is negatively correlated with obesity-related symptoms and HO-1 induction ameliorates genetically induced obesity in vivo.

\subsection{Hypertension}

Hypertension, a long-term medical condition where the blood pressure in the artery is persistently elevated, is now considered as a chronic progressive disease that develops over many years [25]. Hypertension is a major risk factor of stroke, myocardial infarction, left ventricular hypertrophy and renal disease $[26,27]$. There are various reports showing the protective role of HO-1 in the development and progression of pulmonary arterial hypertension. In an animal study, transgenic mice that overexpress HO-1 in the lung showed reduced incidence of pulmonary hypertension and vessel wall hypertrophy induced by hypoxia [9]. The levels of proinflammatory cytokines and chemokines induced by hypoxia were also suppressed in HO-1 transgenic mice [9]. Another in vivo study using a HO-1 inducer also showed that hemin treatment abrogated the induction of pulmonary hypertension and pulmonary arterial wall thickening in rats injected with monocrotaline [28]. Adipose tissue-specific induction of HO-1 also demonstrated the beneficial effect of HO-1 against obesity-related hypertension. 
Induction of HO-1 lowered blood pressure levels in obese mice similar to that of lean mice [29]. These studies highlight the protective role of the HO-1 signaling in hypertensive models in vivo.

\subsection{Atherosclerosis}

Atherosclerosis is characterized by the accumulation of lipids and fibrous elements in the large arteries [30]. Since atherosclerosis was regarded as a chronic inflammatory state, the effect of HO-1 modulation in the disease has been studied extensively. Case reports on deficiency of HMOX1, a human gene encoding HO-1 enzyme, showed vascular injury and early atherosclerotic changes along with inflammation and nephropathy, suggesting the importance of HO-1 in vascular health [31-33]. The protective role of HO-1 induction against atherosclerosis was further supported by various animal studies. HO-1 overexpression by adenovirus-mediated gene transfer successfully inhibited atherogenesis in a hypercholesterolemic animal model [10]. Induction of HO-1 by pharmacological inducers also attenuated the development of atherosclerotic lesions in vivo $[34,35]$. On the other hand, $\mathrm{Hmox}^{-1-}$ mice reportedly had growth retardation, anemia, iron deposition [36,37] and developed severe aortitis and coronary arteritis with mononuclear cellular infiltration and fatty streak formation [38]. In sum, these results found in mouse and human show that HO-1 plays a protective role against the progression of atherosclerosis.

\subsection{Parkinson's Disease}

Parkinson's disease is one of the major neurodegenerative disorders of uncertain pathogenesis characterized by the loss of the dopaminergic neurons [39]. The deregulation of the HO system has been associated with many types of neurodegenerative disorders, particularly Parkinson's disease $[5,40]$. HO-1 induction showed a neuroprotective role in in vivo models of Parkinson's disease [11,41]. Hung et al. utilized an adenovirus containing human HO-1 gene and injected it into rat substantia nigra concomitantly with 1-methyl-4-phenylpyridinium that causes parkinsonism. Overexpression of HO-1 significantly increased the survival rate of dopaminergic neurons, and reduced the production of TNF- $\alpha$ and IL-1 $\beta$ in substantia nigra [11]. Another in vivo study revealed that intracerebral administration of a natural HO-1 inducer also suppressed the dopaminergic neuronal loss and behavioral dysfunction in the 6-OHDA mouse model. Dopaminergic neurons from oxidative stress were protected by upregulation of glial expression of HO-1 [42]. Thus, the increase of HO-1 can be beneficial to suppress neuronal damage and progression of Parkinson's disease.

\subsection{Hepatic Fibrosis}

Hepatic fibrosis is overly exuberant wound healing that excessive connective tissue builds up in the liver [43]. It is an integral part in chronic liver disease progression, ultimately leading to cirrhosis and hepatocellular carcinoma [44]. HO-1 has been implicated to play an important role in antioxidative stress and cytoprotective systems in the liver. Increased level of HO-1 induced SIRT1 and ameliorated fructose-mediated liver fibrosis by decreasing vascular dysfunction in mice [12]. Cobalt protoporphyrin (CoPP), a HO-1 inducer, was able to suppress oxidative stress markers and negate HO-1 decrease by fructose intake [12]. On the other hand, HO-1 deficiency in mouse models and human caused severe chronic hepatic inflammation, iron deposition and oxidative damage in the liver $[45,46]$. Most importantly, HO-1 induction reduced liver damage and chronic inflammation by regulating immune cell infiltration or proliferation and TNF receptor signaling in Mdr2 knockout mice, a genetic mouse model of chronic liver inflammation and fibrogenesis [47]. Fibrosis progression was significantly reduced by HO-1 induction with CoPP [47]. Although the therapeutic potential of HO-1 and its mechanism of action are still largely unknown in patients, upregulation of HO-1 gene expression is a potential future clinical implication to improve metabolic balance and attenuate hepatic fibrosis. 


\section{HO-1 Signaling Pathway}

Considering the clinical implications of HO-1 mentioned above, elucidating the signaling pathway of HO-1 and understanding the molecular mechanism are crucial. Here we categorize HO-1 signaling pathway into two segments: upstream kinases and transcription factors of HO-1. Key proteins that regulate transcription factors of HO-1 include extracellular signal-regulated kinase (ERK), c-Jun N-terminal kinase (JNK), p38 and Akt (Figure 1). Transcription factors that bind to upstream of the initiation site of HO-1 to stimulate its mRNA expression include nuclear factor erythroid 2-related factor 2 (Nrf2), nuclear factor kappa-light-chain-enhancer of activated B cells (NF- $\mathrm{kB}$ ) and activator protein 1 (AP-1). After expressed by the regulator proteins, HO-1 affects downstream elements such as Heme, bilirubin and carbon monoxide (CO).

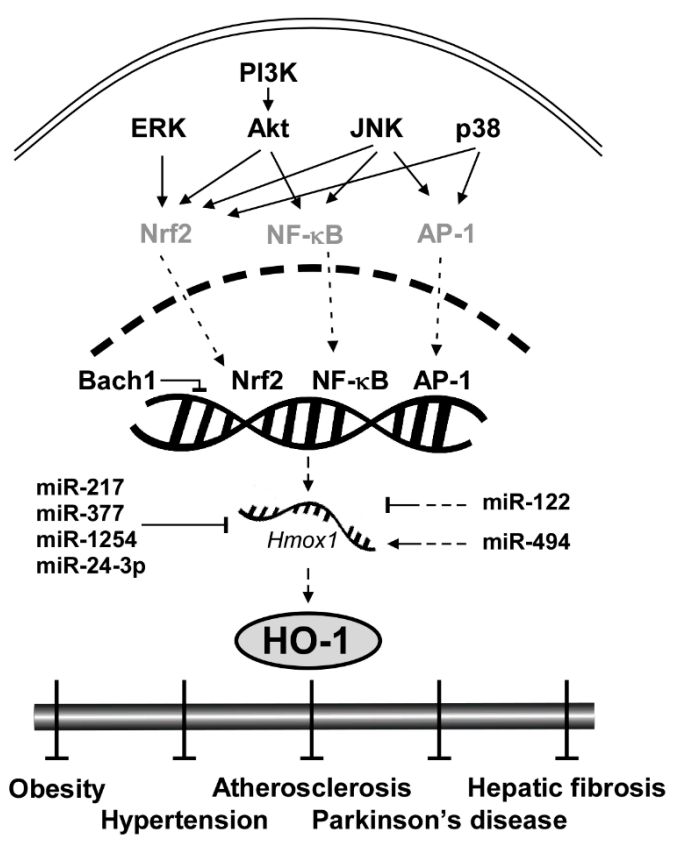

Figure 1. General scheme of signaling pathways in HO-1 induction.

\subsection{Upstream Kinases: ERK, JNK, p38 and Akt}

ERK, a member of the mitogen-activated protein kinase (MAPK) family, is involved in cellular processes including proliferation [48], differentiation [49] and redox regulation [50]. ERK was reportedly involved in induction of HO-1 by extracellular signals or chemopreventive small molecules [51,52]. Chen and Maines utilized PD98059, a selective ERK pathway inhibitor, and showed that inhibition of ERK blocked HO-1 induction by a nitric oxide donor in a dose-dependent manner [51]. Wu et al. also revealed that pretreatment of PD98059 can prevent HO-1 induction by epigallocatechin-3-gallate (EGCG) [52]. Nrf2 is a well-known transcription factor regulated by ERK to induce HO-1 mRNA expression [53]. Several studies using phytochemicals showed that the activation of the antioxidant regulator, Nrf2, is mediated through ERK phosphorylation [53-55].

JNK is another member of MAPK that plays a central role in stress signaling pathways implicated in gene expression, neuronal plasticity and regulation of cellular senescence [56]. Pharmacological inhibitor studies showed that JNK regulates the HO-1 expression level [57]. In rat hepatocytes, the JNK inhibitor SP600125 decreased HO-1 mRNA expression mediated by sodium arsenite [57]. JNK regulates Nrf2 to reduce oxidative stress [58,59]. Pretreatment of SP600125 suppressed Nrf2 translocation under the oxidative stress signal [58]. SP600125 suppressed the JNK signaling pathway and resulted in Nrf2-mediated prevention of diabetic nephropathy [59]. Moreover, JNK also activates NF- $k B$ and Nrf2 [60]. Tsai et al. found that siRNA of JNK inhibited glucose-induced activation of NF- $\mathrm{KB}$ in cardiomyocytes [60]. 
p38, the other member of MAPK family, plays an important role in redox regulation [51], cellular stress response [61] and autophagy [62] via regulating HO-1. An in vitro study using a p38 inhibitor, SB203580, revealed that the inhibition of p38 suppressed the induction of HO-1 by nitric oxide in a dose-dependent manner [51]. Another study also showed that siRNA of p38 MAPK and pretreatment of SB203580 attenuated HO-1 induction in fisetin-stimulated human umbilical vein endothelial cells [63]. The induction of HO-1 by p38 is also correlated with Nrf2 activation. Khayandirobilide A, a natural small molecule with anti-inflammatory property, induces HO-1 expression by p38 MAPK/Nrf2 signaling in RAW264.7 macrophages and BV-2 microglial cells [64].

Akt, a substrate of phosphoinositide 3-kinase (PI3K), is a serine/threonine-specific protein kinase that plays a key role in oxidative damage response [58], cell cycle progression [65] and survival [66]. PI3K-Akt pathway induces HO-1 expression level as a survival signal against oxidative stress-induced injuries [67]. Mo et al. found that hydrogen peroxide enhanced phosphorylation of Akt and that treatment with LY294002, a selective inhibitor of PI3K, suppressed Akt phosphorylation and hydrogen peroxide-induced HO-1 expression [67]. Another study also confirmed the role of the PI3K-Akt pathway on HO-1 expression and further elucidated that Nrf2 is involved in the process. Pretreatment of LY294002 prevented nuclear translocation of Nrf2 and inhibited HO-1 induction in RAW 264.7 cells [58]. In sum, ERK, JNK, p38 and PI3K-Akt pathways govern the HO-1 expression level primarily by regulating important transcription factors such as Nrf2 and NF-kB.

\subsection{Transcription Factors: Nrf2, NF- $\kappa B$ and AP-1}

HO-1 gene (Hmox1) is located on chromosome 22q12, and is regulated by several transcription factors including Nrf2, NF- $\mathrm{kB}$ and AP-1 [5]. This feature makes HO-1 a converging node in antioxidant mechanism [5] and serves as a critical signaling protein of ferroptosis regulating iron and ROS (reactive oxygen species) homeostasis [68-72]. Nrf2, for instance, is a family member of Cap ' $n$ ' Collar-basic leucine zipper transcription factor (CNC-bZIP) and is considered as the most pivotal regulator of HO-1 in the brain and nervous system [73]. Without oxidative stress, Nrf2 is located in the cytoplasm by its negative regulator Keap1 that induces ubiquitination and proteasomal degradation of Nrf2 [74]. Under oxidative stress conditions, Keap1 is dissociated from Nrf2 and thus Nrf2 moves into the nucleus, binds to the antioxidant response elements (AREs) sequence of the HO-1 promoter region and initiates the transcription of HO-1 [75]. Once expressed, HO-1 activates a cascade of antioxidant signaling that affects the oxidative status of the cells and protects cells from oxidative challenges [23]. Knockdown experiments confirmed that downregulation of Nrf2 significantly inhibited H-Ras-induced HO-1 transcription [76].

NF- $\mathrm{kB}$ and AP-1 also directly regulate HO-1 expression as transcription factors. Unlike evolutionary conserved Nrf2-HO-1 regulation, the HO-1 regulation by NF-KB and AP-1 is dependent on lipopolysaccharide (LPS), a prototypical Toll-like receptor 4 (TLR4) agonist [77]. Once TLR4 is stimulated by LPS or monophosphoryl lipid A, another synthetic TLR4 agonist, it activates NF- $\mathrm{B}[78,79]$ and AP-1 [80]. Inhibition of the NF- $\mathrm{BB}$ pathway with small molecules suppressed LPS-induced HO-1 promoter activity [77]. AP-1 homodimers or heterodimers bind to enhancers of the promoter region of hmox1 [81]. The expression of HO-1 requires AP-1 activation by LPS [80].

\subsection{Transcription Repressor: Bach1}

BTB and CNC homology 1 (Bach1) is ubiquitously expressed in mammalian tissues and functions as a transcriptional suppressor of HO-1 by heterodimerizing with small Maf proteins [82]. While Nrf2 reportedly activates HO-1, Bach1 binds to the enhancers of the Hmox1 to suppress its expression under normal conditions [83]. Knockout of Bach1 affects oxidative stress damage by HO-1 induction [84]. Bach1 deficiency reduced the severity of osteoarthritis in mice by inducing HO-1 expression [85]. 


\subsection{Translational Repressor: miRNAs}

MicroRNAs (miRNAs) are a class of small non-coding RNA that govern post-transcriptional gene silencing (PTGS) and affect a wide range of protein expression [86]. There are several miRNAs that downregulate HO-1 both directly and indirectly. miR-217, miR-377, miR-1254 and miR-24-3p directly regulate HO-1 translation. miR-217 and miR-377 in combination showed no change in HMOX1 mRNA levels, but a significant reduction in HO-1 protein expression and enzyme activity [87]. The two miRNAs were able to bind to the $3^{\prime}$ untranslated region ( $3^{\prime}$ UTR) of human HMOX1 [87]. miR-1254 suppresses HO-1 expression at the post-transcriptional level by directly targeting HO-1 3' UTR [86]. $\mathrm{Pu}$ et al. found that HO-1 expression was inversely correlated with miR-1254 level in human cells [86]. miR-24-3p also targets the $3^{\prime}$ UTR of HO-1 [88]. miR-122 and miR-494 indirectly regulate the HO-1 expression level. Antagomir of miR-122 induced HO-1 mRNA levels in vitro [89]. In contrast, miR-494 upregulates the HO-1 expression level. Endogenous miR-494 inhibition impaired HO-1 induction in response to $\mathrm{H}_{2} \mathrm{O}_{2}$ [90]. The effect of miRNAs on HO-1 is illustrated in Figure 1.

\subsection{Enzymatic Activity of HO-1}

Once expressed, HO-1 catalyzes the degradation of heme to yield equimolar amounts of biliverdin, $\mathrm{CO}$ and ferrous iron [91]. The three products have anti-inflammatory and antioxidant activities. First, biliverdin is converted to bilirubin that functions as a vasoactive and antioxidant molecule [23]. Second, $\mathrm{CO}$ interacts with heme proteins or diffuses to the blood stream, and is transported to the lungs and cleared by exhalation [92]. CO also participates in intracellular signal transduction, including production of anti-inflammatory cytokines and upregulation of antiapoptotic effectors [91]. Third, ferrous iron is an essential requirement for the synthesis of hemoglobin and ferritin, and is involved in cellular redox reactions [23]. Figure 2 provides a conceptual illustration of heme degradation by HO-1.

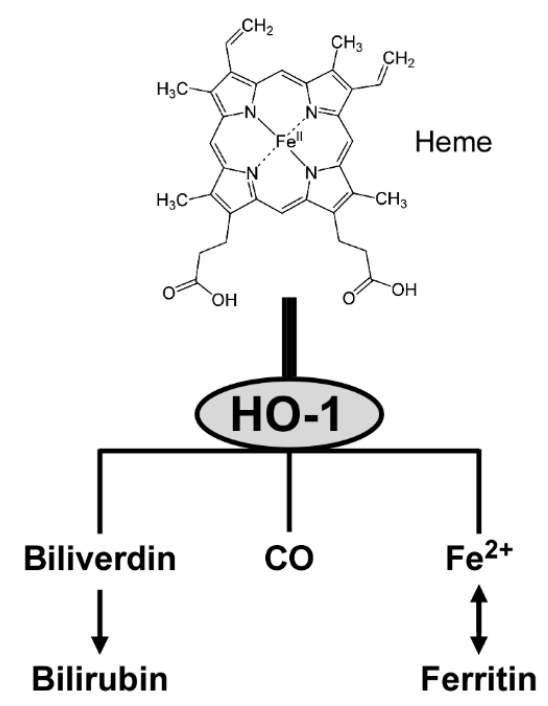

Figure 2. Heme metabolism by HO-1.

\section{Phenolics}

Phenolic compounds are present in most food and medicinal plants, and their antioxidant activity and other pharmacological effects have been reported [93]. The antioxidative effect of phenolics in edible sources have been regarded that the phenolics retard oxidative degradation of lipids by direct quenching of ROS [94]. The studies on the molecular mechanism of health promoting effects of phenolics in edible plants that unraveled the bioactivities are also associated with the antioxidative and anti-inflammatory cascades involved with HO-1. The phenolic compounds are the largest family of antioxidative and anti-inflammatory natural products inducing HO-1 to exert a variety of bioactivities 
including hepatoprotective, cardioprotective, neuroprotective, antiobestic, antidiabetic activity and so on.

\subsection{Flavonoid}

Quercetin (1) is the most common flavonol present in vegetables, fruits and medicinal herbs with antioxidant and anti-inflammatory activity [95]. Besides direct hydrogen-donating properties to quench ROS, the influence of quercetin on signaling pathways and its indirect interaction with the endogenous antioxidative defense system was investigated. Chen et al. revealed the role of quercetin (1) as an inhibitor of iNOS gene expression by inducing HO-1 and mediating the inhibition of IкB kinase, NF- $\mathrm{kB}$ and STAT1 [96]. In addition, upregulation of HO-1 expression by activating the nuclear factor erythroid 2 related factor (Nrf2) to bind with ARE in the ho-1 gene promoter region was also reported [97,98]. The mechanism of the hepatoprotective effects of quercetin (1) on ethanol-induced oxidative damage in hepatocytes was involved in ERK activation and HO-1 upregulation [99]. Later, the signaling pathway of quercetin (1) involved in HO-1 induction was revealed as p38 and ERK mediated quercetin (1)-derived Nrf2 translocation into nuclei and subsequent induction of HO-1 activity [100]. The hepatoprotective effects of quercetin (1) via induction of HO-1 on ethanol-induced microsomal oxidative stress were studied in adult male Sprague-Dawley rats [101]. Quercetin (1) also reduces obesity-induced hepatic inflammation by inducing HO-1, which promotes hepatic macrophage polarization in favor of the M2 phenotype [102]. Quercetin (1) suppresses microglia-mediated inflammatory responses via the induction of HO-1, and hence protects against obesity-induced hypothalamic inflammation [103]. Under obese conditions, muscle atrophy might be induced by $\mathrm{TNF} \alpha$, but it might be reduced through Nrf2-mediated HO-1 induction accompanied by inactivation of NF-KB of quercetin (1) [104]. The therapeutic potential of quercetin (1) for inflammatory diseases via enhancement of mitochondrial biogenesis [105], and reduction of NADPH oxidase-derived superoxide generation and oxidative stress [106]. The suppression of hydrogen peroxide $\left(\mathrm{H}_{2} \mathrm{O}_{2}\right)$-induced cell damage in endothelial cells by quercetin (1) could explain the protective cardiovascular effects of diets rich in the compound [107]. Hayashi et al. reported quercetin (1) attenuates oxidative epithelial cell injury in lung inflammation [108]. Another flavonol compound found in common dietary plants, isorhamnetin (2) also has HO-1 inducing activity, which results in exhibition of the anti-inflammatory effect [109], attenuation of atherosclerosis [110] and protective effects against oxidative stress-induced cellular damage [111]. A flavanol found in Moraceae plants and many medicinal herbs, morin (3) increases induction of HO-1 activity, leading to the anti-inflammatory and antioxidative effects, which implies the potential as a therapeutic for the prevention of neuroinflammation [112] and liver injury [113]. Cytoprotective effect against oxidative stress of fisetin (4) treatment resulted from significantly increased Nrf2 nuclear translocation, and ARE-luciferase activity, leading to upregulation of HO-1 expression [63]. Myricetin (5) is an anti-inflammatory component that the expression of HO-1 through Nrf2 translocation, found in Diospyros lotus, an oriental herbal medicine used for the treatment of diabetes, diarrhea, tumor and hypertension [114]. Apigenin (6) and luteolin (7) are structurally related flavones easily found in dietary plant sources, which activate Nrf2-ARE-mediated gene expression and induce anti-inflammatory activities with important effects on HO-1 expression [115]. Luteolin (7) has been further investigated in mitigation of acute lung injury [116], inhibition of viral-induced inflammatory response [117] and protective effect against renal toxicity [118] via the upregulating Nrf2/ARE/HO-1 pathway. Baicalein (8) is the representative bioactive component found in Scutellaria baicalensis, an oriental herbal medicine [119]. Its improvement of cardiac contractile function in endotoxemic rats [120] and protective activity for pancreatic $\beta$-cells from inflammation [121] might attribute to induction of HO-1 expression. Huang et al. investigated the protective action of three structurally related flavones (chrysin (9), apigenin (6), and luteolin (7)) against oxidative stress in rat primary hepatocytes [122]. Chrysin (9), apigenin (6) and luteolin (7) upregulated the protein expression of HO-1 in a dose-dependent manner and glutamate cysteine ligase catalytic and modifier subunit and increased the intracellular glutathione content and the ratio of glutathione 
to oxidized glutathione [122]. Nobiletin (10), a highly O-methylated flavone isolated from citrus peels, significantly induces HO-1 to inhibit NO production and exert anti-inflammatory effects on the crosstalk between adipocytes and macrophages, which implies potential for the prevention of obesity-related metabolic diseases [123]. Eupatilin (11), the anti-inflammatory flavone derived from Artemisia plants, protects ileal smooth muscle cells (ISMCs) from cell damage caused by indomethacin, and that its cytoprotective action could be attributed to eupatilin-mediated HO-1 induction via ERK and Nrf2 signaling in ISMC [124]. 5-Hydroxy-3,6,7,8,3' $4^{\prime}$-hexamethoxyflavone (12) from Hizikia fusiforme inhibits LPS-stimulated NO production by suppression of iNOS expression and enhancement of HO-1 expression via Nrf2 activation [125]. Structures of the flavonoid natural products (1-12) are presented in Figure 3.

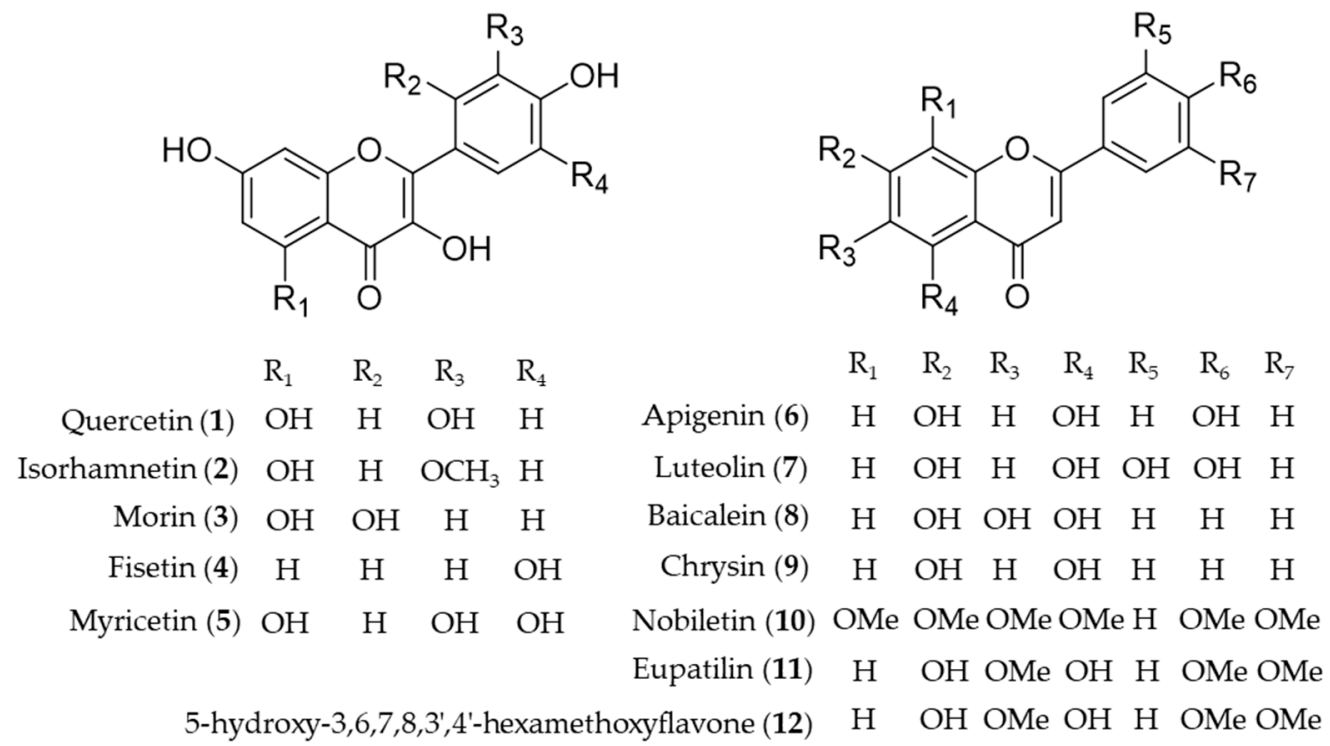

Figure 3. Structures of the flavonoid natural products (1-12).

Another bioactive O-methylated flavone isolated from the heartwood of Dalbergia odorifera, 6,4'-dihydroxy-7-methoxyflavanone (13) was also proposed as an antioxidative and anti-inflammatory HO-1 inducer in mouse hippocampal HT22 cells and BV2 microglia cells [126]. Ampelopsin (14), a flavonoid abundant in Rattan tea (Ampelopsis grossedentata), was investigated as a potent antioxidant and neuroprotective agent against $\mathrm{H}_{2} \mathrm{O}_{2}$-induced apoptosis in PC12 cells via upregulation of HO-1 expression [127]. Naringenin (15), a flavonone present in various species of citrus fruit, tomatoes and grapes, has anti-inflammatory and antiarthritic properties [128]. Dihydrofisetin (16) is a flavanonol, dose-dependently inhibited lipopolysaccharide-induced productions of $\mathrm{NO}$ and $\mathrm{PGE}_{2}$ in RAW 264.7 macrophage [129]. In addition, dihydrofisetin (16) inhibited the activation of MAPK pathway and phosphorylation of IKB- $\alpha$ whereas it upregulated the expression of HO-1 [129]. Sophoraflavanone G (17) and leachianone A (18) are anti-inflammatory components found in an oriental medicinal herb Sophora flavescens, and the compounds belong to a unique and rare class of prenylated flavonoid [130]. The induction of HO-1 by the prenylated flavonoids was identified as the key mechanism of the protective effect against glutamate toxicity in HT22 cells [131]. Sophoraflavanone G (17) was also isolated from another allied species, Sophora alopecuroides, and the prenylated flavonoid showed potential to treat some inflammatory diseases by targeting PI3K/Akt, JAK/STAT and Nrf2/HO-1 pathways [132]. Structures of the flavonoid natural products (13-18) are presented in Figure 4. 
<smiles>[R5]c1cc([C@H]2Oc3cc([R])c([R2])c([R3])c3C(=O)[C@H]2[R4])cc([R7])c1[R6]</smiles>

6,4'-Dihydroxy-7methoxyflavanone (13)

$\begin{array}{lllllll}\mathrm{R}_{1} & \mathrm{R}_{2} & \mathrm{R}_{3} & \mathrm{R}_{4} & \mathrm{R}_{5} & \mathrm{R}_{6} & \mathrm{R}_{7}\end{array}$

Ampelopsin (14) $\mathrm{OMe} \mathrm{OH} \quad \mathrm{H} \quad \mathrm{H} \quad \mathrm{H} \quad \mathrm{OH} \quad \mathrm{H}$

$\begin{array}{llllllllllll}\text { Naringenin (15) } & \mathrm{OH} & \mathrm{H} & \mathrm{OH} & \mathrm{H} & \mathrm{H} & \mathrm{OH} & \mathrm{H}\end{array}$

Dihydrofisetin(16) $\mathrm{OH} \quad \mathrm{H} \quad \mathrm{H} \quad \mathrm{OH} \quad \mathrm{OH} \mathrm{OH} \quad \mathrm{H}$<smiles>[R]c1cc(O)ccc1[C@H]1CC(=O)c2c(O)cc(O)c(C[C@@H](CC=C(C)C)C(=C)C)c2O1</smiles>

$\mathrm{OH}$

$\mathrm{OMe}$

Figure 4. Structures of the flavonoid natural products (13-18).

Catechins are flavan-3-ol compounds contained in tea as the most abundant phenolic chemical species that exert antioxidant and anti-inflammatory activity [133]. Among the flavonoids classified as catechins in tea, the major green tea catechin, epigallocatechin-3-gallate (19, EGCG) has been intensively investigated as it was discovered a HO-1 expression inducing agent that helps protect the neuron against oxidative stress-induced cell death [134], possibly block the pathogenic cycle of Sjögren's syndrome [135], inhibit inflammatory responses by suppressing the production of proinflammatory cytokines during the adipocyte-macrophage interaction [136], protect against contrast-induced nephropathy by amelioration of oxidative stress and inflammation [137] and mediate beneficial cardiovascular actions via anti-inflammatory actions in vascular endothelium [138]. Chalcones are one of the major classes of natural products with widespread distribution in plant foodstuff with interesting pharmacological activities [139]. Chemically they are characterized of open-chain flavonoids in which the two aromatic rings are joined by a three-carbon $\alpha, \beta$-unsaturated carbonyl system [140]. Compared to the relevance in nature, chalcones have been identified as a considerably large group of natural antioxidant and anti-inflammatory agents found in foodstuff or medicinal herbs. Lee et al. reported $\mathrm{H}_{2} \mathrm{O}_{2}$-induced cell death and ROS generation could be inhibited by HO-1 expression induction of butein (20) [141]. Based on the role of HO-1 in the development of obesity and insulin resistance, Wang et al. proved that butein (20) activates the p38 MAPK/Nrf2/HO-1 pathway to act as a potent inhibitor of adipose hypertrophy and inflammation in a diet-induced obesity mouse model [142]. 3-Deoxysappanchalcone (21, also known as isoliquiritigenin 2'-methyl ether) is a major bioactive component isolated from Caesalpinia sappan, commonly used herbal medicine for inflammation and to improve blood circulation [143,144]. The molecular mechanism by which 3-deoxysappanchalcone (21) exerts anti-inflammatory activity was identified as induction of HO-1 expression at the translational level via activating the AKT/mTOR pathway [145]. 3-Deoxysappanchalcone (21) also exhibited antioral cancer effects by HO-1 upregulation via a pathway involving MAP kinases, NF- $\mathrm{kB}$ and Nrf2 [146]. The mechanism of anti-inflammatory activity by $4,2^{\prime}, 5^{\prime}$-trihydroxy-4'-methoxychalcone (22) from Dalbergia odorifera was revealed as inducing the expression of anti-inflammatory HO-1 via the Nrf2 pathway to inhibit proinflammatory mediators such as COX-2 and iNOS [147]. Kil et al. suggested anti-inflammatory action of okanin (23) by virtue of its $\alpha-\beta$ unsaturated carbonyl functional group, reporting that the underlying mechanism is inhibition of NO production and iNOS expression via Nrf2-dependent HO-1 expression [148]. Cardamonin (24), a chalcone isolated from Alpinia katsumadai, has been investigated to prove anti-inflammatory mechanisms of cardamonin (24) is related to the decrease in the level of MDA, iNOS, COX-2, NF- $\mathrm{kB}$ and MAPK and induction of the HO-1 expression [149]. Structures of epigallocatechin-3-gallate (19) and the chalcones (20-24) are presented in Figure 5. 


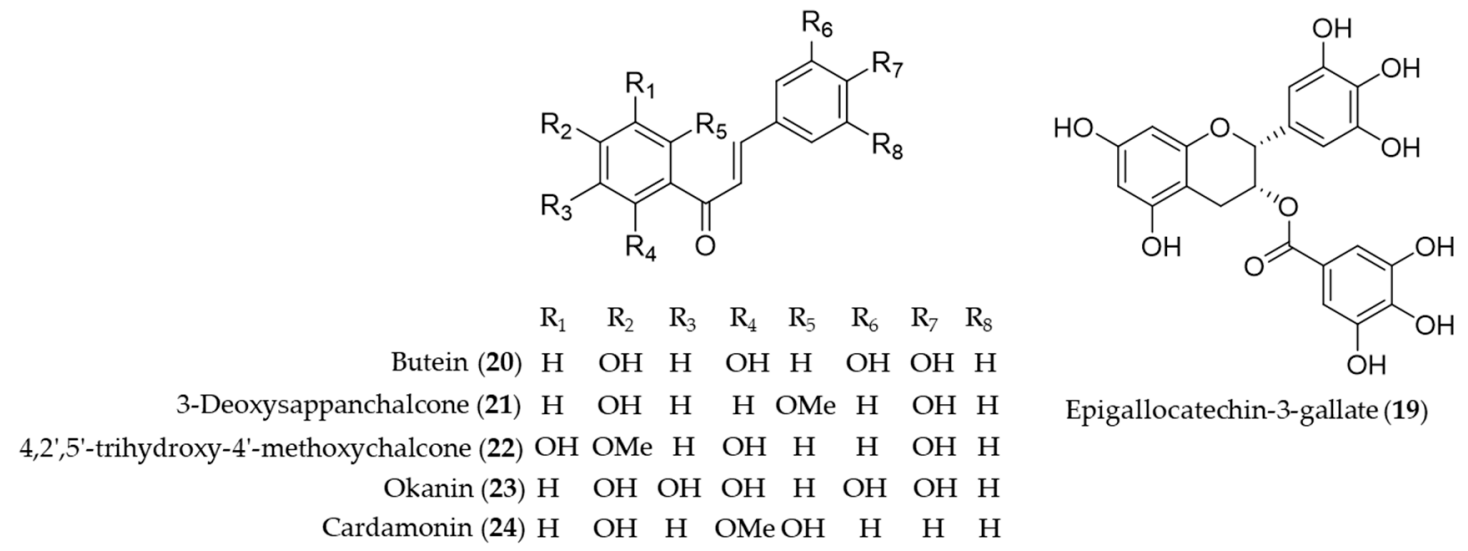

Figure 5. Structures of epigallocatechin-3-gallate (19) and the chalcones (20-24).

A prenylated chalcone, xanthohumol (25) is a major flavonoid contained in hop (Humulus lupulus), which is commonly used in beer brewing [150]. Lee et al. reported that xanthohumol (25) exerts anti-inflammatory activity through Nrf2-ARE signaling and upregulation of downstream HO-1, to ameliorate inflammatory responses in the brain [151]. Another prenylated chalcone, $7,9,2^{\prime}, 4^{\prime}$-tetrahydroxy-8-isopentenyl-5-methoxychalcone (26) isolated from Sophora flavescens was identified as an inducer of HO-1 expression, which in turn HO-1 and/or CO suppresses Th2 chemokine expressions induced by cytokines in human HaCaT cells [152]. Calycosin (27), an isoflavonoid from the Chinese medicinal herb Astragalus propinquus, induces Nrf2 that suppresses the expression of proinflammatory cytokines via p62/Nrf2-linked HO-1 induction in rheumatoid arthritis synovial fibroblasts [153]. The root of Pueraria lobata has been used for food and various medicinal purposes in traditional oriental medicine [154]. Puerarin (28, daidzein 8-C-glucoside), the main isoflavone glycoside found in Pueraria lobate, augments cellular antioxidant defense capacity through estrogen receptor-dependent HO-1 induction via the G $\beta 1 / \mathrm{PI} 3 \mathrm{~K} / \mathrm{Akt}-\mathrm{Nrf2}$ signaling pathway [155]. Puerarin (28) also alleviate the high glucose-induced acute endothelium-dependent vascular dysfunction in rat aortic rings via HO-1 expression induction [154]. Structures of the prenylated chalcones (25-26) and the isoflavones (27-28) are presented in Figure 6.<smiles>[R]c1cc(O)ccc1/C=C/C(=O)c1c(O)cc(O)c(CC=C(C)C)c1O</smiles>

Xanthohumol (25) $\mathrm{H}$

$7,9,2^{\prime}, 4^{\prime}$-tetrahydroxy-8 -isopentenyl-5-methoxychalcone (26) $\mathrm{OH}$

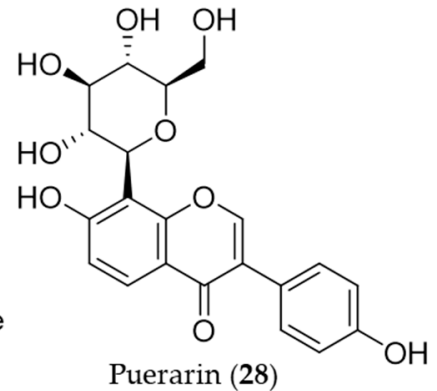

Calycosin $(27)$
Puerarin $(28$

Figure 6. Structures of the prenylated chalcones (25-26) and the isoflavones (27-28).

\subsection{Non-Flavonoid Phenolics}

Curcumin (29) is the main bioactive phenolic compounds present in turmeric, a spice with a variety of medicinal functions including antioxidant, anti-inflammatory [156], antimutagenic and antimicrobial $[157,158]$ activity. A number of research groups has reported the induction of HO-1 expression by curcumin (29) and the association with its antioxidant, anti-inflammatory activity, furthermore, the therapeutic and preventive potential for the related diseases since the first report on its HO-1 inducing activity [159]. The early investigations on induction of HO-1 by curcumin have markedly 
contributed to extending the understanding of the molecular mechanism of antioxidant effects exerted by HO-1. Curcumin (29) was identified as a potent inducer of HO-1 in vascular endothelial cells and the increased heme oxygenase activity is an important component in curcumin-mediated cytoprotection against oxidative stress [160]. Hill-Kapturczak et al. elucidated the mechanism of HO-1 induction by curcumin (29) was involved in the NF- KB pathway in human renal cells [161]. In the course of the study on antioxidant potential of curcumin (29), it was discovered that stimulation of ho- 1 gene activity could promote inactivation of the Nrf2-Keap1 complex, leading to increased Nrf2 binding to the resident ho-1 AREs [162]. McNally et al. discovered that PKC and p38 MAPK activity are required for full induction of HO-1 in the course of their study using curcumin (29) [163]. On the basis of the ethnopharmacological background [164-166], hepatoprotective effects by curcumin (29) pretreatment was involved in the doseand time-dependent induction of HO-1 [167]. Furthermore, the HO-1 induction exhibited inhibition of hepatitis $\mathrm{C}$ virus (HCV) replication along with AKT pathway inhibition [168]. The induction of HO-1 expression by curcumin (29) may protect human retinal pigment epithelial cells against oxidative stress by reducing ROS levels [169]. The recent study on the hepatoprotective potential of curcumin demonstrated that hepatic chronic inflammation could be ameliorated through the activation of HO-1 by curcumin (29) [170]. Cisplatin is a standard chemotherapeutic agent for solid malignances, in spite of the high incidence of side effects including ototoxicity [171]. Fetoni et al. reported that curcumin (29) treatment attenuated hearing loss induced by cisplatin via curcumin-mediated upregulation of HO-1 [172]. Curcumin (29) also protected SH-SY5Y cells against appoptosin-induced intrinsic caspase-dependent apoptosis by upregulating $\mathrm{HO}-1$, attenuating accumulation of intracellular heme and ROS [173]. Oregonin (30) is a glucose-conjugated diarylheptanoid, which shares the same structural backbone with curcumin (29). Oregonin (30) is known as the antioxidant and anti-inflammatory agent isolated from leaves of Alnus formosana [174], and the bioactivities are also involved in the induction of HO-1 [175]. A diarylheptanoid with cyclic structure, acerogenin A (31) from Japanese folk medicine Acer nikoense, showed neuroprotective effects and ROS reduction on glutamate-induced neurotoxicity by inducing the expression of HO-1 [176]. Structures of the diarylheptanoids (29-31) are presented in Figure 7.<smiles>COc1cc(/C=C/C(=O)CC(=O)/C=C/c2ccc(O)c(OC)c2)ccc1O</smiles>

Figure 7. Structures of the diarylheptanoids (29-31).

Caffeic acid phenethyl ester (32, CAPE) is a hydrophobic natural phenolic compounds with a variety of bioactivities found in a wide range of plants and honeybee propolis $[177,178]$. CAPE (32) is one of the first few natural products identified as an inducer of HO-1 expression [179], and a number of follow-up studies on CAPE (32) involving HO-1 induction and the health promoting-potential have been published. Wang et al. proposed the cytoprotective potential of CAPE (32) against menadione-induced oxidative stress in human umbilical vein endothelial cells (HUVEC) via upregulation of HO-1 by CAPE (32) [180]. Interestingly, caffeic acid, a potential metabolite of CAPE (32) with similar free radical scavenging ability, however, did not show any cytoprotective effect nor induce HO-1 in the study [180]. Morroni et al. suggested that CAPE (32) could potentially be considered as a promising neuroprotective agent against progressive neurodegenerative diseases, demonstrating administration of CAPE (32) counteracted oxidative stress accompanied by an induction of Nrf2 and HO-1 in a mouse model [181]. Kurauchi et al. also investigated the neuroprotective potential of CAPE (32) in vivo, examining the 
expression of HO-1 and the brain-derived neurotrophic factor [182]. High-level glucose-mediated oxidative stress could be attenuated by HO-1 induction by CAPE (32), and it may be useful in diabetes and other stress-induced pathological conditions [183]. CAPE (32) is putatively biosynthesized from caffeic acid and phenethyl alcohol, and it is not difficult to perform studies on chemical synthesis of derivatives and structure-activity relationship (SAR). Thus, SAR studies for enhancement of HO-1 induction using synthetic derivatives of CAPE (32) were reported as well [183-185]. A caffeic acid derivatives, caffeoylglycolic acid methyl ester (33) [89] contained in grains of Sorghum bicolor and 3-O-caffeoyl-1-methylquinic acid (34) [186] from bamboo leaves exerted anti-inflammatory effects by inducing HO-1 expression. Another type of caffeic acid ester derivative found in rosemary and other foodstuff, rosmarinic acid (35) [187] and a derivative isolated from Perilla frutescens, rosmarinic acid methyl ester (36) [188] also exert their antioxidant and anti-inflammatory action via induction of HO-1 expression. Salvianolic acid B (37) is a polyphenolic compounds isolated from Salvia miltiorrhiza (Danshen), a traditional oriental medicinal herb, which improves vascular function by inhibiting inflammatory responses and promoting endothelium-dependent vasodilation via induction of $\mathrm{HO}-1$ expression [189]. 2-Methoxycinnamaldehyde (38) is another phenylpropanoid natural product found in Cinnamomum cassia, which has been used as a spice and medicinal herb for inflammatory disorders. 2-Methoxycinnamaldehyde (38) possibly protects from myocardial I/R-injury due to antioxidant and anti-inflammatory action by HO-1 induction [190]. Hydroxytyrosol (39) is commonly found in olive oil and leaves with even stronger antioxidant potential than other natural phenolics but gallic acid [191]. The cytoprotective action against oxidative injury promotion and wound healing in vascular endothelial cells by hydroxytyrosol (39) could be explained with $\mathrm{Nrf2}$ activation and HO-1 induction [192,193]. Glycosides of phenylpropanoids, verbascoside (40), forsythoside B (41), echinacoside (42) and campneoside I (43) also reported as HO-1 inducing agents [194]. Structures of the phenolic natural products (32-43) are presented in Figure 8.
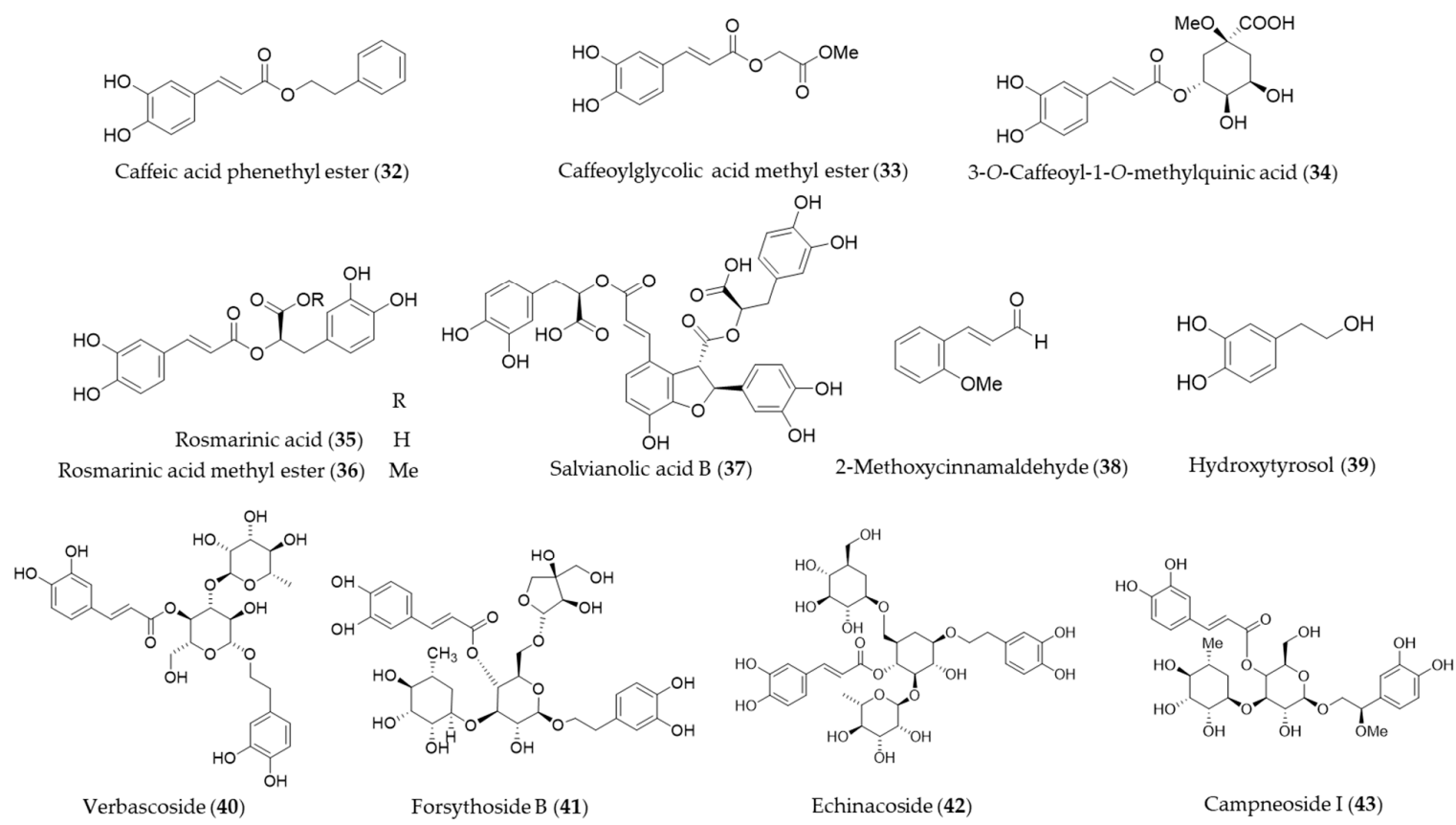

Figure 8. Structures of the phenolic natural products (32-43).

Coumarins are a group of phenolic natural products composed of fused benzene and $\alpha$-pyrone rings biosynthesized from cinnamic acid via ortho-hydroxylation, trans-cis isomerization of the side-chain double bond and lactonization [195]. Peucedanum japonicum has been used as a folk medicine in East Asia, and the antioxidant and antityrosinase active compounds were found in the leaf extract [196,197]. A coumarin derivative, pteryxin (44) isolated in P. japonicum was identified as HO-1 
inducing agent through Nrf2-ARE signaling [198]. Another coumarin derivative, corymbocoumarin (45) from Seseli gummiferum subsp. corymbosum was investigated for its anti-inflammatory effect through suppression of NF- $\mathrm{kB}$ signaling pathway and induction of HO-1 expression [95]. Resveratrol (46) is a polyphenolic stilbene that is frequently found in grapes and other food products, especially well-known as principal active component of red wine and grape peel $[199,200]$. The ability of resveratrol (46) to attenuate proinflammatory cytokine expression was investigated [201], and then potential of resveratrol (46) to induce HO-1 expression to exert antioxidant and anti-inflammatory action was suggested [202]. Resveratrol (46) increased the level of nuclear Nrf2/ARE reporter activity to induce HO-1 expression, which exerts a preventive effect on vascular occlusive diseases [175,203], potential neuroprotective action [204,205] and protective effect on cardiomyocyte apoptosis [206]. Piceatannol (47), structurally almost identical to resveratrol (46), with the exception of an additional hydroxyl group at the $3^{\prime}$-carbon is also a phytochemical inducer of HO-1 expression [207]. Brassicaphenanthrene A (48) isolated from common Brassica rapa (turnip) apparently does not look related with resveratrol, but brassicaphenanthrene A (48) and resveratrol (46) both belong to stilbenoid. Brassicaphenanthrene A (48) was also identified as a phytochemical inducer of HO-1 expression [208]. Structures of the phenolic natural products (44-48) are presented in Figure 9.

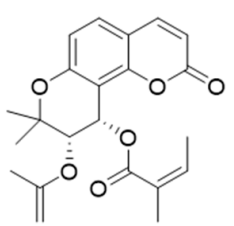

Pteryxin (44) Corymbocoumarin

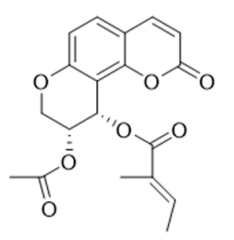

in $(45)$

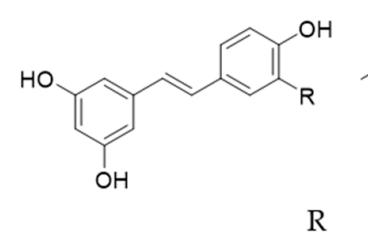

Resveratrol (46) H

Piceatannol (47) $\mathrm{OH}$

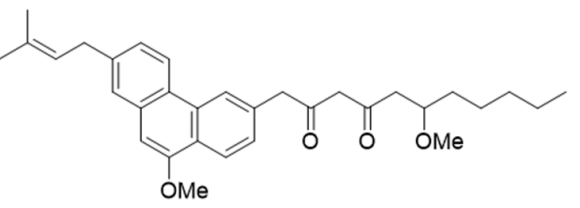

Brassicaphenanthrene A (48)

Figure 9. Structures of the phenolic natural products (44-48).

Aloin (49) is the major anthraquinone glycoside obtained from the Aloe species and exhibits anti-inflammatory and antioxidative activities via HO-1 induction and reduced NF-kB-luciferase activity [209]. A hydrophobic benzenoid isolated from Antrodia camphorate a mushroom used for pharmaceutical purpose, 4,7-dimethoxy-5-methyl-1,3-benzodioxole (50) has potential antiinflammatory activity via increased HO-1 expression that attenuated the LPS-induced proinflammatory factors and iNOS and TLR4 protein levels [210]. Another type of hydrophobic phenolic derivatives, 4-methoxydalbergione (51) and 4'-hydroxy-4-methoxydalbergione (52) from D. odorifera exhibited HO-1 induction to exert anti-inflammatory and cytoprotective effects [211]. Punicalagin (53), an ellagitannin polyphenol found in Punica granatum (pomegranates) with antioxidant activity had protective effects on $\mathrm{H} 9 \mathrm{c} 2$ cardiomyocytes from doxorubicin-induced toxicity [212] and human retinal pigment epithelium cells from UV radiation-induced oxidative damage [213] through activation of Nrf2/HO-1 signaling. Another gallic acid derivative from P. granatum, 1,2,3,4,6-pentagalloylglucose (54) is the pentagallic acid ester of glucose that also induces the expression of HO-1 in the PC12 cells and its regulation in the PC12 cells [214]. Rottlerin (55), isolated from Mallotus philippinensis, was originally reported to inhibit PKC $\delta$ [215], but it seems to induce upregulation of HO-1 via PKC $\delta$-independent pathway [216]. The bioactive polyphenols in agrimony, agrimonolide (56) and desmethylagrimonolide (57) induce HO-1 expression, which can be regulated partially by the blockade of p38 MAPK signaling pathway and inhibiting nuclear translocation of Nrf2 [217]. Lucidone (58) from the fruits of Lindera erythrocarpa, significantly induced HO-1 production and led to the increase of its production of biliverdin for inducing an antiviral interferon response and inhibiting HCV NS3/4A protease activity [218]. A phlorotannin found in an edible alga Ecklonia cava, eckol (59) attenuates oxidative stress by activating Nrf2-mediated HO-1 induction via extracellular regulated kinase (Erk) and PI3K/Akt signaling [219]. Malabaricone C (60) is known to exert a variety of pharmacological activities of nutmeg, and inhibits platelet-derived growth factor-induced proliferation and migration 
of aortic smooth muscle cells through induction of HO-1 [220]. The phenolic glucoside gastrodin (61), the bioactive component of Chinese herbal medicine Gastrodia elata, has been known to display antioxidant activity induce HO-1 expression to exert a cytoprotective role in the dopaminergic cell culture system [221], and alleviate $\mathrm{H}_{2} \mathrm{O}_{2}$-induced oxidative stress in mouse liver [222]. Structures of the phenolic natural products (55-61) are presented in Figure 10.<smiles>O=C1c2c(O)cccc2C(=O)C2([C@H](O)C(O)CO)C=C(CO)C=C(O)C12</smiles>

Aloin (49)

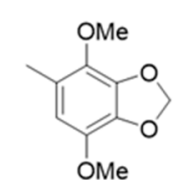

4,7-Dimethoxy-5-methyl -1,3-benzodioxole (50)

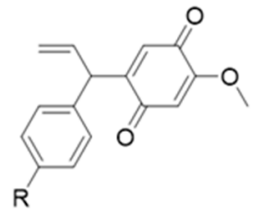

4-methoxydalbergione (51) $\mathrm{H}$

4'-Hydroxy-4methoxydalbergione (52) $\mathrm{OH}$<smiles>O=C(OOC(=O)c1cc(O)c(O)c(O)c1)OC(=O)OC(=O)c1cc(O)c(O)c(O)c1</smiles>

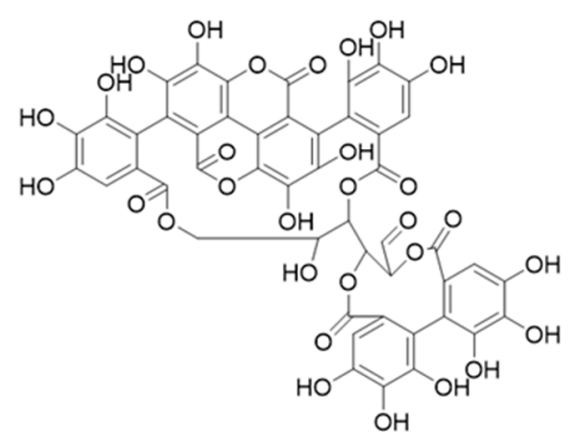

Punicalagin (53)<smiles>CC(=O)c1c(O)c(C)c(O)c(Cc2c(O)c3c(c(C(=O)/C=C/c4ccccc4)c2O)OC(C)(C)C=C3)c1O</smiles>

Rottlerin (55)<smiles>[R]c1ccc(CC[C@@H]2Cc3cc(O)cc(O)c3C(=O)O2)cc1</smiles>

$\mathrm{R}$

Agrimonolide (56) $\mathrm{OMe}$

Desagrimonolide (57) $\mathrm{OH}$<smiles>Oc1cc(O)cc(Oc2c(O)cc(O)c3c2Oc2cc(O)cc(O)c2O3)c1</smiles>

Eckol (59)<smiles>O=C(CCCCCCCCc1ccc(O)c(O)c1)c1c(O)cccc1O</smiles>

Malabaricone C (60)<smiles>CCC1=CC(=O)C(=C(O)C=Cc2ccccc2)C1=O</smiles>

Lucidone (58)

Figure 10. Structures of the phenolic natural products (55-61).

\section{Terpenoids and Steroids}

\subsection{Monoterpenes}

Thymoquinone (62) is an active constituent that belongs to monoterpenoid isolated from Nigella sativa that possesses alkylated benzoquinone structure [223]. Thymoquinone (62) induces HO-1 expression in $\mathrm{HaCaT}$ cells by activating Nrf2 through ROS-mediated phosphorylation of Akt and AMPK $\alpha$ [224]. Catalposide (63) belongs to a group of modified monoterpenes, iridoid glycoside that possesses antimicrobial, antitumoral and anti-inflammatory properties. Catalposide (63) isolated from 
the stem bark of Catalpa ovata is a potent inducer of HO-1 that mediates cytoprotection against oxidative damage [225]. Structures of the monoterpenes (62-63) are presented in Figure 11.<smiles>CC1=CC(=O)C(C(C)C)=CC1=O</smiles>

Thymoquinone (62)<smiles>O=C(O[C@@H]1[C@H]2O[C@@H]2[C@@H]2C(O[C@H]3O[C@H](CO)[C@@H](O)[C@H](O)[C@H]3O)OC=C[C@@H]12)c1ccc(O)cc1</smiles>

Catalposide (63)

Figure 11. Structures of the monoterpenes (62-63).

\subsection{Sesquiiterpenes}

Desoxonarchinol A (64), isolated form Nardostachys jatamansi, is an effective inducer of HO-1, which regulates neutrophil infiltration in acute pancreatitis via chemokine (C-X-C motif) ligand 2 inhibition [226]. Kim et al. investigated the antineuroinflammatory effects via upregulation of Nrf2/HO-1 signaling by desoxonarchinol A (64) along with another derivative narchinol B (65) [227]. Zerumbone (66) is a monocyclic sesquiterpene and the major active phytochemical compound in Zingiber zerumbet [228] Zerumbone (66) is known to have antioxidant activity, anti-inflammation, immunomodulatory effect and anticancer activity [11], and Leung et al. suggested the protective mechanisms of zerumbone (66) on acute lung injury were exerted via upregulation of $\mathrm{Nrf2} / \mathrm{HO}-1$ signaling [229]. Shin et al. reported topical application of zerumbone (66) onto dorsal skin of hairless mice induces activation of $\mathrm{Nrf2} / \mathrm{HO}-1$ expression that provides chemopreventive effects on mouse skin carcinogenesis [230]. Cyperus rotundus has been used as traditional folk medicine for the treatment of inflammatory diseases, and the possible anti-inflammatory mechanism is, at least, due to HO-1 induction, in which sesquiterpenes such as nootkatone (67) and valencene (68) play a crucial role [231]. Pulchellamin G (69) is an amino acid-sesquiterpene lactone conjugate isolated from Saussurea pulchella, and the anti-inflammatory activity was associated with induction of HO-1 expression [232]. Jeong et al. suggested the $\alpha$-methylene- $\gamma$-butyrolactone moiety in dehydrocostus lactone (70) is crucial for cytoprotective HO-1 expression through activation of the Nrf2 [233], and Park et al. suggested that dehydrocostus lactone (70) might be useful for the treatment of sepsis through the mechanism [234]. Eupatolide (71), a sesquiterpene lactone from Inula britannica could suppress platelet-derived growth factor-induced proliferation and migration of vascular smooth muscle cells (VSMCs) through HO-1 induction via the ROS-Nrf2 pathway and may be a potential HO-1 inducer for preventing or treating vascular diseases [235]. Nardochinoid B (72) is a terpene composed of thirty carbons and a nitrogen, but not a triterpene. The putative biosynthetic pathway of nardochinoid B (72) is dimerization of nardosinane sesquiterpenes, and it exerts significant anti-inflammatory activity [236]. The mechanism of anti-inflammatory action by nardochinoid B (72) was revealed as activating the Nrf2/HO-1 pathway [237]. Structures of the sesquiterpenes (64-72) are presented in Figure 12. 
<smiles>[R]C1=CC2=CC=CC(O)[C@H]2[C@@H](C)C1</smiles>

$\mathrm{R}$

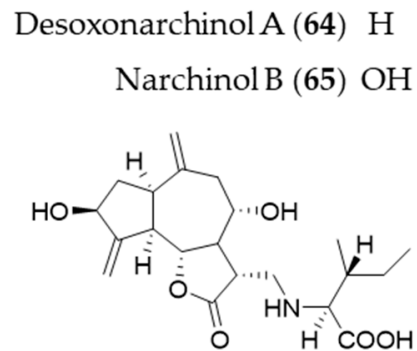

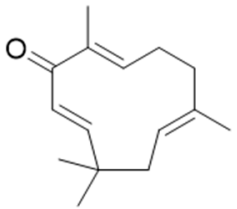

Zerumbone (66)<smiles>C=C(C)[C@@H]1CCC2=CC(=O)CC(C)C2(C)C1</smiles>

Nootkatone (67)<smiles>C=C(C)C1CCC2=CCC[C@H](C)[C@]2(C)C1</smiles>

Valencene (68)

Pulchellamin G (69) Dehydrocostus lactone (70) Eupatolide (71)<smiles></smiles>

Nardochinoid B (72)

Figure 12. Structures of the sesquiterpenes (64-72).

\subsection{Diterpenes}

A diterpenoid isolated from the sap of Podocarpus totara, totarol (73) is known for its potent antimicrobial activity [238]. The neuroprotective activity of totarol (73) by increased Akt and GSK-3 $\beta$ phosphorylation, Nrf2, HO-1 expressions was investigated in a model of acute cerebral ischemic injury in the rat [239]. Another phenolic diterpene, carnosol (74), could target ho-1 to induce HO- 1 expression, and increased the nuclear levels of Nrf2 [240,241]. The bioactive diterpene, palbinone (75) in Paeonia suffruticosa, which has been traditionally employed for vitalizing blood circulation and alleviating liver and inflammatory diseases could induce HO-1 expression in the hepatic cells [242]. Oridonin (76) is an ent-kaurene diterpene with an immunosuppressive effect isolated from Isodon serra [243]. According to the study performed by $\mathrm{Hu}$ et al., oridonin (76) had a distinct effect on promoting CD4+/CD25+ Treg differentiation and modulating Th1/Th2 balance, and this effect may be achieved via inducing the anti-inflammatory target HO-1 [244]. Andrographolide (77) is a well-known diterpene, characterized of labdane diterpenoid with a five-membered unsaturated lactone moiety, isolated from an oriental medicinal herb Andrographis paniculata [245]. Yu et al. suggested that stimulation of Nrf2-dependent HO-1 expression is involved in the suppression of TNF- $\alpha$-induced ICAM-1 expression exerted by andrographolide (77) [246]. Another diterpenoid with a five-membered lactone isolated from Euphorbia fischeriana, 17-hydroxy-jolkinolide B (78) could inhibit COX-2, iNOS in a concentration-dependent manner. These inhibitory effects were caused by suppression of MAPK phosphorylation and NF- $\kappa B$ activation and HO-1 induction [247]. Dihydroartemisinin (79) is isolated from Artemisia annua that has prominent immunomodulatory activity that regulates the Th/Treg balance by inducing activated CD4+ T cell apoptosis via HO-1 induction in mouse models of inflammatory bowel disease [248]. Rebaudioside A (80) is a commercially used natural sweetener from Stevia rebaudiana, which has been discovered as a potential candidate hepatoprotective agent that activate Nrf2/ARE, and the expression of HO-1 and NAD(P)H quinone oxidoreductase 1 (NQO1) [249]. Structures of the diterpenes (73-80) are presented in Figure 13. 


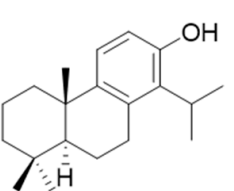

Totarol (73)

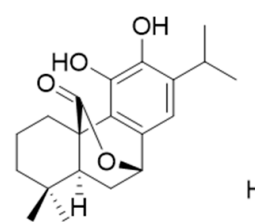

Carnosol (74)

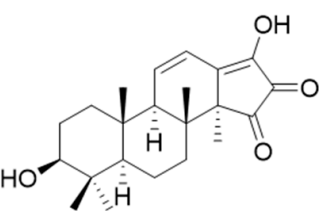

Palbinone (75)

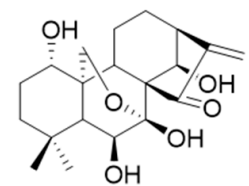

Oridonin (76)

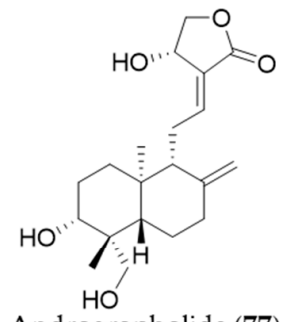

Andrographolide (77)

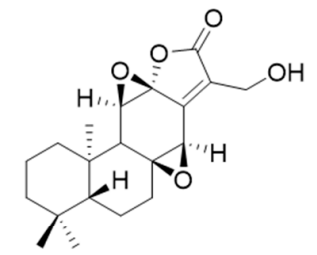

17-Hydroxy-jolkinolide B (78)

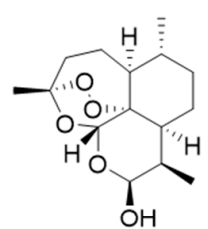

Dihydroartemisinin (79)

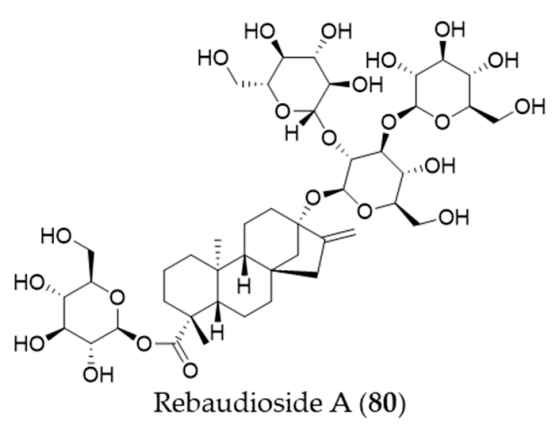

Figure 13. Structures of the diterpenes (73-80).

\subsection{Titerpenes}

Celastrol (81) is a triterpene isolated from the plant family Celastraceae and these plants have been used in traditional Chinese medicine for their anti-inflammatory property [250]. Yu et al. investigated the ability of celastrol (81) to attenuate hypertension-induced inflammation and oxidative stress in VSMCs via HO-1 induction [251]. The celastrol-mediated HO-1 expression may reduce HIV-1 Tat-induced neuroinflammatory responses [252], HCV replication [253] and macrophage M1 polarization [254]. Jeong et al. discovered an anti-inflammatory phytochemical, an ursane-type triterpene, 23-hydroxyursolic acid (82,33, 23-dihydroxyurs-12-en-28-oic acid) from flowered fruit-spike of Prunella vulgaris, which increased the expression of HO-1 in a dose-dependent manner in human liver-derived HepG2 cells [255]. Another ursane-type triterpene from Cucurbita pepo was also found as an inducer of HO-1 expression [256]. The fruiting bodies of Ganoderma lucidum (commonly known as the Reishi mushroom) are widely used in China, Japan and Korea as a valuable crude drug, especially in the treatment of chronic hepatitis, nephritis, hepatopathy, neurasthenia, arthritis, bronchitis, asthma, gastric ulcer and insomnia [257]. Lanostane-type (tetracyclic) triterpenes were identified as phytochemicals responsible for the anti-inflammatory activity inducing HO-1 expression [258]. Glycyrrhizin (83) is a triterpene glycoside, which is responsible for sweet taste and pharmacological activity of Glycyrrhiza glabra (licorice) [259]. Kim et al. proposed that glycyrrhizin (83) reduces high mobility group box 1 (HMGB1) secretion by p38/Nrf2-dependent induction of HO-1, which may prevent sepsis [259]. Mou et al. demonstrate that glycyrrhizin (83) protects human melanocytes from $\mathrm{H}_{2} \mathrm{O}_{2}$-induced oxidative damage via the Nrf2-dependent induction of $\mathrm{HO}-1$, providing evidence for the application of glycyrrhizin (83) in the treatment of vitiligo [260]. Another triterpene glycoside chiisanoside (84) isolated from Acanthopanax sessiliflorus showed a hepatoprotective effect via an antioxidative effect and inflammatory suppression in NF- $\mathrm{kB}$ and activation of Nrf2/HO-1 signaling [261]. Structures of the triterpenes (81-84) are presented in Figure 14. 


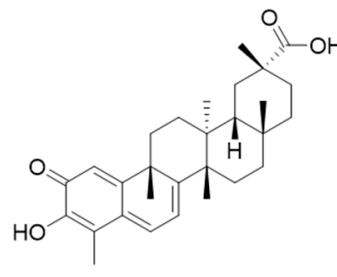

Celastrol (81)

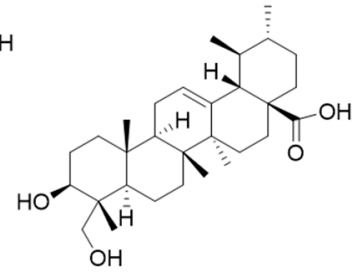

23-Hydroxyursolic acid (82)

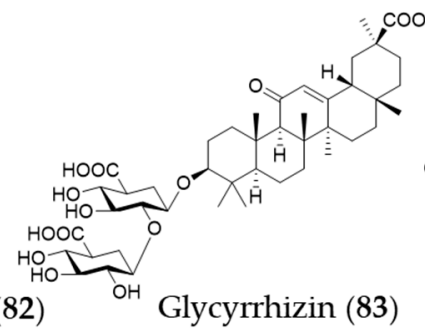

Glycyrrhizin (83)

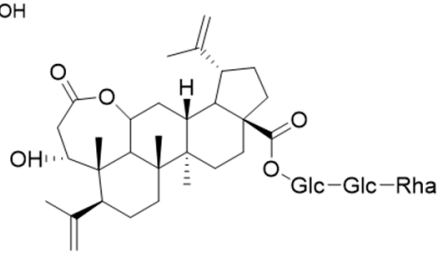

Chiisanoside (84)

Figure 14. Structures of the triterpenes (81-84).

\subsection{Steroids}

Withaferin A (85) is one of bioactive steroidal phytochemicals, withnolides, which is responsible for the bioactivities of Withania somnifera, also known as "Ashwagandha", "Indian ginseng" or "winter cherry", a frequently used medicinal herb in Ayurvedic medicine (Indian traditional medicine) [262]. Withaferin A (85) induces HO-1 expression in endothelial cells via upregulation and increased nuclear translocation of Nrf2 in a time- and concentration-dependent manner [262]. Ginsenosides are unique steroid glycosides and triterpene saponins that are present exclusively in the genus Panax [263]. More than 150 natural ginsenosides have been reported [264], and they share a common tetracyclic structure, but the number and position of sugar or hydroxyl moiety may vary among ginsenosides [265]. Ginsenoside $\mathrm{Rb} 1$ (86) was reported to have a protective effect against oxidative stress by increasing HO-1 expression through an estrogen receptor-related PI3K/Akt/Nrf2-dependent pathway in human dopaminergic cells [266]. Ginsenoside Rg18 (87) attenuated neuroinflammation in BV2 microglia and amyloid- $\beta$-induced oxidative stress in SH-SY5Y neurons via Nrf2/HO-1 induction [267]. Another type of steroidal glycoside, furotrilliumoside (88), isolated from Trillium tschonoskii also upregulated HO-1 expression via Nrf2 that might act as a natural agent to treat inflammatory diseases [268]. Structures of the the steroids (85-88) are presented in Figure 15.

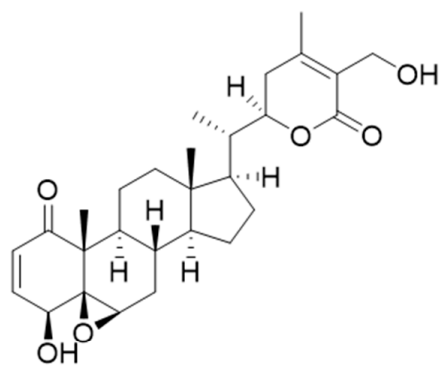

Withaferin A (85)

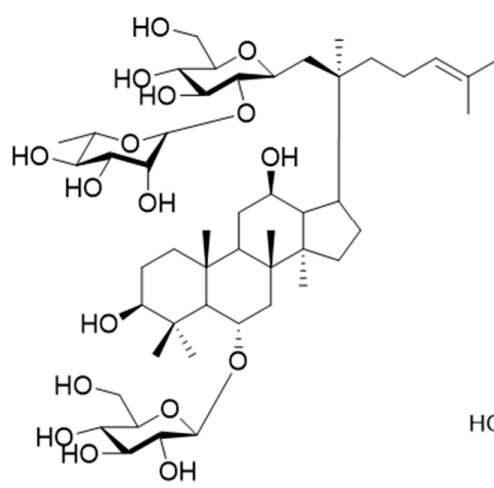

Ginsenoside Rg18 (87)

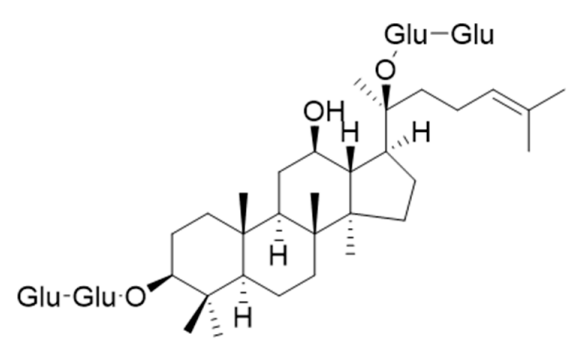

Ginsenoside Rb1 (86)

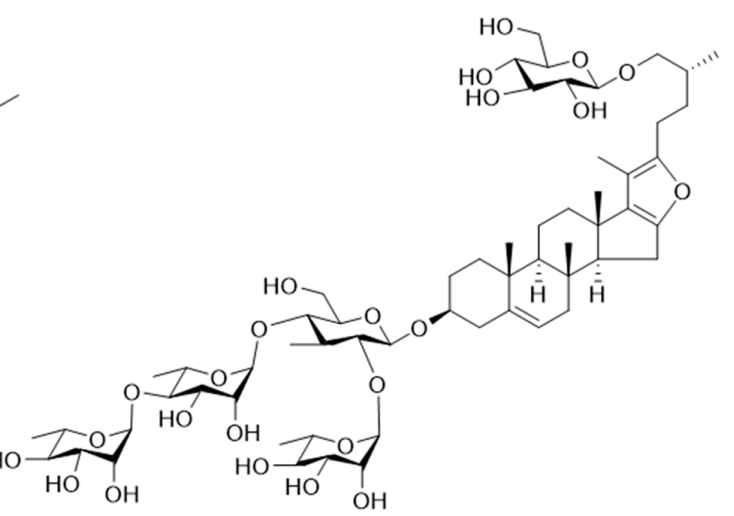

Furotrilliumoside (88)

Figure 15. Structures of the steroids (85-88). 


\subsection{Other Natural Products from Mevalonate Pathway}

Astaxanthin (89) is a blood-red pigment that belongs to xanthophyll, which is present in many aquatic organisms such as krill, algae, shrimp, salmon and so on [269]. It is produced commercially from large cultures of microalga, Haematococcus pluvialis as an ingredient for dietary supplements and fish feeds [176]. Astaxanthin (89) could also ameliorate the chemotherapeutic drug, doxorubicin-induced liver injury through the Keap1/Nrf2/HO-1 pathway in mice [270]. Solanesol (90) is classified as a nonaisoprenoid, and it is known to be present in tobacco, potato and tomato [271]. Yao et al. suggested that the anti-inflammatory activity of solanesol (90) also comes from induction of expression of $\mathrm{HO}-1$ via p38 and Akt and suppression of proinflammatory cytokines production [272]. Structures of astaxanthin (89) and solanesol (90) are presented in Figure 16.

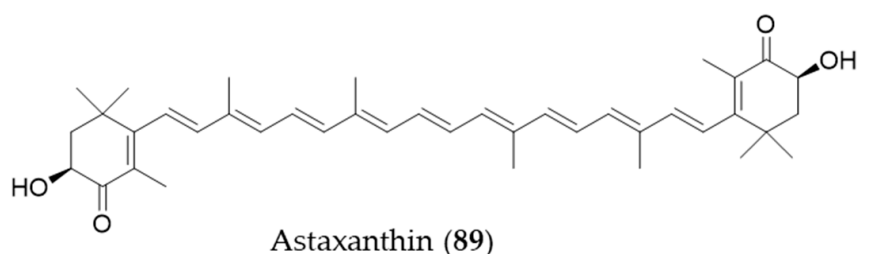

Astaxanthin (89)

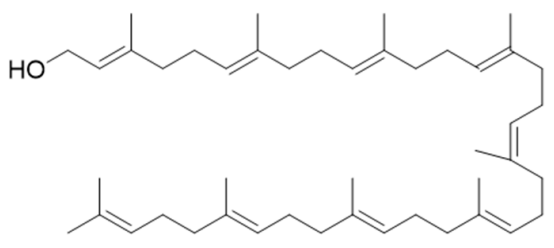

Solanesol (90)

Figure 16. Structures of astaxanthin (89) and solanesol (90).

\section{Lipids}

The bioactive natural products with $\mathrm{HO}-1$ induction that belong to lipids were small in number. Interestingly, they were all unsaturated fatty acids or fatty acid derivatives. One of the omega-3 essential fatty acids, eicosapentaenoic acid (91, EPA) protects against $\mathrm{H}_{2} \mathrm{O}_{2}$-induced oxidative stress in endothelial cells by activating Nrf2 and inducing HO-1 expression [273]. Another omega-3 fatty acid, docosahexaenoic acid (92, DHA) also increased HO-1 expression in U937 cells via activation of ERK1/2 and increased Nrf-2 binding to ARE [274]. The major alkamides dodeca-2E,4E,8Z,10Z(E)-tetraenoic acid isobutylamides $(\mathbf{9 3}, \mathbf{9 4})$, isolated from Echinacea purpurea have potential for prevention of acute hepatic injury through JNK pathway-mediated HO-1 expression [275]. Ethyl linoleate (95) from garlic was also found to attenuate proinflammatory cytokine production by inducing HO-1 [276]. Structures of the lipid natural products (91-95) are presented in Figure 17.

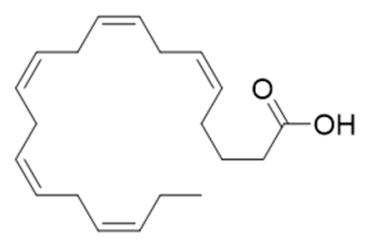

Eicosapentaenoic acid (91)

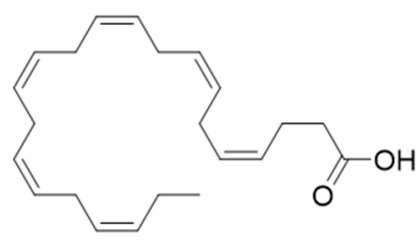

Docosahexaenoic acid (92)<smiles>C/C=C/C=C/CC/C=C/C=C/C(=O)NCC(C)C</smiles>

Dodeca-2E,4E,8Z,10Z-tetraenoic acid isobutylamide (93)<smiles>C/C=C/C=C/CC/C=C/C=C/C(=O)NCC(C)C</smiles><smiles>CCCCC/C=C\C/C=C\CCCCCCCC(=O)OCC</smiles>

Ethyl linoleate (95)

Dodeca-2E,4E,8Z,10E-tetraenoic acid isobutylamide (94)

Figure 17. Structures of the lipid natural products (91-95). 


\section{Lignan}

Sesamin (96) and its stereoisomer episesamin (97) are bioactive lignans found in sesame oil [277]. They are readily metabolized by cytochrome P-450 to yield a series of metabolites, and the metabolites were screened for antioxidant potential [278]. The most potent antioxidant metabolite, SC-1 (98) was capable of protecting against oxidative stress-induced neuronal cell death in part through induction of HO-1 via Nrf2/ARE activation [278]. Honokiol (99), a phenolic lignan originally isolated from Magnolia obovate, significantly inhibited cyclosporine A-induced and Ras-mediated survival of renal cancer cells through the downregulations of the vascular endothelial growth factor (VEGF) and HO-1 [279]. It implies honokiol (99) may help to prevent tumor-promoting effects of an immunosuppressant drug, cyclosporine A in transplant patients [279]. Another phenolic lignan isolated from Magnolia officinalis, magnolol (100) inhibits Porphyromonas gingivalis LPS-induced inflammation in macrophages, which is mediated by HO-1 activation, and thereby it is plausible for treatment of periodontitis [280]. Saururus chinensis, an oriental medicinal herb has been used to treat jaundice, pneumonia, edema, fever and several inflammatory diseases [281]. Sauchinone (101), a diastereomeric lignan isolated from Saururus chinensis protects vascular inflammation [282] and significantly inhibit NO production and inflammatory mediators expression [283] via HO-1 induction. Another lignan isolated from Saururus chinensis, saucerneol D (102) suppresses LPS-induced activation of dendritic cells through the induction of HO-1 [284]. Lariciresinol (103), isolated from Rubia philippinensis, has a dimeric structure of a phenylpropanoid with a core structure of tetrahydrofurano ring, and exerts potent antioxidant activity [285]. The antioxidant potential of lariciresinol (103) is due to the increased transcriptional and translational levels of antioxidant enzymes by activating Nrf2-mediated HO-1 induction via p38 signaling [286]. Structures of the lignan natural products (96-103) are presented in Figure 18.
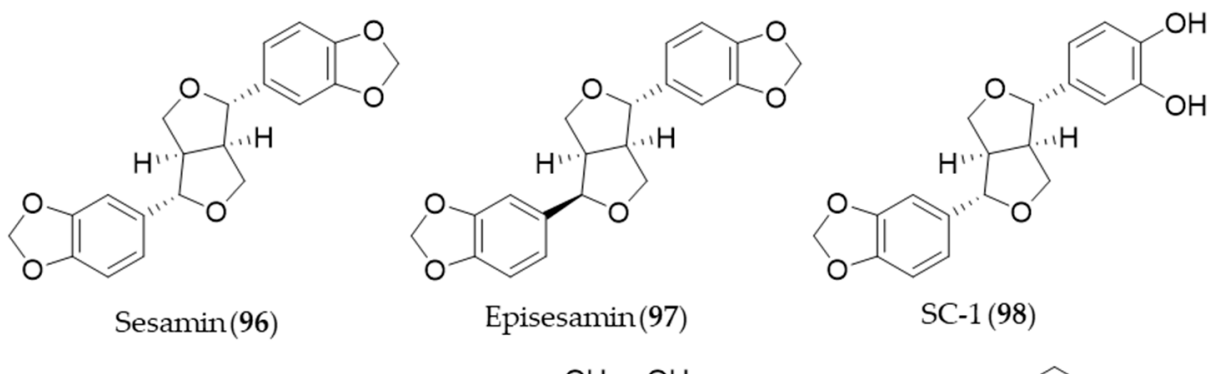

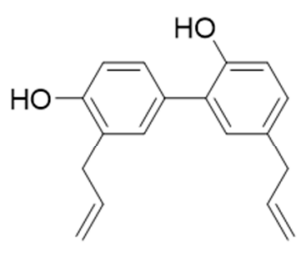

Honokiol (99)

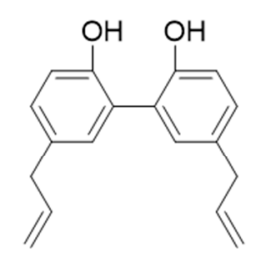

Magnolol(100)

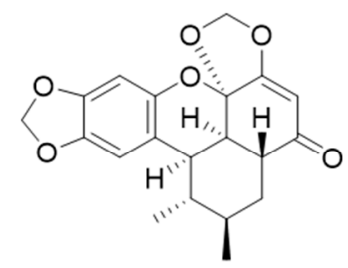

Sauchinone(101)<smiles>COc1ccc([C@@H](O)[C@@H](C)Oc2ccc([C@@H]3O[C@@H](c4ccc5c(c4)OCO5)[C@H](C)[C@H]3C)cc2OC)cc1OC</smiles>

SaucerneolD (102)<smiles>COc1cc(C[C@@H]2CO[C@@H](c3ccc(O)c(OC)c3)[C@H]2CO)ccc1O</smiles>

Lariciresinol(103)

Figure 18. Structures of the lignan natural products (96-103).

\section{Amino Acid Derivatives}

L-Glutamine (104) reduced colonic damage in colitis by the mechanism of the protection associated with HO-1 induction effects, which were documented by the decrease in NF- $\mathrm{kB}$ expression, MDA, 
and caspase-3 levels and concurrent increase in GSH levels and HO-1 overexpression in the colonic tissue [287]. Melatonin (105) is a neurohormone derived from an amino acid tryptophan and released by the pineal gland to regulate the circadian rhythm [288]. In vertebrates, melatonin (105) is produced in darkness, by the pineal gland [289], but it is also ingested from plant foodstuff such as bananas, grapes, rice, herbs, plums and olive [290]. Beside the circadian regulation, melatonin (105) can prevent damages of cells from oxidative stress, especially involved with neurodegeneration in aging and Alzheimer's disease [291,292]. Clapp-Lilly et al. suggested that melatonin (105) induced redox active iron and HO-1 immunoreactivity that it may be a potential therapeutic agent in the prevention of oxidative stress associated with A $\beta$ and Alzheimer's disease [293]. The HO-1 induction by melatonin (105) also potentiates the neuroprotective effect of resveratrol against oxidative injury [294], and inhibits type 1 interferon signaling of TLR4 in hepatic ischemia/reperfusion [295]. Garlic yields a variety of organosulfuric compounds with health benefits [296]. An unique amino acid derivative present in raw garlic, $S$-allylcysteine (106) provided potent anti-inflammatory, antioxidative and mucosa protective effects against nonsteroidal anti-inflammatory drug (NSAID)-induced damages via induction of HO-1 [296]. Structures of the amino acid derivatives (104-106) are presented in Figure 19.<smiles>NC(=O)CCC(N)C(=O)O</smiles>

L-Glutamine (104)<smiles>COc1ccc2[nH]cc(CCNC(C)=O)c2c1</smiles>

Melatonin (105)<smiles>C=CCSCC(N)C(=O)O</smiles>

S-Allylcysteine (106)

Figure 19. Structures of the amino acid derivatives (104-106).

\section{Alkaloids and Nitrogen-Containing Natural Products}

Piperine (107) is a major alkaloid present in black pepper (Piper nigrum), which is known to possess pharmacological benefits, such as antimicrobial, antipyretic and anti-inflammatory effects [173]. The expression of HO-1 by piperine (107) is mediated by both JNK pathway and Nrf2, and the expression inhibits cisplatin-induced apoptosis [297]. Sinomenine (108), an alkaloid isolated from an oriental medicinal herb Sinomenium acutum, which has been used to treat inflammatory diseases including rheumatism and arthritis [298]. Sinomenine (108) pretreatment was able to induce HO-1 expression in donor livers in a dose dependent manner and it protected the liver graft from cold ischemia/reperfusion injury [299]. Higenamine (109) is a bioactive alkaloid in Aconitum carmichaeli, which has been used as a heart stimulant and anti-inflammatory agent in traditional oriental medicine [300]. Higenamine (109) promotes M2 macrophage activation and reduces Hmgb1 expression dependent on HO-1 induction and then promotes locomotor function after spinal cord injury [301]. Camptothecin (110) is a potent anticancer alkaloid isolated from Camptotheca acuminate [302] as a strong inhibitor of the DNA-replicating enzyme topoisomerase I [303]. Jayasooriya et al. suggested camptothecin (110) also inhibits the invasion of cancer cells accompanied by suppression of MMP-9 and VEGF production by suppressing the PI3K/Akt-mediated NF- $\mathrm{kB}$ pathway and enhancing the Nrf2-dependent HO-1 pathway [304]. Berberine (111) is an isoquinoline alkaloid from Coptis chinensis with pharmacological effects such as hypoglycemic, antioxidant and anti-inflammatory activity [305-307]. Berberine (111) can protect against methotrexate-induced liver injury from oxidative stress and apoptosis, possibly through upregulating the Nrf2/HO-1 pathway and PPAR $\gamma$ [308]. Capsaicin (112) is a unique alkaloid that provides spicy flavor of the fruit of the genus Capsicum (peppers) [309]. Joung et al. found that capsaicin (112) induced expression of HO-1 that resulted in a transient increase in the phosphorylation of Akt and subsequently nuclear translocation of Nrf2, enhancing its binding to ARE [310]. Kim et al. suggested the anti-inflammatory activity of capsaicin (112) and another derivative, dihydrocapsaicin (113) is exerted through NO production and iNOS expression and induction of HO-1 [311]. Matrine (114) is a quinolizidine alkaloid isolated from S. flavescentis, and possesses 
antioxidant, anti-inflammatory and antitumor activity [312-314]. Matrine (114) may alleviate early brain injury after experimental subarachnoid hemorrhage in rats possibly via PI3K/Akt-mediated NF-kB inhibition and Keap1/Nrf2-dependent HO-1 induction [315]. Cordycepin, a bioactive adenosine derivative, which was found in Cordyceps militarisa known as a rare Chinese caterpillar fungus, has beneficial activity to circulatory, immune, respiratory and glandular systems [316]. Cordycepin exhibited protective effects on $\mathrm{N}$-nitrosodiethylamine-induced hepatocellular carcinomas via the $\mathrm{PI3K} / \mathrm{Akt} / \mathrm{mTOR}$ and Nrf2/HO-1/NF-KB pathway in mice [317]. Chabamide (115) is a dimeric piperine initially discovered from Piper chaba [318]. Ngo et al. isolated a series of alkaloid with inhibitory activity on LPS-induced NO production in RAW264.7 from Piper nigrum (black pepper) [319]. Among the alkaloids, chabamide (115) especially inhibited LPS-induced NO production in bone marrow-derived macrophages, via inducing HO-1 expression at the transcriptional level and inducing nuclear translocation of Nrf2 [319]. Piperlongumine (116), an alkaloid from Piper longum (long pepper) was found to induce apoptosis of human breast cancer MCF-7 cells mediated by upregulation of HO-1 expression [320]. Lu et al. reported that HO-1 induction of piperlongumine (116) may also result in the inhibitory effect on Zika virus replication [321]. Six isosteroid alkaloids isolated from Fritillaria cirrhosa bulbus, a Chinese folk herb with antitussive, expectorant, antiasthma and anti-inflammatory properties demonstrated to protect murine RAW264.7 macrophages against cigarette smoke-induced oxidative stress [322]. They were cevanine or jervine type alkaloids and decreased the generation of ROS and increased the level of GSH via Nrf2 nuclear translocation and HO-1 expression via activating Nrf2 signaling pathway [322]. Peiminine (117, also known as verticinone) has long been studied as a major bioactive component of anti-inflammatory Chinese medicinal herbs Fritillaria sp. [323]. Luo et al. reported peiminine (117) ameliorates murine osteroarthritis anti-inflammatory activity induced by inhibition of Akt phosphorylation, the nuclear transfer of NF- $\mathrm{kB}$ and activated Nrf2/HO-1 signaling pathways [324]. Structures of the alkaloids and nitrogen-containing natural products (107-117) are presented in Figure 20.

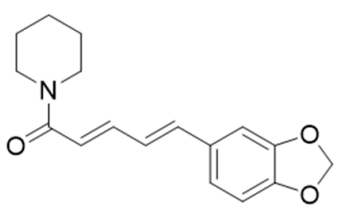

Piperine (107)

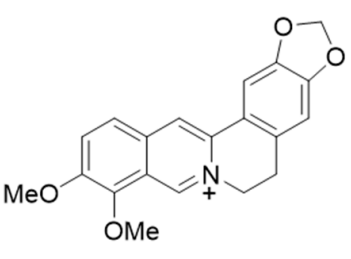

Berberine (111)

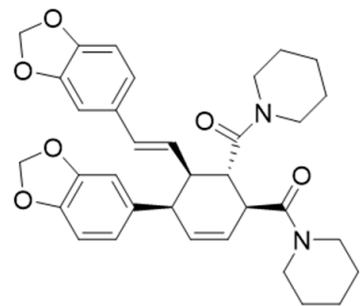

Chabamide (115)

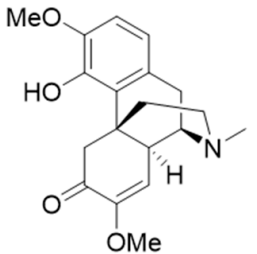

Sinomenine (108)

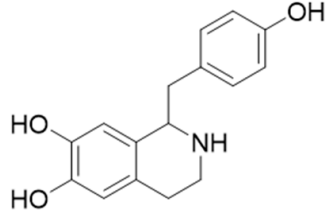

Higenamine (109)<smiles>CCCCCCCCCCCCC(=O)NCc1ccc(O)c(OC)c1</smiles><smiles>COc1cc(CNC(=O)CCCCCCC(C)C)ccc1O</smiles>

Dihydrocapsaicin (113)

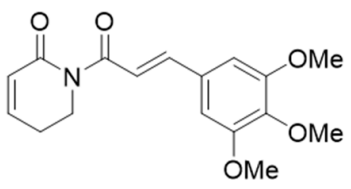

Piperlongumine (116)<smiles>CC[C@@]1(O)C(=O)OCc2c1cc1n(c2=O)Cc2cc3ccccc3nc2-1</smiles>

Campothecine (110)

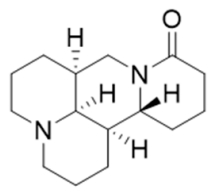

Matrine (114)

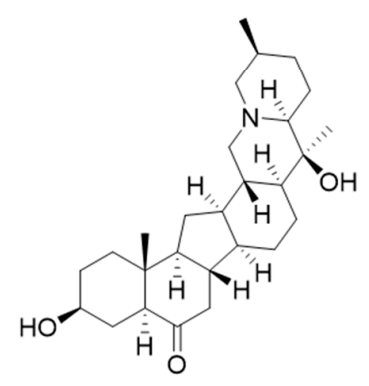

Peiminine (117)

Figure 20. Structures of the alkaloids and nitrogen-containing natural products (107-117). 


\section{Conclusions}

Global life expectancy has been increased in modern times, but healthy life expectancy has not been so, as most people suffer from chronic diseases, metabolic syndromes, degenerative brain diseases or cardiovascular diseases in their old age. However, a number of investigations suggest a healthy lifestyle including moderate exercise, a balanced diet and avoiding stress may improve health, delay the aging process, prevent chronic diseases and eventually increase healthy life expectancy. Adequate intake of antioxidant supplements may synergistically work to prevent those diseases as the diseases are mostly resulted from the accumulation of oxidative stress [325]. HO-1 plays a pivotal role in the antioxidant and anti-inflammatory system in humans, and it is possibly modulated by a variety of natural products in edible sources as we discussed so far. The natural products from edible sources might be promising sources of safe and effective HO-1 inducing agents that help our body protect from the chronic diseases.

Author Contributions: D.H., S.H.S., and J.-S.B. wrote the manuscript. J.-S.B. supervised the research. All authors have read and agreed to the published version of the manuscript.

Funding: This work was supported by the National Research Foundation of Korea (NRF) grant funded by the Korea government (MSIT; NRF-2020R1A2C1004131, 2019R1F1A1051041), and by Gyeongnam Technopark grant funded by Gyeongsangnam-do, Korea.

Conflicts of Interest: The authors declare that there is no conflict of interest.

\section{References}

1. Tenhunen, R.; Marver, H.S.; Schmid, R. The enzymatic conversion of heme to bilirubin by microsomal heme oxygenase. Proc. Natl. Acad. Sci. USA 1968, 61, 748-755. [CrossRef] [PubMed]

2. Funes, S.C.; Rios, M.; Fernandez-Fierro, A.; Covian, C.; Bueno, S.M.; Riedel, C.A.; Mackern-Oberti, J.P.; Kalergis, A.M. Naturally Derived Heme-Oxygenase 1 Inducers and Their Therapeutic Application to Immune-Mediated Diseases. Front. Immunol. 2020, 11, 1467. [CrossRef] [PubMed]

3. Choi, A.M.; Alam, J. Heme oxygenase-1: Function, regulation, and implication of a novel stress-inducible protein in oxidant-induced lung injury. Am. J. Respir. Cell. Mol. Biol. 1996, 15, 9-19. [CrossRef] [PubMed]

4. Hayashi, S.; Omata, Y.; Sakamoto, H.; Higashimoto, Y.; Hara, T.; Sagara, Y.; Noguchi, M. Characterization of rat heme oxygenase-3 gene. Implication of processed pseudogenes derived from heme oxygenase-2 gene. Gene 2004, 336, 241-250. [CrossRef]

5. Nitti, M.; Piras, S.; Brondolo, L.; Marinari, U.M.; Pronzato, M.A.; Furfaro, A.L. Heme Oxygenase 1 in the Nervous System: Does It Favor Neuronal Cell Survival or Induce Neurodegeneration? Int. J. Mol. Sci. 2018, 19, 2260. [CrossRef]

6. Maines, M.D.; Trakshel, G.M.; Kutty, R.K. Characterization of two constitutive forms of rat liver microsomal heme oxygenase. Only one molecular species of the enzyme is inducible. J. Biol. Chem. 1986, 261, 411-419.

7. Prawan, A.; Kundu, J.K.; Surh, Y.J. Molecular basis of heme oxygenase-1 induction: Implications for chemoprevention and chemoprotection. Antioxid. Redox Signal. 2005, 7, 1688-1703. [CrossRef]

8. Li, M.; Kim, D.H.; Tsenovoy, P.L.; Peterson, S.J.; Rezzani, R.; Rodella, L.F.; Aronow, W.S.; Ikehara, S.; Abraham, N.G. Treatment of obese diabetic mice with a heme oxygenase inducer reduces visceral and subcutaneous adiposity, increases adiponectin levels, and improves insulin sensitivity and glucose tolerance. Diabetes 2008, 57, 1526-1535. [CrossRef]

9. Minamino, T.; Christou, H.; Hsieh, C.M.; Liu, Y.; Dhawan, V.; Abraham, N.G.; Perrella, M.A.; Mitsialis, S.A.; Kourembanas, S. Targeted expression of heme oxygenase-1 prevents the pulmonary inflammatory and vascular responses to hypoxia. Proc. Natl. Acad. Sci. USA 2001, 98, 8798-8803. [CrossRef]

10. Juan, S.H.; Lee, T.S.; Tseng, K.W.; Liou, J.Y.; Shyue, S.K.; Wu, K.K.; Chau, L.Y. Adenovirus-mediated heme oxygenase-1 gene transfer inhibits the development of atherosclerosis in apolipoprotein E-deficient mice. Circulation 2001, 104, 1519-1525. [CrossRef]

11. Hung, S.Y.; Liou, H.C.; Kang, K.H.; Wu, R.M.; Wen, C.C.; Fu, W.M. Overexpression of heme oxygenase-1 protects dopaminergic neurons against 1-methyl-4-phenylpyridinium-induced neurotoxicity. Mol. Pharmacol. 2008, 74, 1564-1575. [CrossRef] [PubMed] 
12. Sodhi, K.; Puri, N.; Favero, G.; Stevens, S.; Meadows, C.; Abraham, N.G.; Rezzani, R.; Ansinelli, H.; Lebovics, E.; Shapiro, J.I. Fructose Mediated Non-Alcoholic Fatty Liver Is Attenuated by HO-1-SIRT1 Module in Murine Hepatocytes and Mice Fed a High Fructose Diet. PLoS ONE 2015, 10, e0128648. [CrossRef] [PubMed]

13. Waza, A.A.; Hamid, Z.; Ali, S.; Bhat, S.A.; Bhat, M.A. A review on heme oxygenase-1 induction: Is it a necessary evil. Inflamm. Res. 2018, 67, 579-588. [CrossRef] [PubMed]

14. Sporn, M.B.; Suh, N. Chemoprevention: An essential approach to controlling cancer. Nat. Rev. Cancer 2002, 2, 537-543. [CrossRef]

15. Kang, N.J.; Shin, S.H.; Lee, H.J.; Lee, K.W. Polyphenols as small molecular inhibitors of signaling cascades in carcinogenesis. Pharmacol. Ther. 2011, 130, 310-324. [CrossRef]

16. Li Volti, G.; Sacerdoti, D.; Di Giacomo, C.; Barcellona, M.L.; Scacco, A.; Murabito, P.; Biondi, A.; Basile, F.; Gazzolo, D.; Abella, R.; et al. Natural heme oxygenase-1 inducers in hepatobiliary function. World J. Gastroenterol. 2008, 14, 6122-6132. [CrossRef]

17. Barbagallo, I.; Galvano, F.; Frigiola, A.; Cappello, F.; Riccioni, G.; Murabito, P.; D’Orazio, N.; Torella, M.; Gazzolo, D.; Li Volti, G. Potential therapeutic effects of natural heme oxygenase-1 inducers in cardiovascular diseases. Antioxid. Redox Signal. 2013, 18, 507-521. [CrossRef]

18. Ferrandiz, M.L.; Devesa, I. Inducers of heme oxygenase-1. Curr. Pharm. Des. 2008, 14, 473-486. [CrossRef]

19. Couillard, C.; Mauriege, P.; Imbeault, P.; Prud'homme, D.; Nadeau, A.; Tremblay, A.; Bouchard, C.; Despres, J.P. Hyperleptinemia is more closely associated with adipose cell hypertrophy than with adipose tissue hyperplasia. Int. J. Obes. Relat. Metab. Disord. 2000, 24, 782-788. [CrossRef]

20. Ogden, C.L.; Fryar, C.D.; Martin, C.B.; Freedman, D.S.; Carroll, M.D.; Gu, Q.; Hales, C.M. Trends in Obesity Prevalence by Race and Hispanic Origin-1999-2000 to 2017-2018. JAMA 2020. [CrossRef]

21. Hall, J.E. The kidney, hypertension, and obesity. Hypertension 2003, 41, 625-633. [CrossRef] [PubMed]

22. Al-Goblan, A.S.; Al-Alfi, M.A.; Khan, M.Z. Mechanism linking diabetes mellitus and obesity. Diabetes Metab. Syndr. Obes. 2014, 7, 587-591. [CrossRef] [PubMed]

23. Drummond, G.S.; Baum, J.; Greenberg, M.; Lewis, D.; Abraham, N.G. HO-1 overexpression and underexpression: Clinical implications. Arch. Biochem. Biophys. 2019, 673, 108073. [CrossRef] [PubMed]

24. Ndisang, J.F.; Jadhav, A.; Mishra, M. The heme oxygenase system suppresses perirenal visceral adiposity, abates renal inflammation and ameliorates diabetic nephropathy in Zucker diabetic fatty rats. PLoS ONE 2014, 9, e87936. [CrossRef] [PubMed]

25. Sowers, J.R.; Epstein, M.; Frohlich, E.D. Diabetes, hypertension, and cardiovascular disease: An update. Hypertension 2001, 37, 1053-1059. [CrossRef] [PubMed]

26. O'Donnell, C.J.; Kannel, W.B. Epidemiologic appraisal of hypertension as a coronary risk factor in the elderly. Am. J. Geriatr. Cardiol. 2002, 11, 86-92. [CrossRef] [PubMed]

27. Katholi, R.E.; Couri, D.M. Left ventricular hypertrophy: Major risk factor in patients with hypertension: Update and practical clinical applications. Int. J. Hypertens 2011, 2011, 495349. [CrossRef]

28. Shimzu, K.; Takahashi, T.; Iwasaki, T.; Shimizu, H.; Inoue, K.; Morimatsu, H.; Omori, E.; Matsumi, M.; Akagi, R.; Morita, K. Hemin treatment abrogates monocrotaline-induced pulmonary hypertension. Med. Chem. 2008, 4, 572-576. [CrossRef]

29. Burgess, A.; Li, M.; Vanella, L.; Kim, D.H.; Rezzani, R.; Rodella, L.; Sodhi, K.; Canestraro, M.; Martasek, P.; Peterson, S.J.; et al. Adipocyte heme oxygenase-1 induction attenuates metabolic syndrome in both male and female obese mice. Hypertension 2010, 56, 1124-1130. [CrossRef]

30. Filipovic, N.; Rosic, M.; Tanaskovic, I.; Milosevic, Z.; Nikolic, D.; Zdravkovic, N.; Peulic, A.; Kojic, M.R.; Fotiadis, D.I.; Parodi, O. ARTreat Project: Three-dimensional numerical simulation of plaque formation and development in the arteries. IEEE Trans. Inf. Technol. Biomed. 2012, 16, 272-278. [CrossRef]

31. Kishimoto, Y.; Kondo, K.; Momiyama, Y. The Protective Role of Heme Oxygenase-1 in Atherosclerotic Diseases. Int. J. Mol. Sci. 2019, 20, 3628. [CrossRef] [PubMed]

32. Radhakrishnan, N.; Yadav, S.P.; Sachdeva, A.; Pruthi, P.K.; Sawhney, S.; Piplani, T.; Wada, T.; Yachie, A. Human heme oxygenase-1 deficiency presenting with hemolysis, nephritis, and asplenia. J. Pediatr. Hematol. Oncol. 2011, 33, 74-78. [CrossRef] [PubMed]

33. Yachie, A.; Niida, Y.; Wada, T.; Igarashi, N.; Kaneda, H.; Toma, T.; Ohta, K.; Kasahara, Y.; Koizumi, S. Oxidative stress causes enhanced endothelial cell injury in human heme oxygenase-1 deficiency. J. Clin. Investig. 1999, 103, 129-135. [CrossRef] [PubMed] 
34. Ishikawa, K.; Sugawara, D.; Wang, X.; Suzuki, K.; Itabe, H.; Maruyama, Y.; Lusis, A.J. Heme oxygenase-1 inhibits atherosclerotic lesion formation in ldl-receptor knockout mice. Circ. Res. 2001, 88, 506-512. [CrossRef]

35. Ishikawa, K.; Sugawara, D.; Goto, J.; Watanabe, Y.; Kawamura, K.; Shiomi, M.; Itabe, H.; Maruyama, Y. Heme oxygenase-1 inhibits atherogenesis in Watanabe heritable hyperlipidemic rabbits. Circulation 2001, 104, 1831-1836. [CrossRef]

36. Poss, K.D.; Tonegawa, S. Reduced stress defense in heme oxygenase 1-deficient cells. Proc. Natl. Acad. Sci. USA 1997, 94, 10925-10930. [CrossRef]

37. Poss, K.D.; Tonegawa, S. Heme oxygenase 1 is required for mammalian iron reutilization. Proc. Natl. Acad. Sci. USA 1997, 94, 10919-10924. [CrossRef]

38. Ishikawa, K.; Navab, M.; Lusis, A.J. Vasculitis, Atherosclerosis, and Altered HDL Composition in Heme-Oxygenase-1-Knockout Mice. Int. J. Hypertens 2012, 2012, 948203. [CrossRef]

39. Teismann, P.; Tieu, K.; Choi, D.K.; Wu, D.C.; Naini, A.; Hunot, S.; Vila, M.; Jackson-Lewis, V.; Przedborski, S. Cyclooxygenase-2 is instrumental in Parkinson's disease neurodegeneration. Proc. Natl. Acad. Sci. USA 2003, 100, 5473-5478. [CrossRef]

40. Colombrita, C.; Calabrese, V.; Stella, A.M.; Mattei, F.; Alkon, D.L.; Scapagnini, G. Regional rat brain distribution of heme oxygenase-1 and manganese superoxide dismutase mRNA: Relevance of redox homeostasis in the aging processes. Exp. Biol. Med. 2003, 228, 517-524. [CrossRef]

41. More, S.; Choi, D.K. Neuroprotective Role of Atractylenolide-I in an In Vitro and In Vivo Model of Parkinson's Disease. Nutrients 2017, 9, 451. [CrossRef]

42. Masaki, Y.; Izumi, Y.; Matsumura, A.; Akaike, A.; Kume, T. Protective effect of Nrf2-ARE activator isolated from green perilla leaves on dopaminergic neuronal loss in a Parkinson's disease model. Eur. J. Pharmacol. 2017, 798, 26-34. [CrossRef] [PubMed]

43. Wang, K.; Tang, Y.; Yan, F.; Zhu, J.; Li, J. Potent inhibition of TGF-beta signaling pathway regulator Abl: Potential therapeutics for hepatic fibrosis. J. Recept. Signal. Transduct. Res. 2015, 35, 410-419. [CrossRef] [PubMed]

44. Lim, Y.S.; Kim, W.R. The global impact of hepatic fibrosis and end-stage liver disease. Clin. Liver Dis. 2008, 12, 733-746. [CrossRef] [PubMed]

45. Bauer, M.; Bauer, I. Heme oxygenase-1: Redox regulation and role in the hepatic response to oxidative stress. Antioxid. Redox Signal. 2002, 4, 749-758. [CrossRef] [PubMed]

46. Pratt, R.; Lakhani, H.V.; Zehra, M.; Desauguste, R.; Pillai, S.S.; Sodhi, K. Mechanistic Insight of Na/K-ATPase Signaling and HO-1 into Models of Obesity and Nonalcoholic Steatohepatitis. Int. J. Mol. Sci. 2019, $21,87$. [CrossRef]

47. Barikbin, R.; Neureiter, D.; Wirth, J.; Erhardt, A.; Schwinge, D.; Kluwe, J.; Schramm, C.; Tiegs, G.; Sass, G. Induction of heme oxygenase 1 prevents progression of liver fibrosis in Mdr2 knockout mice. Hepatology 2012, 55, 553-562. [CrossRef]

48. Mebratu, Y.; Tesfaigzi, Y. How ERK1/2 activation controls cell proliferation and cell death: Is subcellular localization the answer? Cell Cycle 2009, 8, 1168-1175. [CrossRef]

49. Li, Z.; Theus, M.H.; Wei, L. Role of ERK 1/2 signaling in neuronal differentiation of cultured embryonic stem cells. Dev. Growth Differ. 2006, 48, 513-523. [CrossRef]

50. Traore, K.; Sharma, R.; Thimmulappa, R.K.; Watson, W.H.; Biswal, S.; Trush, M.A. Redox-regulation of Erk1/2-directed phosphatase by reactive oxygen species: Role in signaling TPA-induced growth arrest in ML-1 cells. J. Cell Physiol. 2008, 216, 276-285. [CrossRef]

51. Chen, K.; Maines, M.D. Nitric oxide induces heme oxygenase-1 via mitogen-activated protein kinases ERK and p38. Cell Mol. Biol. 2000, 46, 609-617. [PubMed]

52. Wu, C.C.; Hsu, M.C.; Hsieh, C.W.; Lin, J.B.; Lai, P.H.; Wung, B.S. Upregulation of heme oxygenase-1 by Epigallocatechin-3-gallate via the phosphatidylinositol 3-kinase/Akt and ERK pathways. Life Sci. 2006, 78, 2889-2897. [CrossRef] [PubMed]

53. Yang, Y.C.; Lii, C.K.; Lin, A.H.; Yeh, Y.W.; Yao, H.T.; Li, C.C.; Liu, K.L.; Chen, H.W. Induction of glutathione synthesis and heme oxygenase 1 by the flavonoids butein and phloretin is mediated through the ERK/Nrf2 pathway and protects against oxidative stress. Free Radic. Biol. Med. 2011, 51, 2073-2081. [CrossRef] [PubMed] 
54. Ma, J.Q.; Ding, J.; Xiao, Z.H.; Liu, C.M. Puerarin ameliorates carbon tetrachloride-induced oxidative DNA damage and inflammation in mouse kidney through ERK/Nrf2/ARE pathway. Food Chem. Toxicol. 2014, 71, 264-271. [CrossRef]

55. Feng, J.; Zhang, P.; Chen, X.; He, G. PI3K and ERK/Nrf2 pathways are involved in oleanolic acid-induced heme oxygenase-1 expression in rat vascular smooth muscle cells. J. Cell Biochem. 2011, 112, 1524-1531. [CrossRef] [PubMed]

56. Yarza, R.; Vela, S.; Solas, M.; Ramirez, M.J. c-Jun N-terminal Kinase (JNK) Signaling as a Therapeutic Target for Alzheimer's Disease. Front. Pharmacol. 2015, 6, 321. [CrossRef]

57. Kietzmann, T.; Samoylenko, A.; Immenschuh, S. Transcriptional regulation of heme oxygenase-1 gene expression by MAP kinases of the JNK and p38 pathways in primary cultures of rat hepatocytes. J. Biol. Chem. 2003, 278, 17927-17936. [CrossRef]

58. Xiao, Q.; Piao, R.; Wang, H.; Li, C.; Song, L. Orientin-mediated Nrf2/HO-1 signal alleviates H2O2-induced oxidative damage via induction of JNK and PI3K/AKT activation. Int. J. Biol. Macromol. 2018, 118, 747-755. [CrossRef]

59. Zhang, H.; Liu, X.; Zhou, S.; Jia, Y.; Li, Y.; Song, Y.; Wang, J.; Wu, H. SP600125 suppresses Keap1 expression and results in NRF2-mediated prevention of diabetic nephropathy. J. Mol. Endocrinol. 2018, 60, 145-157. [CrossRef]

60. Tsai, K.H.; Wang, W.J.; Lin, C.W.; Pai, P.; Lai, T.Y.; Tsai, C.Y.; Kuo, W.W. NADPH oxidase-derived superoxide anion-induced apoptosis is mediated via the JNK-dependent activation of NF-kappaB in cardiomyocytes exposed to high glucose. J. Cell Physiol. 2012, 227, 1347-1357. [CrossRef]

61. Guan, J.; Wu, X.; Arons, E.; Christou, H. The p38 mitogen-activated protein kinase pathway is involved in the regulation of heme oxygenase- 1 by acidic extracellular $\mathrm{pH}$ in aortic smooth muscle cells. J. Cell Biochem. 2008, 105, 1298-1306. [CrossRef]

62. Carchman, E.H.; Rao, J.; Loughran, P.A.; Rosengart, M.R.; Zuckerbraun, B.S. Heme oxygenase-1-mediated autophagy protects against hepatocyte cell death and hepatic injury from infection/sepsis in mice. Hepatology 2011, 53, 2053-2062. [CrossRef] [PubMed]

63. Lee, S.E.; Jeong, S.I.; Yang, H.; Park, C.S.; Jin, Y.H.; Park, Y.S. Fisetin induces Nrf2-mediated HO-1 expression through PKC-delta and p38 in human umbilical vein endothelial cells. J. Cell Biochem. 2011, 112, 2352-2360. [CrossRef]

64. Zhou, M.M.; Zhang, W.Y.; Li, R.J.; Guo, C.; Wei, S.S.; Tian, X.M.; Luo, J.; Kong, L.Y. Anti-inflammatory activity of Khayandirobilide A from Khaya senegalensis via NF-kappaB, AP-1 and p38 MAPK/Nrf2/HO-1 signaling pathways in lipopolysaccharide-stimulated RAW 264.7 and BV-2 cells. Phytomedicine 2018, 42, 152-163. [CrossRef]

65. Downward, J. Mechanisms and consequences of activation of protein kinase B/Akt. Curr. Opin. Cell Biol. 1998, 10, 262-267. [CrossRef]

66. Songyang, Z.; Baltimore, D.; Cantley, L.C.; Kaplan, D.R.; Franke, T.F. Interleukin 3-dependent survival by the Akt protein kinase. Proc. Natl. Acad. Sci. USA 1997, 94, 11345-11350. [CrossRef]

67. Mo, L.; Yang, C.; Gu, M.; Zheng, D.; Lin, L.; Wang, X.; Lan, A.; Hu, F.; Feng, J. PI3K/Akt signaling pathway-induced heme oxygenase-1 upregulation mediates the adaptive cytoprotection of hydrogen peroxide preconditioning against oxidative injury in PC12 cells. Int. J. Mol. Med. 2012, 30, 314-320. [CrossRef]

68. Kwon, M.Y.; Park, E.; Lee, S.J.; Chung, S.W. Heme oxygenase-1 accelerates erastin-induced ferroptotic cell death. Oncotarget 2015, 6, 24393-24403. [CrossRef]

69. Hassannia, B.; Wiernicki, B.; Ingold, I.; Qu, F.; Van Herck, S.; Tyurina, Y.Y.; Bayir, H.; Abhari, B.A.; Angeli, J.P.F.; Choi, S.M.; et al. Nano-targeted induction of dual ferroptotic mechanisms eradicates high-risk neuroblastoma. J. Clin. Investig. 2018, 128, 3341-3355. [CrossRef]

70. Chang, L.C.; Chiang, S.K.; Chen, S.E.; Yu, Y.L.; Chou, R.H.; Chang, W.C. Heme oxygenase-1 mediates BAY 11-7085 induced ferroptosis. Cancer Lett. 2018, 416, 124-137. [CrossRef]

71. Vitek, L.; Schwertner, H.A. The heme catabolic pathway and its protective effects on oxidative stress-mediated diseases. Adv. Clin. Chem. 2007, 43, 1-57. [CrossRef] [PubMed]

72. Abraham, N.G.; Kappas, A. Pharmacological and clinical aspects of heme oxygenase. Pharmacol. Rev. 2008, 60, 79-127. [CrossRef] [PubMed] 
73. Johnson, J.A.; Johnson, D.A.; Kraft, A.D.; Calkins, M.J.; Jakel, R.J.; Vargas, M.R.; Chen, P.C. The Nrf2-ARE pathway: An indicator and modulator of oxidative stress in neurodegeneration. Ann. N. Y. Acad. Sci. 2008, 1147, 61-69. [CrossRef]

74. Canning, P.; Sorrell, F.J.; Bullock, A.N. Structural basis of Keap1 interactions with Nrf2. Free Radic. Biol. Med. 2015, 88, 101-107. [CrossRef] [PubMed]

75. Ishii, T.; Itoh, K.; Takahashi, S.; Sato, H.; Yanagawa, T.; Katoh, Y.; Bannai, S.; Yamamoto, M. Transcription factor Nrf2 coordinately regulates a group of oxidative stress-inducible genes in macrophages. J. Biol. Chem. 2000, 275, 16023-16029. [CrossRef] [PubMed]

76. Banerjee, P.; Basu, A.; Datta, D.; Gasser, M.; Waaga-Gasser, A.M.; Pal, S. The heme oxygenase-1 protein is overexpressed in human renal cancer cells following activation of the Ras-Raf-ERK pathway and mediates anti-apoptotic signal. J. Biol. Chem. 2011, 286, 33580-33590. [CrossRef] [PubMed]

77. Wijayanti, N.; Huber, S.; Samoylenko, A.; Kietzmann, T.; Immenschuh, S. Role of NF-kappaB and p38 MAP kinase signaling pathways in the lipopolysaccharide-dependent activation of heme oxygenase- 1 gene expression. Antioxid. Redox Signal. 2004, 6, 802-810. [CrossRef]

78. Guijarro-Munoz, I.; Compte, M.; Alvarez-Cienfuegos, A.; Alvarez-Vallina, L.; Sanz, L. Lipopolysaccharide activates Toll-like receptor 4 (TLR4)-mediated NF-kappaB signaling pathway and proinflammatory response in human pericytes. J. Biol. Chem. 2014, 289, 2457-2468. [CrossRef]

79. Karki, R.; Igwe, O.J. Toll-like receptor 4-mediated nuclear factor kappa B activation is essential for sensing exogenous oxidants to propagate and maintain oxidative/nitrosative cellular stress. PLoS ONE 2013, 8, e73840. [CrossRef]

80. Camhi, S.L.; Alam, J.; Otterbein, L.; Sylvester, S.L.; Choi, A.M. Induction of heme oxygenase-1 gene expression by lipopolysaccharide is mediated by AP-1 activation. Am. J. Respir. Cell Mol. Biol. 1995, 13, 387-398. [CrossRef]

81. Alam, J.; Cook, J.L. Transcriptional regulation of the heme oxygenase-1 gene via the stress response element pathway. Curr. Pharm. Des. 2003, 9, 2499-2511. [CrossRef]

82. Sun, J.; Hoshino, H.; Takaku, K.; Nakajima, O.; Muto, A.; Suzuki, H.; Tashiro, S.; Takahashi, S.; Shibahara, S.; Alam, J.; et al. Hemoprotein Bach1 regulates enhancer availability of heme oxygenase-1 gene. EMBO J. 2002, 21, 5216-5224. [CrossRef]

83. Zhang, X.; Guo, J.; Wei, X.; Niu, C.; Jia, M.; Li, Q.; Meng, D. Bach1: Function, Regulation, and Involvement in Disease. Oxid. Med. Cell Longev. 2018, 2018, 1347969. [CrossRef]

84. Mito, S.; Ozono, R.; Oshima, T.; Yano, Y.; Watari, Y.; Yamamoto, Y.; Brydun, A.; Igarashi, K.; Yoshizumi, M. Myocardial protection against pressure overload in mice lacking Bach1, a transcriptional repressor of heme oxygenase-1. Hypertension 2008, 51, 1570-1577. [CrossRef]

85. Hama, M.; Kirino, Y.; Takeno, M.; Takase, K.; Miyazaki, T.; Yoshimi, R.; Ueda, A.; Itoh-Nakadai, A.; Muto, A.; Igarashi, K.; et al. Bach1 regulates osteoclastogenesis in a mouse model via both heme oxygenase 1-dependent and heme oxygenase 1-independent pathways. Arthritis Rheum. 2012, 64, 1518-1528. [CrossRef] [PubMed]

86. Pu, M.; Li, C.; Qi, X.; Chen, J.; Wang, Y.; Gao, L.; Miao, L.; Ren, J. MiR-1254 suppresses HO-1 expression through seed region-dependent silencing and non-seed interaction with TFAP2A transcript to attenuate NSCLC growth. PLoS Genet. 2017, 13, e1006896. [CrossRef] [PubMed]

87. Beckman, J.D.; Chen, C.; Nguyen, J.; Thayanithy, V.; Subramanian, S.; Steer, C.J.; Vercellotti, G.M. Regulation of heme oxygenase-1 protein expression by miR-377 in combination with miR-217. J. Biol. Chem. 2011, 286, 3194-3202. [CrossRef] [PubMed]

88. Xiao, S.; Wang, X.; Ni, H.; Li, N.; Zhang, A.; Liu, H.; Pu, F.; Xu, L.; Gao, J.; Zhao, Q.; et al. MicroRNA $\mathrm{miR}-24-3 \mathrm{p}$ promotes porcine reproductive and respiratory syndrome virus replication through suppression of heme oxygenase-1 expression. J. Virol. 2015, 89, 4494-4503. [CrossRef] [PubMed]

89. Shan, Y.; Zheng, J.; Lambrecht, R.W.; Bonkovsky, H.L. Reciprocal effects of micro-RNA-122 on expression of heme oxygenase- 1 and hepatitis $C$ virus genes in human hepatocytes. Gastroenterology 2007, 133, 1166-1174. [CrossRef]

90. Piras, S.; Furfaro, A.L.; Caggiano, R.; Brondolo, L.; Garibaldi, S.; Ivaldo, C.; Marinari, U.M.; Pronzato, M.A.; Faraonio, R.; Nitti, M. microRNA-494 Favors HO-1 Expression in Neuroblastoma Cells Exposed to Oxidative Stress in a Bach1-Independent Way. Front. Oncol. 2018, 8, 199. [CrossRef]

91. Chiang, S.K.; Chen, S.E.; Chang, L.C. A Dual Role of Heme Oxygenase-1 in Cancer Cells. Int. J. Mol. Sci. 2018, 20, 39. [CrossRef] [PubMed] 
92. Durante, W. Targeting Heme Oxygenase-1 in the Arterial Response to Injury and Disease. Antioxidants 2020, 9, 829. [CrossRef] [PubMed]

93. Kähkönen, M.P.; Hopia, A.I.; Vuorela, H.J.; Rauha, J.-P.; Pihlaja, K.; Kujala, T.S.; Heinonen, M. Antioxidant Activity of Plant Extracts Containing Phenolic Compounds. J. Agric. Food Chem. 1999, 47, 3954-3962. [CrossRef]

94. Bendary, E.; Francis, R.R.; Ali, H.M.G.; Sarwat, M.I.; El Hady, S. Antioxidant and structure-activity relationships (SARs) of some phenolic and anilines compounds. Ann. Agric. Sci. 2013, 58, 173-181. [CrossRef]

95. Li, Y.; Yao, J.; Han, C.; Yang, J.; Chaudhry, M.T.; Wang, S.; Liu, H.; Yin, Y. Quercetin, inflammation and immunity. Nutrients 2016, 8, 167. [CrossRef]

96. Chen, J.-C.; Ho, F.-M.; Chao, P.-D.L.; Chen, C.-P.; Jeng, K.-C.G.; Hsu, H.-B.; Lee, S.-T.; Wu, W.T.; Lin, W.-W. Inhibition of iNOS gene expression by quercetin is mediated by the inhibition of IKB kinase, nuclear factor-kappa B and STAT1, and depends on heme oxygenase-1 induction in mouse BV-2 microglia. Eur. J. Pharm. 2005, 521, 9-20. [CrossRef]

97. Lin, H.-C.; Cheng, T.-H.; Chen, Y.-C.; Juan, S.-H. Mechanism of heme oxygenase-1 gene induction by quercetin in rat aortic smooth muscle cells. Pharmacology 2004, 71, 107-112. [CrossRef]

98. Chow, J.-M.; Shen, S.-C.; Huan, S.K.; Lin, H.-Y.; Chen, Y.-C. Quercetin, but not rutin and quercitrin, prevention of $\mathrm{H} 2 \mathrm{O} 2$-induced apoptosis via anti-oxidant activity and heme oxygenase 1 gene expression in macrophages. Biochem. Pharm. 2005, 69, 1839-1851. [CrossRef]

99. Liu, S.; Hou, W.; Yao, P.; Li, N.; Zhang, B.; Hao, L.; Nuessler, A.K.; Liu, L. Heme oxygenase-1 mediates the protective role of quercetin against ethanol-induced rat hepatocytes oxidative damage. Toxicol. In Vitro 2012, 26, 74-80. [CrossRef]

100. Yao, P.; Nussler, A.; Liu, L.; Hao, L.; Song, F.; Schirmeier, A.; Nussler, N. Quercetin protects human hepatocytes from ethanol-derived oxidative stress by inducing heme oxygenase-1 via the MAPK/Nrf2 pathways. J. Hepatol. 2007, 47, 253-261. [CrossRef]

101. Tang, Y.; Gao, C.; Shi, Y.; Zhu, L.; Hu, X.; Wang, D.; Lv, Y.; Yang, X.; Liu, L.; Yao, P. Quercetin attenuates ethanol-derived microsomal oxidative stress: Implication of haem oxygenase-1 induction. Food Chem. 2012, 132, 1769-1774. [CrossRef]

102. Kim, C.-S.; Choi, H.-S.; Joe, Y.; Chung, H.T.; Yu, R. Induction of heme oxygenase-1 with dietary quercetin reduces obesity-induced hepatic inflammation through macrophage phenotype switching. Nutr. Res. Pract. 2016, 10, 623-628. [CrossRef]

103. Yang, J.; Kim, C.-S.; Tu, T.H.; Kim, M.-S.; Goto, T.; Kawada, T.; Choi, M.-S.; Park, T.; Sung, M.-K.; Yun, J.W.; et al. Quercetin protects obesity-induced hypothalamic inflammation by reducing microglia-mediated inflammatory responses via HO-1 induction. Nutrients 2017, 9, 650. [CrossRef]

104. Kim, Y.; Kim, C.-S.; Joe, Y.; Chung, H.T.; Ha, T.Y.; Yu, R. Quercetin Reduces Tumor Necrosis Factor Alpha-Induced Muscle Atrophy by Upregulation of Heme Oxygenase-1. J. Med. Food 2018, 21, 551-559. [CrossRef]

105. Rayamajhi, N.; Kim, S.-K.; Go, H.; Joe, Y.; Callaway, Z.; Kang, J.-G.; Ryter, S.W.; Chung, H.T. Quercetin induces mitochondrial biogenesis through activation of HO-1 in HepG2 cells. Oxid. Med. Cell. Longev. 2013, 154211. [CrossRef]

106. Luo, M.; Tian, R.; Yang, Z.; Peng, Y.-Y.; Lu, N. Quercetin suppressed NADPH oxidase-derived oxidative stress via heme oxygenase-1 induction in macrophages. Arch. Biochem. Biophys. 2019, 671, 69-76. [CrossRef]

107. Tian, R.; Yang, Z.; Lu, N.; Peng, Y.-Y. Quercetin, but not rutin, attenuated hydrogen peroxide-induced cell damage via heme oxygenase-1 induction in endothelial cells. Arch. Biochem. Biophys. 2019. [CrossRef]

108. Hayashi, Y.; Matsushima, M.; Nakamura, T.; Shibasaki, M.; Hashimoto, N.; Imaizumi, K.; Shimokata, K.; Hasegawa, Y.; Kawabe, T. Quercetin protects against pulmonary oxidant stress via heme oxygenase-1 induction in lung epithelial cells. Biochem. Biophys. Res. Commun. 2012, 417, 169-174. [CrossRef]

109. Jin, J.Y.; Choi, E.Y.; Park, H.R.; Choi, J.I.; Choi, I.S.; Kim, S.J. Isorhamnetin inhibits Prevotella intermedia lipopolysaccharide-induced production of interleukin-6 in murine macrophages via anti-inflammatory heme oxygenase- 1 induction and inhibition of nuclear factor- $\mathrm{kB}$ and signal transducer and activator of transcription 1 activation. J. Periodontal Res. 2013, 48, 687-695. [CrossRef] 
110. Luo, Y.; Sun, G.; Dong, X.; Wang, M.; Qin, M.; Yu, Y.; Sun, X. Isorhamnetin attenuates atherosclerosis by inhibiting macrophage apoptosis via PI3K/AKT activation and HO-1 induction. PLoS ONE 2015, 10, e0120259. [CrossRef]

111. Choi, Y.H. The cytoprotective effect of isorhamnetin against oxidative stress is mediated by the upregulation of the Nrf2-dependent HO-1 expression in C2C12 myoblasts through scavenging reactive oxygen species and ERK inactivation. Gen. Physiol. Biophys. 2016, 35, 145-154. [CrossRef] [PubMed]

112. Dilshara, M.G.; Jayasooriya, R.G.P.T.; Lee, S.; Choi, Y.H.; Kim, G.-Y. Morin downregulates nitric oxide and prostaglandin E2 production in LPS-stimulated BV2 microglial cells by suppressing NF- $\mathrm{B}$ activity and activating HO-1 induction. Environ. Toxicol. Pharmacol. 2016, 44, 62-68. [CrossRef] [PubMed]

113. Tian, Y.; Li, Z.; Shen, B.; Zhang, Q.; Feng, H. Protective effects of morin on lipopolysaccharide/D-galactosamineinduced acute liver injury by inhibiting TLR4/NF- $\mathrm{BB}$ and activating Nrf2/HO-1 signaling pathways. Int. Immunopharmacol. 2017, 45, 148-155. [CrossRef]

114. Cho, B.O.; Yin, H.H.; Park, S.H.; Byun, E.B.; Ha, H.Y.; Jang, S.I. Anti-inflammatory activity of myricetin from Diospyros lotus through suppression of NF- $\mathrm{kB}$ and STAT1 activation and Nrf2-mediated HO-1 induction in lipopolysaccharide-stimulated RAW264.7 macrophages. Biosci. Biotechnol. Biochem. 2016, 80, 1520-1530. [CrossRef]

115. Paredes-Gonzalez, X.; Fuentes, F.; Jeffery, S.; Saw, C.L.-L.; Shu, L.; Su, Z.-Y.; Kong, A.-N.T. Induction of NRF2-mediated gene expression by dietary phytochemical flavones apigenin and luteolin. Biopharm. Drug Dispos. 2015, 36, 440-451. [CrossRef]

116. Park, E.J.; Kim, Y.M.; Kim, H.J.; Chang, K.C. Luteolin activates ERK1/2- and Ca2+-dependent HO-1 induction that reduces LPS-induced HMGB1, iNOS/NO, and COX-2 expression in RAW264.7 cells and mitigates acute lung injury of endotoxin mice. Inflam. Res. 2018, 67, 445-453. [CrossRef]

117. Liu, C.-W.; Lin, H.-W.; Yang, D.-J.; Chen, S.-Y.; Tseng, J.-K.; Chang, T.-J.; Chang, Y.-Y. Luteolin inhibits viral-induced inflammatory response in RAW264.7 cells via suppression of STAT1/3 dependent NF- $\mathrm{B}$ and activation of HO-1. Free Radical Biol. Med. 2016, 95, 180-189. [CrossRef]

118. Alekhya Sita, G.J.; Gowthami, M.; Srikanth, G.; Krishna, M.M.; Rama Sireesha, K.; Sajjarao, M.; Nagarjuna, K.; Nagarjuna, M.; Chinnaboina, G.K.; Mishra, A.; et al. Protective role of luteolin against bisphenol A-induced renal toxicity through suppressing oxidative stress, inflammation, and upregulating Nrf2/ARE/HO-1 pathway. IUBMB Life 2019, 71, 1041-1047. [CrossRef]

119. Hui, K.M.; Wang, X.H.; Xue, H. Interaction of flavones from the roots of Scutellaria baicalensis with the benzodiazepine site. Planta Med. 2000, 66, 91-93. [CrossRef] [PubMed]

120. Lee, Y.-M.; Cheng, P.-Y.; Chim, L.-S.; Kung, C.-W.; Ka, S.-M.; Chung, M.-T.; Sheu, J.-R. Baicalein, an active component of Scutellaria baicalensis Georgi, improves cardiac contractile function in endotoxaemic rats via induction of heme oxygenase-1 and suppression of inflammatory responses. J. Ethnopharmacol. 2011, 135, 179-185. [CrossRef]

121. Kwak, H.J.; Yang, D.; Hwang, Y.; Jun, H.-S.; Cheon, H.G. Baicalein protects rat insulinoma INS-1 cells from palmitate-induced lipotoxicity by inducing HO-1. PLoS ONE 2017, 12, e0176432. [CrossRef] [PubMed]

122. Huang, C.-S.; Lii, C.-K.; Lin, A.-H.; Yeh, Y.-W.; Yao, H.-T.; Li, C.-C.; Wang, T.-S.; Chen, H.-W. Protection by chrysin, apigenin, and luteolin against oxidative stress is mediated by the Nrf2-dependent up-regulation of heme oxygenase 1 and glutamate cysteine ligase in rat primary hepatocytes. Arch. Toxicol. 2013, 87, 167-178. [CrossRef]

123. Namkoong, S.; Sung, J.; Yang, J.; Choi, Y.; Jeong, H.S.; Lee, J. Nobiletin Attenuates the Inflammatory Response Through Heme Oxygenase-1 Induction in the Crosstalk Between Adipocytes and Macrophages. J. Med. Food 2017, 20, 873-881. [CrossRef] [PubMed]

124. Song, H.J.; Shin, C.Y.; Oh, T.Y.; Sohn, U.D. The protective effect of eupatilin on indomethacin-induced cell damage in cultured feline ileal smooth muscle cells: Involvement of HO-1 and ERK. J. Ethnopharm. 2008, 118, 94-101. [CrossRef] [PubMed]

125. Kang, C.-H.; Kim, M.J.; Seo, M.J.; Choi, Y.H.; Jo, W.S.; Lee, K.-T.; Jeong, Y.K.; Kim, G.-Y. 5-Hydroxy-3,6,7,8,3'4'-hexamethoxyflavone inhibits nitric oxide production in lipopolysaccharide-stimulated BV2 microglia via NF- $\mathrm{B}$ suppression and Nrf-2-dependent heme oxygenase-1 induction. Food Chem. Toxicol. 2013, 57, 119-125. [CrossRef] 
126. Li, B.; Lee, D.-S.; Jeong, G.-S.; Kim, Y.-C. Involvement of heme oxygenase-1 induction in the cytoprotective and immunomodulatory activities of 6,4'-dihydroxy-7-methoxyflavanone in murine hippocampal and microglia cells. Eur. J. Pharmacol. 2012, 674, 153-162. [CrossRef]

127. Kou, X.; Shen, K.; An, Y.; Qi, S.; Dai, W.-X.; Yin, Z. Ampelopsin Inhibits H2O2-induced Apoptosis by ERK and Akt Signaling Pathways and Up-regulation of Heme Oxygenase-1. Phytother. Res. 2012, 26, 988-994. [CrossRef]

128. Fan, R.; Pan, T.; Zhu, A.-L.; Zhang, M.-H. Anti-inflammatory and anti-arthritic properties of naringenin via attenuation of NF- $\mathrm{KB}$ and activation of the heme oxygenase (HO)-1/related factor 2 pathway. Pharmacol. Rep. 2017, 69, 1021-1029. [CrossRef]

129. Li, K.K.; Shen, S.S.; Deng, X.; Shiu, H.T.; Siu, W.S.; Leung, P.C.; Ko, C.H.; Cheng, B.H. Dihydrofisetin exerts its anti-inflammatory effects associated with suppressing ERK/p38 MAPK and Heme Oxygenase-1 activation in lipopolysaccharide-stimulated RAW 264.7 macrophages and carrageenan-induced mice paw edema. Int. Immunopharmacol. 2018, 54, 366-374. [CrossRef]

130. Kang, T.-H.; Jeong, S.-J.; Ko, W.-G.; Kim, N.-Y.; Lee, B.-H.; Inagaki, M.; Miyamoto, T.; Higuchi, R.; Kim, Y.-C. Cytotoxic lavandulyl flavanones from Sophora f lavescens. J. Nat. Prod. 2000, 63, 680-681. [CrossRef]

131. Jeong, G.-S.; Li, B.; Lee, D.-S.; Byun, E.; An, R.-B.; Pae, H.-O.; Chung, H.-T.; Youn, K.-H.; Kim, Y.-C. Lavandulyl flavanones from Sophora flavescens protect mouse hippocampal cells against glutamate-induced neurotoxicity via the induction of heme oxygenase-1. Biol. Pharm. Bull. 2008, 31, 1964-1967. [CrossRef] [PubMed]

132. Guo, C.; Yang, L.; Luo, J.; Zhang, C.; Xia, Y.; Ma, T.; Kong, L. Sophoraflavanone G from Sophora alopecuroides inhibits lipopolysaccharide-induced inflammation in RAW264.7 cells by targeting PI3K/Akt, JAK/STAT and Nrf2/HO-1 pathways. Int. Immunopharmacol. 2016, 38, 349-356. [CrossRef] [PubMed]

133. Higdon, J.V.; Frei, B. Tea catechins and polyphenols: Health effects, metabolism, and antioxidant functions. Crit. Rev. Food Sci. Nutr. 2003, 43, 89-143. [CrossRef]

134. Romeo, L.; Intrieri, M.; D'Agata, V.; Mangano, N.G.; Oriani, G.; Ontario, M.L.; Scapagnini, G. The major green tea polyphenol,(-)-epigallocatechin-3-gallate, induces heme oxygenase in rat neurons and acts as an effective neuroprotective agent against oxidative stress. J. Am. Coll. Nutr. 2009, 28, 492S-499S. [CrossRef] [PubMed]

135. Saito, K.; Mori, S.; Date, F.; Ono, M. Epigallocatechin gallate inhibits oxidative stress-induced DNA damage and apoptosis in MRL-Faslpr mice with autoimmune sialadenitis via upregulation of heme oxygenase-1 and Bcl-2. Autoimmunity 2014, 47, 13-22. [CrossRef] [PubMed]

136. Kim, Y.; Lee, J. Effect of (-)-epigallocatechin-3-gallate on anti-inflammatory response via heme oxygenase-1 induction during adipocyte-macrophage interactions. Food Sci. Biotech. 2016, 25, 1767-1773. [CrossRef]

137. Gao, Z.; Han, Y.; Hu, Y.; Wu, X.; Wang, Y.; Zhang, X.; Fu, J.; Zou, X.; Zhang, J.; Chen, X. Targeting HO-1 by epigallocatechin-3-gallate reduces contrast-induced renal injury via anti-oxidative stress and anti-inflammation pathways. PLoS ONE 2016, 11, e0149032. [CrossRef]

138. Pullikotil, P.; Chen, H.; Muniyappa, R.; Greenberg, C.C.; Yang, S.; Reiter, C.E.; Lee, J.-W.; Chung, J.H.; Quon, M.J. Epigallocatechin gallate induces expression of heme oxygenase-1 in endothelial cells via p38 MAPK and Nrf-2 that suppresses proinflammatory actions of TNF- $\alpha$. J. Nutr. Biochem. 2012, 23, 1134-1145. [CrossRef]

139. Di Carlo, G.; Mascolo, N.; Izzo, A.A.; Capasso, F. Flavonoids: Old and new aspects of a class of natural therapeutic drugs. Life Sci. 1999, 65, 337-353. [CrossRef]

140. Nowakowska, Z. A review of anti-infective and anti-inflammatory chalcones. Eur. J. Med. Chem. 2007, 42, 125-137. [CrossRef]

141. Lee, D.-S.; Li, B.; Kim, K.-S.; Jeong, G.-S.; Kim, E.-C.; Kim, Y.-C. Butein protects human dental pulp cells from hydrogen peroxide-induced oxidative toxicity via Nrf2 pathway-dependent heme oxygenase-1 expressions. Toxicol. In Vitro 2013, 27, 874-881. [CrossRef]

142. Wang, Z.; Ka, S.-O.; Lee, Y.; Park, B.-H.; Bae, E.J. Butein induction of HO-1 by p38 MAPK/Nrf2 pathway in adipocytes attenuates high-fat diet induced adipose hypertrophy in mice. Eur. J. Pharm. 2017, 799, 201-210. [CrossRef]

143. Shen, J.; Zhang, H.; Lin, H.; Su, H.; Xing, D.; Du, L. Brazilein protects the brain against focal cerebral ischemia reperfusion injury correlating to inflammatory response suppression. Eur. J. Pharm. 2007, 558, 88-95. [CrossRef] 
144. Yodsaoue, O.; Cheenpracha, S.; Karalai, C.; Ponglimanont, C.; Tewtrakul, S. Anti-allergic activity of principles from the roots and heartwood of caesalpinia sappan on antigen-induced $\beta$-hexosaminidase release. Phytother. Res. Int. J. Devoted Pharmacol. Toxicol. Eval. Nat. Prod. Deriv. 2009, 23, 1028-1031. [CrossRef]

145. Kim, J.-H.; Choo, Y.-Y.; Tae, N.; Min, B.-S.; Lee, J.-H. The anti-inflammatory effect of 3-deoxysappanchalcone is mediated by inducing heme oxygenase- 1 via activating the AKT/mTOR pathway in murine macrophages. Int. Immunopharmacol. 2014, 22, 420-426. [CrossRef] [PubMed]

146. Lee, Y.-M.; Jeong, G.-S.; Lim, H.-D.; An, R.-B.; Kim, Y.-C.; Kim, E.-C. Isoliquiritigenin 2' -methyl ether induces growth inhibition and apoptosis in oral cancer cells via heme oxygenase-1. Toxicol. In Vitro 2010, 24, 776-782. [CrossRef] [PubMed]

147. Lee, D.-S.; Li, B.; Im, N.-K.; Kim, Y.-C.; Jeong, G.-S. 4, 2' ' 5' -Trihydroxy-4'-methoxychalcone from Dalbergia odorifera exhibits anti-inflammatory properties by inducing heme oxygenase-1 in murine macrophages. Int. Immunopharmacol. 2013, 16, 114-121. [CrossRef]

148. Kil, J.-S.; Son, Y.; Cheong, Y.-K.; Kim, N.-H.; Jeong, H.J.; Kwon, J.-W.; Lee, E.-J.; Kwon, T.-O.; Chung, H.-T.; Pae, H.-O. Okanin, a chalcone found in the genus Bidens, and 3-penten-2-one inhibit inducible nitric oxide synthase expression via heme oxygenase-1 induction in RAW264. 7 macrophages activated with lipopolysaccharide. J. Clin. Biochem. Nutr. 2011. [CrossRef]

149. Li, Y.-Y.; Huang, S.-S.; Lee, M.-M.; Deng, J.-S.; Huang, G.-J. Anti-inflammatory activities of cardamonin from Alpinia katsumadai through heme oxygenase-1 induction and inhibition of NF- $\mathrm{kB}$ and MAPK signaling pathway in the carrageenan-induced paw edema. Int. Immunopharmacol. 2015, 25, 332-339. [CrossRef]

150. Nikolic, D.; B Van Breemen, R. Analytical methods for quantitation of prenylated flavonoids from hops. Curr. Anal. Chem. 2013, 9, 71-85. [CrossRef]

151. Lee, I.-S.; Lim, J.; Gal, J.; Kang, J.C.; Kim, H.J.; Kang, B.Y.; Choi, H.J. Anti-inflammatory activity of xanthohumol involves heme oxygenase-1 induction via NRF2-ARE signaling in microglial BV2 cells. Neurochem. Int. 2011, 58, 153-160. [CrossRef]

152. Choi, B.-M.; Oh, G.-S.; Lee, J.W.; Mok, J.Y.; Kim, D.K.; Jeong, S.-I.; Jang, S.I. Prenylated chalcone from Sophora flavescens suppresses Th2 chemokine expression induced by cytokines via heme oxygenase- 1 in human keratinocytes. Arch. Pharmacal Res. 2010, 33, 753-760. [CrossRef]

153. Su, X.; Huang, Q.; Chen, J.; Wang, M.; Pan, H.; Wang, R.; Zhou, H.; Zhou, Z.; Liu, J.; Yang, F. Calycosin suppresses expression of pro-inflammatory cytokines via the activation of p62/Nrf2-linked heme oxygenase 1 in rheumatoid arthritis synovial fibroblasts. Pharmacol. Res. 2016, 113, 695-704. [CrossRef]

154. Meng, X.-h.; Ni, C.; Zhu, L.; Shen, Y.-1.; Wang, L.-1.; Chen, Y. Puerarin protects against high glucose-induced acute vascular dysfunction: Role of heme oxygenase-1 in rat thoracic aorta. Vasc. Pharmacol. 2009, 50, 110-115. [CrossRef] [PubMed]

155. Hwang, Y.P.; Jeong, H.G. Mechanism of phytoestrogen puerarin-mediated cytoprotection following oxidative injury: Estrogen receptor-dependent up-regulation of PI3K/Akt and HO-1. Toxicol. Appl. Pharmacol. 2008, 233, 371-381. [CrossRef]

156. Lestari, M.L.; Indrayanto, G. Curcumin. In Profiles of Drug Substances, Excipients and Related Methodology; Elsevier: Amsterdam, The Netherlands, 2014; Volume 39, pp. 113-204.

157. Reddy, R.C.; Vatsala, P.G.; Keshamouni, V.G.; Padmanaban, G.; Rangarajan, P.N. Curcumin for malaria therapy. Biochem. Biophys. Res. Commun. 2005, 326, 472-474. [CrossRef]

158. Mahady, G.; Pendland, S.; Yun, G.; Lu, Z. Turmeric (Curcuma longa) and curcumin inhibit the growth of Helicobacter pylori, a group 1 carcinogen. Anticancer Res. 2002, 22, 4179-4181.

159. Terry, C.M.; Clikeman, J.A.; Hoidal, J.R.; Callahan, K.S. Effect of tumor necrosis factor- $\alpha$ and interleukin- $1 \alpha$ on heme oxygenase-1 expression in human endothelial cells. Am. J. Physiol. Heart Circ. Physiol. 1998, 274, H883-H891. [CrossRef]

160. Motterlini, R.; Foresti, R.; Bassi, R.; Green, C.J. Curcumin, an antioxidant and anti-inflammatory agent, induces heme oxygenase- 1 and protects endothelial cells against oxidative stress. Free Radic. Biol. Med. 2000, 28, 1303-1312. [CrossRef]

161. Hill-Kapturczak, N.; Thamilselvan, V.; Liu, F.; Nick, H.S.; Agarwal, A. Mechanism of heme oxygenase-1 gene induction by curcumin in human renal proximal tubule cells. Am. J. Physiol. Ren. Physiol. 2001. [CrossRef]

162. Balogun, E.; Hoque, M.; Gong, P.; Killeen, E.; Green, C.J.; Foresti, R.; Alam, J.; Motterlini, R. Curcumin activates the haem oxygenase-1 gene via regulation of $\mathrm{Nrf} 2$ and the antioxidant-responsive element. Biochem. J. 2003, 371, 887-895. [CrossRef] 
163. McNally, S.J.; Harrison, E.M.; Ross, J.A.; Garden, O.J.; Wigmore, S.J. Curcumin induces heme oxygenase 1 through generation of reactive oxygen species, p38 activation and phosphatase inhibition. Int. J. Mol. Med. 2007, 19, 165-172. [CrossRef]

164. Aggarwal, B.B.; Sundaram, C.; Malani, N.; Ichikawa, H. Curcumin: The Indian solid gold. In The Molecular Targets and Therapeutic Uses of Curcumin in Health and Disease; Springer: Berlin/Heidelberg, Germany, 2007; pp. 1-75.

165. Corson, T.W.; Crews, C.M. Molecular understanding and modern application of traditional medicines: Triumphs and trials. Cell 2007, 130, 769-774. [CrossRef]

166. Selvam, R.; Subramanian, L.; Gayathri, R.; Angayarkanni, N. The anti-oxidant activity of turmeric (Curcuma longa). J. Ethnopharmacol. 1995, 47, 59-67. [CrossRef]

167. Bao, W.; Li, K.; Rong, S.; Yao, P.; Hao, L.; Ying, C.; Zhang, X.; Nussler, A.; Liu, L. Curcumin alleviates ethanol-induced hepatocytes oxidative damage involving heme oxygenase-1 induction. J. Ethnopharmacol. 2010, 128, 549-553. [CrossRef]

168. Chen, M.-H.; Lee, M.-Y.; Chuang, J.-J.; Li, Y.-Z.; Ning, S.-T.; Chen, J.-C.; Liu, Y.-W. Curcumin inhibits HCV replication by induction of heme oxygenase-1 and suppression of AKT. Int. J. Mol. Med. 2012, 30, 1021-1028. [CrossRef]

169. Woo, J.M.; Shin, D.-Y.; Lee, S.J.; Joe, Y.; Zheng, M.; Yim, J.H.; Callaway, Z.; Chung, H.T. Curcumin protects retinal pigment epithelial cells against oxidative stress via induction of heme oxygenase- 1 expression and reduction of reactive oxygen. Mol. Vis. 2012, 18, 901.

170. Chen, D.; Wu, C.; Qiu, Y.-b.; Chu, Q.; Sun, X.-q.; Wang, X.; Chen, J.-1.; Lu, M.-d.; Chen, D.-z.; Pang, Q.-f. Curcumin ameliorates hepatic chronic inflammation induced by bile duct obstruction in mice through the activation of heme oxygenase-1. Int. Immunopharmacol. 2020, 78. [CrossRef]

171. Arslan, E.; Orzan, E.; Santarelli, R. Global Problem of Drug-Induced Hearing Loss. Ann. N. Y. Acad. Sci. 1999, 884, 1-14. [CrossRef]

172. Fetoni, A.R.; Eramo, S.L.; Paciello, F.; Rolesi, R.; Podda, M.V.; Troiani, D.; Paludetti, G. Curcuma longa (curcumin) decreases in vivo cisplatin-induced ototoxicity through heme oxygenase-1 induction. Otol. Neurotol. 2014, 35, e169-e177. [CrossRef]

173. Zheng, K.-m.; Zhang, J.; Zhang, C.-l.; Zhang, Y.-w.; Chen, X.-c. Curcumin inhibits appoptosin-induced apoptosis via upregulating heme oxygenase-1 expression in SH-SY5Y cells. Acta Pharm. Sin. 2015, 36, 544-552. [CrossRef] [PubMed]

174. Priyadarsini, K.I.; Maity, D.K.; Naik, G.; Kumar, M.S.; Unnikrishnan, M.; Satav, J.; Mohan, H. Role of phenolic $\mathrm{OH}$ and methylene hydrogen on the free radical reactions and antioxidant activity of curcumin. Free Radic. Biol. Med. 2003, 35, 475-484. [CrossRef]

175. Juan, S.-H.; Cheng, T.-H.; Lin, H.-C.; Chu, Y.-L.; Lee, W.-S. Mechanism of concentration-dependent induction of heme oxygenase-1 by resveratrol in human aortic smooth muscle cells. Biochem. Pharmacol. 2005, 69, 41-48. [CrossRef]

176. Lee, D.-S.; Cha, B.-Y.; Woo, J.-T.; Kim, Y.-C.; Jang, J.-H. Acerogenin a from Acer nikoense maxim prevents oxidative stress-induced neuronal cell death through Nrf2-mediated heme oxygenase-1 expression in mouse hippocampal HT22 cell line. Molecules 2015, 20, 12545-12557. [CrossRef] [PubMed]

177. Bankova, V. Chemical diversity of propolis makes it a valuable source of new biologically active compounds. J. Apiproduct Apimedical Sci. 2009, 1, 23-28. [CrossRef]

178. Murtaza, G.; Karim, S.; Akram, M.R.; Khan, S.A.; Azhar, S.; Mumtaz, A.; Bin Asad, M.H.H. Caffeic acid phenethyl ester and therapeutic potentials. Biomed Res. Int. 2014, 2014. [CrossRef] [PubMed]

179. Scapagnini, G.; Foresti, R.; Calabrese, V.; Stella, A.G.; Green, C.; Motterlini, R. Caffeic acid phenethyl ester and curcumin: A novel class of heme oxygenase-1 inducers. Mol. Pharmacol. 2002, 61, 554-561. [CrossRef]

180. Wang, X.; Stavchansky, S.; Zhao, B.; Bynum, J.A.; Kerwin, S.M.; Bowman, P.D. Cytoprotection of human endothelial cells from menadione cytotoxicity by caffeic acid phenethyl ester: The role of heme oxygenase-1. Eur. J. Pharmacol. 2008, 591, 28-35. [CrossRef]

181. Morroni, F.; Sita, G.; Graziosi, A.; Turrini, E.; Fimognari, C.; Tarozzi, A.; Hrelia, P. Neuroprotective effect of caffeic acid phenethyl ester in a mouse model of Alzheimer's disease involves Nrf2/HO-1 pathway. Aging Dis. 2018, 9, 605. [CrossRef] 
182. Kurauchi, Y.; Hisatsune, A.; Isohama, Y.; Mishima, S.; Katsuki, H. Caffeic acid phenethyl ester protects nigral dopaminergic neurons via dual mechanisms involving haem oxygenase-1 and brain-derived neurotrophic factor. Br. J. Pharmacol. 2012, 166, 1151-1168. [CrossRef]

183. Sorrenti, V.; Raffaele, M.; Vanella, L.; Acquaviva, R.; Salerno, L.; Pittalà, V.; Intagliata, S.; Di Giacomo, C. Protective effects of caffeic acid phenethyl ester (CAPE) and novel cape analogue as inducers of heme oxygenase-1 in streptozotocin-induced type 1 diabetic rats. Int. J. Mol. Sci. 2019, 20, 2441. [CrossRef] [PubMed]

184. Pittala, V.; Vanella, L.; Salerno, L.; Di Giacomo, C.; Acquaviva, R.; Raffaele, M.; Romeo, G.; N Modica, M.; Prezzavento, O.; Sorrenti, V. Novel caffeic acid phenethyl ester (Cape) analogues as inducers of heme oxygenase-1. Curr. Pharm. Des. 2017, 23, 2657-2664. [CrossRef] [PubMed]

185. Wang, X.; Stavchansky, S.; Kerwin, S.M.; Bowman, P.D. Structure-activity relationships in the cytoprotective effect of caffeic acid phenethyl ester (CAPE) and fluorinated derivatives: Effects on heme oxygenase-1 induction and antioxidant activities. Eur. J. Pharmacol. 2010, 635, 16-22. [CrossRef]

186. Kweon, M.-H.; Jung, M.-J.; Sung, H.-C. Cytoprotective effects of heme oxygenase-1 induction by 3-O-caffeoyl-1-methylquinic acid. Free Radic. Biol. Med. 2004, 36, 40-52. [CrossRef]

187. Jin, C.H.; Yang, H.S.; Choi, D.S.; Byun, M.W.; Kim, W.G.; Jeong, I.Y. Rosmarinic acid attenuated SIN-1-induced cytotoxicity in HepG2 cells through the HO-1 induction and radical scavenging activity. Food Sci. Biotechnol. 2013, 22, 549-556. [CrossRef]

188. So, Y.; Lee, S.Y.; Han, A.-R.; Kim, J.-B.; Jeong, H.G.; Jin, C.H. Rosmarinic acid methyl ester inhibits LPS-induced NO production via suppression of MyD88-dependent and-independent pathways and induction of HO-1 in RAW 264.7 cells. Molecules 2016, 21, 1083. [CrossRef]

189. Joe, Y.; Zheng, M.; Kim, H.J.; Kim, S.; Uddin, M.J.; Park, C.; Ryu, D.G.; Kang, S.S.; Ryoo, S.; Ryter, S.W.; et al. Salvianolic Acid B Exerts Vasoprotective Effects through the Modulation of Heme Oxygenase-1 and Arginase Activities. J. Pharmacol. Exp. Ther. 2012, 341, 850-858. [CrossRef]

190. Hwa, J.S.; Jin, Y.C.; Lee, Y.S.; Ko, Y.S.; Kim, Y.M.; Shi, L.Y.; Kim, H.J.; Lee, J.H.; Ngoc, T.M.; Bae, K.H.; et al. 2-Methoxycinnamaldehyde from Cinnamomum cassia reduces rat myocardial ischemia and reperfusion injury in vivo due to HO-1 induction. J. Ethnopharmacol. 2012, 139, 605-615. [CrossRef]

191. Martínez, L.; Ros, G.; Nieto, G. Hydroxytyrosol: Health Benefits and Use as Functional Ingredient in Meat. Medicines 2018, 5, 13. [CrossRef]

192. Zrelli, H.; Matsuoka, M.; Kitazaki, S.; Araki, M.; Kusunoki, M.; Zarrouk, M.; Miyazaki, H. Hydroxytyrosol Induces Proliferation and Cytoprotection against Oxidative Injury in Vascular Endothelial Cells: Role of Nrf2 Activation and HO-1 Induction. J. Agric. Food Chem. 2011, 59, 4473-4482. [CrossRef]

193. Zrelli, H.; Kusunoki, M.; Miyazaki, H. Role of Hydroxytyrosol-dependent Regulation of HO-1 Expression in Promoting Wound Healing of Vascular Endothelial Cells via Nrf2 De Novo Synthesis and Stabilization. Phytother. Res. 2015, 29, 1011-1018. [CrossRef]

194. Sgarbossa, A.; Dal Bosco, M.; Pressi, G.; Cuzzocrea, S.; Dal Toso, R.; Menegazzi, M. Phenylpropanoid glycosides from plant cell cultures induce heme oxygenase 1 gene expression in a human keratinocyte cell line by affecting the balance of NRF2 and BACH1 transcription factors. Chem. Biol. Interact. 2012, 199, 87-95. [CrossRef]

195. Das, A.B.; Goud, V.V.; Das, C. 9-Phenolic Compounds as Functional Ingredients in Beverages. In Value-Added Ingredients and Enrichments of Beverages; Grumezescu, A.M., Holban, A.M., Eds.; Academic Press: Cambridge, MA, USA, 2019; pp. 285-323. [CrossRef]

196. Hisamoto, M.; Kikuzaki, H.; Nakatani, N. Constituents of the leaves of Peucedanum japonicum Thunb. and their biological activity. J. Agric. Food Chem. 2004, 52, 445-450. [CrossRef]

197. Hisamoto, M.; Kikuzaki, H.; Ohigashi, H.; Nakatani, N. Antioxidant compounds from the leaves of Peucedanum japonicum Thunb. J. Agric. Food Chem. 2003, 51, 5255-5261. [CrossRef]

198. Taira, J.; Ogi, T. Induction of antioxidant protein HO-1 through Nrf2-ARE signaling due to pteryxin in Peucedanum japonicum Thunb in RAW264. 7 macrophage cells. Antioxidants 2019, 8, 621. [CrossRef]

199. Savouret, J.F.; Quesne, M. Resveratrol and cancer: A review. Biomed. Pharmacother. 2002, 56, 84-87. [CrossRef]

200. Orallo, F. Comparative studies of the antioxidant effects of cis-and trans-resveratrol. Curr. Med. Chem. 2006, 13, 87-98. [CrossRef]

201. Wadsworth, T.L.; Koop, D.R. Effects of the wine polyphenolics quercetin and resveratrol on pro-inflammatory cytokine expression in RAW 264.7 macrophages. Biochem. Pharmacol. 1999, 57, 941-949. [CrossRef] 
202. Frankel, D.; Mehindate, K.; Schipper, H.M. Role of heme oxygenase-1 in the regulation of manganese superoxide dismutase gene expression in oxidatively-challenged astroglia. J. Cell. Physiol. 2000, 185, 80-86. [CrossRef]

203. Kim, J.W.; Lim, S.C.; Lee, M.Y.; Lee, J.W.; Oh, W.K.; Kim, S.K.; Kang, K.W. Inhibition of neointimal formation by trans-resveratrol: Role of phosphatidyl inositol 3-kinase-dependent Nrf2 activation in heme oxygenase-1 induction. Mol. Nutr. Food Res. 2010, 54, 1497-1505. [CrossRef]

204. Zhuang, H.; KIM, Y.S.; Koehler, R.C.; Doré, S. Potential mechanism by which resveratrol, a red wine constituent, protects neurons. Ann. N. Y. Acad. Sci. 2003, 993, 276-286. [CrossRef] [PubMed]

205. Lin, T.-K.; Chen, S.-D.; Chuang, Y.-C.; Lin, H.-Y.; Huang, C.-R.; Chuang, J.-H.; Wang, P.-W.; Huang, S.-T.; Tiao, M.-M.; Chen, J.-B. Resveratrol partially prevents rotenone-induced neurotoxicity in dopaminergic SH-SY5Y cells through induction of heme oxygenase-1 dependent autophagy. Int. J. Mol. Sci. 2014, 15, 1625-1646. [CrossRef] [PubMed]

206. Gu, J.; Song, Z.-p.; Gui, D.-m.; Hu, W.; Chen, Y.-g.; Zhang, D.-d. Resveratrol attenuates doxorubicin-induced cardiomyocyte apoptosis in lymphoma nude mice by heme oxygenase-1 induction. Cardiovasc. Toxicol. 2012, 12, 341-349. [CrossRef]

207. Wung, B.-S.; Hsu, M.-C.; Wu, C.-C.; Hsieh, C.-W. Piceatannol upregulates endothelial heme oxygenase-1 expression via novel protein kinase $C$ and tyrosine kinase pathways. Pharmacol. Res. 2006, 53, 113-122. [CrossRef] [PubMed]

208. Lee, H.; Ko, W.; Chowdhury, A.; Li, B.; Kim, S.C.; Oh, H.; Kim, Y.C.; Woo, E.R.; Baek, N.I.; Lee, D.S. Brassicaphenanthrene A from Brassica rapa protects HT22 neuronal cells through the regulation of Nrf2-mediated heme oxygenase-1 expression. Mol. Med. Rep. 2020, 21, 493-500. [CrossRef]

209. Lee, W.; Yang, S.; Lee, C.; Park, E.K.; Kim, K.-M.; Ku, S.-K.; Bae, J.-S. Aloin reduces inflammatory gene iNOS via inhibition activity and p-STAT-1 and NF-кB. Food Chem. Toxicol. 2019, 126, 67-71. [CrossRef]

210. Shie, P.-H.; Wang, S.-Y.; Lay, H.-L.; Huang, G.-J. 4, 7-Dimethoxy-5-methyl-1, 3-benzodioxole from Antrodia camphorata inhibits LPS-induced inflammation via suppression of NF- $\mathrm{kB}$ and induction HO-1 in RAW264. 7 cells. Int. Immunopharmacol. 2016, 31, 186-194. [CrossRef] [PubMed]

211. Kim, D.-C.; Lee, D.-S.; Ko, W.; Kim, K.-W.; Kim, H.J.; Yoon, C.-S.; Oh, H.; Kim, Y.-C. Heme Oxygenase-1-Inducing Activity of 4-Methoxydalbergione and 4'-Hydroxy-4-methoxydalbergione from Dalbergia odorifera and Their Anti-inflammatory and Cytoprotective Effects in Murine Hippocampal and BV2 Microglial Cell Line and Primary Rat Microglial Cells. Neurotox. Res. 2018, 33, 337-352.

212. Ye, M.; Zhang, L.; Yan, Y.; Lin, H. Punicalagin protects H9c2 cardiomyocytes from doxorubicin-induced toxicity through activation of Nrf2/HO-1 signaling. Biosci. Rep. 2019, 39. [CrossRef]

213. Clementi, M.E.; Sampaolese, B.; Sciandra, F.; Tringali, G. Punicalagin Protects Human Retinal Pigment Epithelium Cells from Ultraviolet Radiation-Induced Oxidative Damage by Activating Nrf2/HO-1 Signaling Pathway and Reducing Apoptosis. Antioxidants 2020, 9, 473. [CrossRef]

214. Chen, H.; Li, H.; Cao, F.; Zhen, L.; Bai, J.; Yuan, S.; Mei, Y. 1,2,3,4,6-penta-O-galloyl- $\beta$-D-glucose protects PC12 Cells from MPP+-mediated cell death by inducing heme oxygenase-1 in an ERK- and Akt-dependent manner. J. Huazhong Univ. Sci. Technol. Med. Sci. 2012, 32, 737-745. [CrossRef]

215. Gschwendt, M.; Muller, H.; Kielbassa, K.; Zang, R.; Kittstein, W.; Rincke, G.; Marks, F. Rottlerin, a novel protein kinase inhibitor. Biochem. Biophys. Res. Commun. 1994, 199, 93-98. [CrossRef]

216. Park, E.J.; Lim, J.H.; Nam, S.I.; Park, J.W.; Kwon, T.K. Rottlerin induces heme oxygenase-1 (HO-1) up-regulation through reactive oxygen species (ROS) dependent and PKC $\delta$-independent pathway in human colon cancer HT29 cells. Biochimie 2010, 92, 110-115. [CrossRef]

217. Chen, L.; Teng, H.; Zhang, K.Y.; Skalicka-Wozniak, K.; Georgiev, M.I.; Xiao, J. Agrimonolide and desmethylagrimonolide induced HO-1 expression in HepG2 cells through Nrf2-transduction and p38 inactivation. Front. Pharmacol. 2016, 7, 513. [CrossRef]

218. Chen, W.-C.; Wang, S.-Y.; Chiu, C.-C.; Tseng, C.-K.; Lin, C.-K.; Wang, H.-C.; Lee, J.-C. Lucidone suppresses hepatitis $\mathrm{C}$ virus replication by Nrf2-mediated heme oxygenase-1 induction. Antimicrob. Agents Chemother. 2013, 57, 1180-1191. [CrossRef]

219. Kim, K.C.; Kang, K.A.; Zhang, R.; Piao, M.J.; Kim, G.Y.; Kang, M.Y.; Lee, S.J.; Lee, N.H.; Surh, Y.-J.; Hyun, J.W. Up-regulation of Nrf2-mediated heme oxygenase-1 expression by eckol, a phlorotannin compound, through activation of Erk and PI3K/Akt. Int. J. Biochem. Cell Biol. 2010, 42, 297-305. [CrossRef] 
220. Lee, S.; Seo, J.; Ryoo, S.; Cuong, T.D.; Min, B.-S.; Lee, J.-H. Malabaricone C inhibits PDGF-induced proliferation and migration of aortic smooth muscle cells through induction of heme oxygenase-1. J. Cell. Biochem. 2012, 113, 2866-2876. [CrossRef]

221. Jiang, G.; Hu, Y.; Liu, L.; Cai, J.; Peng, C.; Li, Q. Gastrodin protects against MPP+-induced oxidative stress by up regulates heme oxygenase-1 expression through p38 MAPK/Nrf2 pathway in human dopaminergic cells. Neurochem. Int. 2014, 75, 79-88. [CrossRef] [PubMed]

222. Zhang, H.; Yuan, B.; Huang, H.; Qu, S.; Yang, S.; Zeng, Z. Gastrodin induced HO-1 and Nrf2 up-regulation to alleviate $\mathrm{H} 2 \mathrm{O} 2$-induced oxidative stress in mouse liver sinusoidal endothelial cells through p38 MAPK phosphorylation. Braz. J. Med. Biol. Res. 2018, 51, e7439. [CrossRef] [PubMed]

223. Farkhondeh, T.; Samarghandian, S.; Borji, A. An overview on cardioprotective and anti-diabetic effects of thymoquinone. Asian Pac. J. Trop. Med. 2017, 10, 849-854. [CrossRef]

224. Kundu, J.; Kim, D.-H.; Kundu, J.K.; Chun, K.-S. Thymoquinone induces heme oxygenase-1 expression in HaCaT cells via Nrf2/ARE activation: Akt and AMPK $\alpha$ as upstream targets. Food Chem. Toxicol. 2014, 65, 18-26. [CrossRef] [PubMed]

225. Moon, M.K.; Choi, B.-M.; Oh, G.-S.; Pae, H.-O.; Kim, J.-D.; Oh, H.; Oh, C.-S.; Kim, D.-H.; Rho, Y.-D.; Shin, M.-K.; et al. Catalposide protects Neuro 2A cells from hydrogen peroxide-induced cytotoxicity via the expression of heme oxygenase-1. Toxicol. Lett. 2003, 145, 46-54. [CrossRef]

226. Bae, G.-S.; Kim, D.-G.; Jo, I.-J.; Choi, S.-B.; Kim, M.-J.; Shin, J.Y.; Kim, D.-U.; Song, H.-J.; Joo, M.; Park, S.-J. Heme oxygenase-1 induced by desoxo-narchinol-A attenuated the severity of acute pancreatitis via blockade of neutrophil infiltration. Int. Immunopharmacol. 2019, 69, 225-234. [CrossRef] [PubMed]

227. Kim, K.-W.; Yoon, C.-S.; Kim, Y.-C.; Oh, H. Desoxo-narchinol A and Narchinol B Isolated from Nardostachys jatamansi Exert Anti-neuroinflammatory Effects by Up-regulating of Nuclear Transcription Factor Erythroid-2-Related Factor 2/Heme Oxygenase-1 Signaling. Neurotoxic. Res. 2019, 35, 230-243. [CrossRef]

228. Duñg, N.X.; Chińh, T.D.; Rañg, D.D.; Leclercq, P.A. The constituents of the rhizome oil of Zingiber zerumbet (L.) Sm. from Vietnam. J. Essent. Oil Res. 1993, 5, 553-555. [CrossRef]

229. Leung, W.-S.; Yang, M.-L.; Lee, S.-S.; Kuo, C.-W.; Ho, Y.-C.; Huang-Liu, R.; Lin, H.-W.; Kuan, Y.-H. Protective effect of zerumbone reduces lipopolysaccharide-induced acute lung injury via antioxidative enzymes and Nrf2/HO-1 pathway. Int. Immunopharmacol. 2017, 46, 194-200. [CrossRef]

230. Shin, J.-W.; Ohnishi, K.; Murakami, A.; Lee, J.-S.; Kundu, J.K.; Na, H.-K.; Ohigashi, H.; Surh, Y.-J. Zerumbone induces heme oxygenase-1 expression in mouse skin and cultured murine epidermal cells through activation of Nrf2. Cancer Prev. Res. 2011, 4, 860-870. [CrossRef]

231. Tsoyi, K.; Jang, H.J.; Lee, Y.S.; Kim, Y.M.; Kim, H.J.; Seo, H.G.; Lee, J.H.; Kwak, J.H.; Lee, D.-U.; Chang, K.C. $(+)$-Nootkatone and (+)-valencene from rhizomes of Cyperus rotundus increase survival rates in septic mice due to heme oxygenase-1 induction. J. Ethnopharmacol. 2011, 137, 1311-1317. [CrossRef]

232. Lee, D.-S.; Choi, H.-G.; Wan Woo, K.; Kang, D.-G.; Lee, H.-S.; Oh, H.; Ro Lee, K.; Kim, Y.-C. Pulchellamin $\mathrm{G}$, an amino acid-sesquiterpene lactone, from Saussurea pulchella suppresses lipopolysaccharide-induced inflammatory responses via heme oxygenase-1 expression in murine peritoneal macrophages. Eur. J. Pharmacol. 2013, 715, 123-132. [CrossRef]

233. Jeong, G.-S.; Pae, H.-O.; Jeong, S.-O.; Kim, Y.-C.; Kwon, T.-O.; Lee, H.S.; Kim, N.-S.; Park, S.D.; Chung, H.-T. The $\alpha$-methylene- $\gamma$-butyrolactone moiety in dehydrocostus lactone is responsible for cytoprotective heme oxygenase-1 expression through activation of the nuclear factor E2-related factor 2 in HepG2 cells. Eur. J. Pharmacol. 2007, 565, 37-44. [CrossRef]

234. Park, E.J.; Park, S.W.; Kim, H.J.; Kwak, J.-H.; Lee, D.-U.; Chang, K.C. Dehydrocostuslactone inhibits LPS-induced inflammation by p38MAPK-dependent induction of hemeoxygenase-1 in vitro and improves survival of mice in CLP-induced sepsis in vivo. Int. Immunopharmacol. 2014, 22, 332-340. [CrossRef] [PubMed]

235. Kim, N.; Hwangbo, C.; Lee, S.; Lee, J.-H. Eupatolide Inhibits PDGF-induced Proliferation and Migration of Aortic Smooth Muscle Cells Through ROS-dependent Heme Oxygenase-1 Induction. Phytother. Res. 2013, 27, 1700-1707. [CrossRef] [PubMed]

236. Shen, X.-Y.; Qin, D.-P.; Zhou, H.; Luo, J.-F.; Yao, Y.-D.; Lio, C.-K.; Li, H.-B.; Dai, Y.; Yu, Y.; Yao, X.-S. Nardochinoids $\mathrm{a}-\mathrm{C}$, three dimeric sesquiterpenoids with specific fused-ring skeletons from nardostachys chinensis. Org. Lett. 2018, 20, 5813-5816. [CrossRef] [PubMed] 
237. Yao, Y.-D.; Shen, X.-Y.; Machado, J.; Luo, J.-F.; Dai, Y.; Lio, C.-K.; Yu, Y.; Xie, Y.; Luo, P.; Liu, J.-X.; et al. Nardochinoid B inhibited the activation of RAW264.7 macrophages stimulated by lipopolysaccharide through activating the Nrf2/HO-1 pathway. Molecules 2019, 24, 2482. [CrossRef] [PubMed]

238. Muroi, H.; Kubo, I. Antibacterial activity of anacardic acid and totarol, alone and in combination with methicillin, against methicillinresistant Staphylococcus aureus. J. Appl. Bacteriol. 1996, 80, 387-394. [CrossRef] [PubMed]

239. Gao, Y.; Xu, X.; Chang, S.; Wang, Y.; Xu, Y.; Ran, S.; Huang, Z.; Li, P.; Li, J.; Zhang, L.; et al. Totarol prevents neuronal injury in vitro and ameliorates brain ischemic stroke: Potential roles of Akt activation and HO-1 induction. Toxicol. Appl. Pharmacol. 2015, 289, 142-154. [CrossRef]

240. Martin, D.; Rojo, A.I.; Salinas, M.; Diaz, R.; Gallardo, G.; Alam, J.; Ruiz de Galarreta, C.M.; Cuadrado, A. Regulation of Heme Oxygenase-1 Expression through the Phosphatidylinositol 3-Kinase/Akt Pathway and the Nrf2 Transcription Factor in Response to the Antioxidant Phytochemical Carnosol. J. Biol. Chem. 2004, 279, 8919-8929. [CrossRef]

241. Campbell, N.K.; Fitzgerald, H.K.; Fletcher, J.M.; Dunne, A. Plant-derived polyphenols modulate human dendritic cell metabolism and immune function via AMPK-dependent induction of heme oxygenase-1. Front. Immunol. 2019, 10, 345. [CrossRef]

242. Ha, D.T.; Phuong, T.T.; Oh, J.; Bae, K.H.; Nguyen, D.T.; Na, M. Palbinone from Paeonia suffruticosa Protects Hepatic Cells via Up-regulation of Heme Oxygenase-1. Phytother. Res. 2014, 28, 308-311. [CrossRef]

243. Zhang, Y.; Liu, J.; Jia, W.; Zhao, A.; Li, T. Distinct immunosuppressive effect by Isodon serra extracts. Int. Immunopharmacol. 2005, 5, 1957-1965. [CrossRef]

244. Hu, A.P.; Du, J.M.; Li, J.Y.; Liu, J.W. Oridonin promotes CD4+/CD25+ Treg differentiation, modulates Th1/Th2 balance and induces HO-1 in rat splenic lymphocytes. Inflamm. Res. 2008, 57, 163-170. [CrossRef] [PubMed]

245. Mishra, S.K.; Sangwan, N.S.; Sangwan, R.S. Phcog Rev.: Plant Review Andrographis paniculata (Kalmegh): A Review. Pharmacogn. Rev. 2007, 1, 283-298.

246. Yu, A.-L.; Lu, C.-Y.; Wang, T.-S.; Tsai, C.-W.; Liu, K.-L.; Cheng, Y.-P.; Chang, H.C.; Lii, C.-K.; Chen, H.-W. Induction of Heme Oxygenase 1 and Inhibition of Tumor Necrosis Factor $\alpha$-Induced Intercellular Adhesion Molecule Expression by Andrographolide in EA.hy926 Cells. J. Agric. Food Chem. 2010, 58, 7641-7648. [CrossRef] [PubMed]

247. Uto, T.; Qin, G.-W.; Morinaga, O.; Shoyama, Y. 17-Hydroxy-jolkinolide B, a diterpenoid from Euphorbia fischeriana, inhibits inflammatory mediators but activates heme oxygenase-1 expression in lipopolysaccharide-stimulated murine macrophages. Int. Immunopharmacol. 2012, 12, 101-109. [CrossRef]

248. Yan, S.C.; Wang, Y.J.; Li, Y.J.; Cai, W.Y.; Weng, X.G.; Li, Q.; Chen, Y.; Yang, Q.; Zhu, X.X. Dihydroartemisinin regulates the $\mathrm{Th} /$ Treg balance by inducing activated $\mathrm{CD} 4+\mathrm{T}$ cell apoptosis via heme oxygenase-1 induction in mouse models of inflammatory bowel disease. Molecules 2019, 24, 2475. [CrossRef]

249. Wang, Y.; Li, L.; Wang, Y.; Zhu, X.; Jiang, M.; Song, E.; Song, Y. New application of the commercial sweetener rebaudioside a as a hepatoprotective candidate: Induction of the Nrf2 signaling pathway. Eur. J. Pharmacol. 2018, 822, 128-137. [CrossRef]

250. Setty, A.R.; Sigal, L.H. Herbal medications commonly used in the practice of rheumatology: Mechanisms of action, efficacy, and side effects. Semin. Arthritis Rheum. 2005, 34, 773-784. [CrossRef]

251. Yu, X.; Tao, W.; Jiang, F.; Li, C.; Lin, J.; Liu, C. Celastrol Attenuates Hypertension-Induced Inflammation and Oxidative Stress in Vascular Smooth Muscle Cells via Induction of Heme Oxygenase-1. Am. J. Hypertens. 2010, 23, 895-903. [CrossRef]

252. Youn, G.S.; Kwon, D.-J.; Ju, S.M.; Rhim, H.; Bae, Y.S.; Choi, S.Y.; Park, J. Celastrol ameliorates HIV-1 Tat-induced inflammatory responses via NF-kappaB and AP-1 inhibition and heme oxygenase-1 induction in astrocytes. Toxicol. Appl. Pharmacol. 2014, 280, 42-52. [CrossRef]

253. Tseng, C.-K.; Hsu, S.-P.; Lin, C.-K.; Wu, Y.-H.; Lee, J.-C.; Young, K.-C. Celastrol inhibits hepatitis C virus replication by upregulating heme oxygenase-1 via the JNK MAPK/Nrf2 pathway in human hepatoma cells. Antiviral Res. 2017, 146, 191-200. [CrossRef]

254. Luo, D.; Guo, Y.; Cheng, Y.; Zhao, J.; Wang, Y.; Rong, J. Natural product celastrol suppressed macrophage M1 polarization against inflammation in diet-induced obese mice via regulating Nrf2/HO-1, MAP kinase and NF-kB pathways. Aging 2017, 9, 2069-2082. [CrossRef] [PubMed]

255. Jeong, G.-S.; An, R.-B.; Pae, H.-O.; Oh, G.-S.; Chung, H.-T.; Kim, Y.-C. Heme oxygenase-1 inducing constituent of Prunella vulgaris in HepG2 cells. Biol. Pharm. Bull. 2008, 31, 531-533. [CrossRef] [PubMed] 
256. Barker, E.C.; Gatbonton-Schwager, T.N.; Han, Y.; Clay, J.E.; Letterio, J.J.; Tochtrop, G.P. Bryonolic Acid: A Large-Scale Isolation and Evaluation of Heme Oxygenase 1 Expression in Activated Macrophages. J. Nat. Prod. 2010, 73, 1064-1068. [CrossRef] [PubMed]

257. Tung, N.T.; Cuong, T.D.; Hung, T.M.; Lee, J.H.; Woo, M.H.; Choi, J.S.; Kim, J.; Ryu, S.H.; Min, B.S. Inhibitory effect on NO production of triterpenes from the fruiting bodies of Ganoderma lucidum. Bioorg. Med. Chem. Lett. 2013, 23, 1428-1432. [CrossRef]

258. Choi, S.; Nguyen, V.T.; Tae, N.; Lee, S.; Ryoo, S.; Min, B.-S.; Lee, J.-H. Anti-inflammatory and heme oxygenase-1 inducing activities of lanostane triterpenes isolated from mushroom Ganoderma lucidum in RAW264.7 cells. Toxicol. Appl. Pharmacol. 2014, 280, 434-442. [CrossRef]

259. Kim, Y.M.; Kim, H.J.; Chang, K.C. Glycyrrhizin reduces HMGB1 secretion in lipopolysaccharide-activated RAW 264.7 cells and endotoxemic mice by p38/Nrf2-dependent induction of HO-1. Int. Immunopharmacol. 2015, 26, 112-118. [CrossRef]

260. Mou, K.; Pan, W.; Han, D.; Wen, X.; Cao, F.; Miao, Y.; Li, P. Glycyrrhizin protects human melanocytes from $\mathrm{H} 2 \mathrm{O} 2-i n d u c e d$ oxidative damage via the Nrf2-dependent induction of HO-1. Int. J. Mol. Med. 2019, 44, 253-261. [CrossRef]

261. Bian, X.; Liu, X.; Liu, J.; Zhao, Y.; Li, H.; Zhang, L.; Li, P.; Gao, Y. Hepatoprotective effect of chiisanoside from Acanthopanax sessiliflorus against LPS/D-GalN-induced acute liver injury by inhibiting NF-kB and activating Nrf2/HO-1 signaling pathways. J. Sci. Food Agric. 2019, 99, 3283-3290. [CrossRef] [PubMed]

262. Heyninck, K.; Sabbe, L.; Chirumamilla, C.S.; Szarc vel Szic, K.; Vander Veken, P.; Lemmens, K.J.A.; Lahtela-Kakkonen, M.; Naulaerts, S.; Op de Beeck, K.; Laukens, K.; et al. Withaferin A induces heme oxygenase (HO-1) expression in endothelial cells via activation of the Keap1/Nrf2 pathway. Biochem. Pharmacol. 2016, 109, 48-61. [CrossRef] [PubMed]

263. Shi, W.; Wang, Y.; Li, J.; Zhang, H.; Ding, L. Investigation of ginsenosides in different parts and ages of Panax ginseng. Food Chem. 2007, 102, 664-668. [CrossRef]

264. Chang-Xiao, L.; Pei-Gen, X. Recent advances on ginseng research in China. J. Ethnopharmacol. 1992, 36, 27-38. [CrossRef]

265. Chen, R.J.; Chung, T.-y.; Li, F.-y.; Lin, N.-h.; TzEN, J.T. Effect of sugar positions in ginsenosides and their inhibitory potency on Na+/K+-ATPase activity. Acta Pharmacol. Sin. 2009, 30, 61-69. [CrossRef] [PubMed]

266. Hwang, Y.P.; Jeong, H.G. Ginsenoside Rb1 protects against 6-hydroxydopamine-induced oxidative stress by increasing heme oxygenase-1 expression through an estrogen receptor-related PI3K/Akt/Nrf2-dependent pathway in human dopaminergic cells. Toxicol. Appl. Pharmacol. 2010, 242, 18-28. [CrossRef] [PubMed]

267. Kim, M.; Choi, S.Y.; Kim, K.-T.; Rhee, Y.K.; Hur, J. Ginsenoside Rg18 suppresses lipopolysaccharide-induced neuroinflammation in BV2 microglia and amyloid- $\beta$-induced oxidative stress in SH-SY5Y neurons via nuclear factor erythroid 2-related factor 2/heme oxygenase-1 induction. J. Funct. Foods 2017, 31, 71-78. [CrossRef]

268. Yan, T.; Yu, X.; Sun, X.; Meng, D.; Jia, J.-m. A new steroidal saponin, furotrilliumoside from Trillium tschonoskii inhibits lipopolysaccharide-induced inflammation in Raw264.7 cells by targeting PI3K/Akt, MARK and Nrf2/HO-1 pathways. Fitoterapia 2016, 115, 37-45. [CrossRef] [PubMed]

269. Higuera-Ciapara, I.; Felix-Valenzuela, L.; Goycoolea, F. Astaxanthin: A review of its chemistry and applications. Crit. Rev. Food Sci. Nutr. 2006, 46, 185-196. [CrossRef]

270. Ma, H.; Chen, S.; Xiong, H.; Wang, M.; Hang, W.; Zhu, X.; Zheng, Y.; Ge, B.; Li, R.; Cui, H. Astaxanthin from Haematococcus pluvialis ameliorates the chemotherapeutic drug (doxorubicin) induced liver injury through the Keap1/Nrf2/HO-1 pathway in mice. Food Funct. 2020, 11, 4659-4671. [CrossRef]

271. Yan, N.; Liu, Y.; Gong, D.; Du, Y.; Zhang, H.; Zhang, Z. Solanesol: A review of its resources, derivatives, bioactivities, medicinal applications, and biosynthesis. Phytochem. Rev. 2015, 14, 403-417. [CrossRef]

272. Yao, X.; Lu, B.; Lu, C.; Bai, Q.; Yan, D.; Wu, Y.; Hong, Z.; Xu, H. Solanesol induces the expression of heme oxygenase-1 via p38 and Akt and suppresses the production of proinflammatory cytokines in RAW264.7 cells. Food Funct. 2017, 8, 132-141. [CrossRef]

273. Lee, S.E.; Kim, G.-D.; Yang, H.; Son, G.W.; Park, H.R.; Cho, J.-J.; Ahn, H.-J.; Park, C.-S.; Park, Y.S. Effects of Eicosapentaenoic Acid on the Cytoprotection Through Nrf2-Mediated Heme Oxygenase-1 in Human Endothelial Cells. J. Cardiovasc. Pharmacol. 2015, 66, 108-117. [CrossRef] 
274. Cui, Z.-G.; Ogawa, R.; Tsuneyama, K.; Yan, G.; Tao, L.; Shimomura, A.; Inadera, H. Insight into the molecular mechanism of heme oxygenase-1 induction by docosahexaenoic acid in U937 cells. Chem. Biol. Interact. 2015, 238, 180-188. [CrossRef] [PubMed]

275. Hou, C.-C.; Huang, C.-C.; Shyur, L.-F. Echinacea Alkamides Prevent Lipopolysaccharide/d-GalactosamineInduced Acute Hepatic Injury through JNK Pathway-Mediated HO-1 Expression. J. Agric. Food Chem. 2011, 59, 11966-11974. [CrossRef]

276. Park, S.Y.; Seetharaman, R.; Ko, M.J.; Kim, D.Y.; Kim, T.H.; Yoon, M.K.; Kwak, J.H.; Lee, S.J.; Bae, Y.S.; Choi, Y.W. Ethyl linoleate from garlic attenuates lipopolysaccharide-induced pro-inflammatory cytokine production by inducing heme oxygenase-1 in RAW264.7 cells. Int. Immunopharmacol. 2014, 19, 253-261. [CrossRef] [PubMed]

277. Fukuda, N.; Zhang, L.; Kodama, M.; Sakono, M.; Ide, T.; Yamamoto, K.; Sugano, M. Effect of dietary sesamin on metabolic fate of an exogenous linolelaidic acid in perfused rat liver. J. Nutr. Sci. Vitaminol. 1999, 45, 437-448. [CrossRef] [PubMed]

278. Hamada, N.; Tanaka, A.; Fujita, Y.; Itoh, T.; Ono, Y.; Kitagawa, Y.; Tomimori, N.; Kiso, Y.; Akao, Y.; Nozawa, Y.; et al. Involvement of heme oxygenase-1 induction via Nrf2/ARE activation in protection against H2O2-induced PC12 cell death by a metabolite of sesamin contained in sesame seeds. Bioorg. Med. Chem. 2011, 19, 1959-1965. [CrossRef]

279. Banerjee, P.; Basu, A.; Arbiser, J.L.; Pal, S. The natural product honokiol inhibits calcineurin inhibitor-induced and Ras-mediated tumor promoting pathways. Cancer Lett. 2013, 338, 292-299. [CrossRef]

280. Lu, S.-H.; Hsu, W.-L.; Chen, T.-H.; Chou, T.-C. Activation of Nrf2/HO-1signaling pathway involves the anti-inflammatory activity of magnolol in Porphyromonas gingivalis lipopolysaccharide-stimulated mouse RAW 264.7 macrophages. Int. Immunopharmacol. 2015, 29, 770-778. [CrossRef]

281. Sung, S.H.; Huh, M.S.; Kim, Y.C. New tetrahydrofuran-type sesquilignans of Saururus chinensis root. Chem. Pharm. Bull. 2001, 49, 1192-1194. [CrossRef]

282. Li, B.; Lee, Y.J.; Kim, Y.C.; Yoon, J.J.; Lee, S.M.; Lee, Y.P.; Kang, D.G.; Lee, H.S. Sauchinone from Saururus chinensis protects vascular inflammation by heme oxygenase-1 induction in human umbilical vein endothelial cells. Phytomedicine 2014, 21, 101-108. [CrossRef]

283. Meng, X.; Kim, I.; Jeong, Y.J.; Cho, Y.M.; Kang, S.C. Anti-inflammatory effects of Saururus chinensis aerial parts in murine macrophages via induction of heme oxygenase-1. Exp. Biol. Med. 2016, 241, 461-701. [CrossRef]

284. Ryu, H.S.; Lee, H.K.; Kim, J.S.; Kim, Y.G.; Pyo, M.; Yun, J.; Hwang, B.Y.; Hong, J.T.; Kim, Y.; Han, S.-B. Saucerneol D inhibits dendritic cell activation by inducing heme oxygenase-1, but not by directly inhibiting toll-like receptor 4 signaling. J. Ethnopharmacol. 2015, 166, 92-101. [CrossRef] [PubMed]

285. Willför, S.M.; Ahotupa, M.O.; Hemming, J.E.; Reunanen, M.H.; Eklund, P.C.; Sjöholm, R.E.; Eckerman, C.S.; Pohjamo, S.P.; Holmbom, B.R. Antioxidant activity of knotwood extractives and phenolic compounds of selected tree species. J. Agric. Food Chem. 2003, 51, 7600-7606. [CrossRef] [PubMed]

286. Bajpai, V.K.; Alam, M.B.; Quan, K.T.; Kwon, K.-R.; Ju, M.-K.; Choi, H.-J.; Lee, J.S.; Yoon, J.-I.; Majumder, R.; Rather, I.A. Antioxidant efficacy and the upregulation of Nrf2-mediated HO-1 expression by (+)-lariciresinol, a lignan isolated from Rubia philippinensis, through the activation of p38. Sci. Rep. 2017, 7, 46035. [CrossRef] [PubMed]

287. Erbil, Y.; Doğru-Abbasoğlu, S.; Yanık, B.T.; Alış, H.; Olgaç, V.; Toker, G.A. The effect of heme oxygenase-1 induction by glutamine on TNBS-induced colitis. Int. J. Colorectal Dis. 2007, 22, 591-599.

288. Auld, F.; Maschauer, E.L.; Morrison, I.; Skene, D.J.; Riha, R.L. Evidence for the efficacy of melatonin in the treatment of primary adult sleep disorders. Sleep Med. Rev. 2017, 34, 10-22. [CrossRef]

289. Reiter, R.J. Pineal melatonin: Cell biology of its synthesis and of its physiological interactions. Endocr. Rev. 1991, 12, 151-180. [CrossRef]

290. Arnao, M.B.; Hernández-Ruiz, J. Functions of melatonin in plants: A review. J. Pineal Res. 2015, 59, $133-150$. [CrossRef]

291. Butterfield, D.A. $\beta$-Amyloid-associated free radical oxidative stress and neurotoxicity: Implications for Alzheimer's disease. Chem. Res. Toxicol. 1997, 10, 495-506. [CrossRef]

292. Markesbery, W.R. Oxidative stress hypothesis in Alzheimer's disease. Free Radic. Biol. Med. 1997, 23, $134-147$. [CrossRef] 
293. Clapp-Lilly, K.L.; Smith, M.A.; Perry, G.; Harris, P.L.; Zhu, X.; Duffy, L.K. Melatonin acts as antioxidant and pro-oxidant in an organotypic slice culture model of Alzheimer's disease. Neuroreport 2001, 12, 1277-1280. [CrossRef]

294. Kwon, K.J.; Kim, J.N.; Kim, M.K.; Lee, J.; Ignarro, L.J.; Kim, H.J.; Shin, C.Y.; Han, S.H. Melatonin synergistically increases resveratrol-induced heme oxygenase-1 expression through the inhibition of ubiquitin-dependent proteasome pathway: A possible role in neuroprotection. J. Pineal Res. 2011, 50, 110-123. [CrossRef] [PubMed]

295. Kang, J.W.; Lee, S.M. Melatonin inhibits type 1 interferon signaling of toll-like receptor 4 via heme oxygenase-1 induction in hepatic ischemia/reperfusion. J. Pineal Res. 2012, 53, 67-76. [CrossRef] [PubMed]

296. Park, J.M.; Han, Y.M.; Kangwan, N.; Lee, S.Y.; Jung, M.K.; Kim, E.H.; Hahm, K.B. S-allyl cysteine alleviates nonsteroidal anti-inflammatory drug-induced gastric mucosal damages by increasing cyclooxygenase-2 inhibition, heme oxygenase-1 induction, and histone deacetylation inhibition. J. Gastroenterol. Hepatol. 2014, 29, 80-92. [CrossRef]

297. Choi, B.-M.; Kim, S.-M.; Park, T.-K.; Li, G.; Hong, S.-J.; Park, R.; Chung, H.-T.; Kim, B.-R. Piperine protects cisplatin-induced apoptosis via heme oxygenase-1 induction in auditory cells. J. Nutr. Biochem. 2007, 18, 615-622. [CrossRef] [PubMed]

298. Yamasaki, H. Pharmacology of sinomenine, an anti-rheumatic alkaloid from Sinomenium acutum. Acta Medica Okayama 1976, 30.

299. Song, S.; Shen, X.; Tang, Y.; Wang, Z.; Guo, W.; Ding, G.; Wang, Q.; Fu, Z. Sinomenine pretreatment attenuates cold ischemia/reperfusion injury in rats: The role of heme oxygenase-1. Int. Immunopharmacol. 2010, 10, 679-684. [CrossRef] [PubMed]

300. Ha, Y.M.; Kim, M.Y.; Park, M.K.; Lee, Y.S.; Kim, Y.M.; Kim, H.J.; Lee, J.H.; Chang, K.C. Higenamine reduces HMGB1 during hypoxia-induced brain injury by induction of heme oxygenase-1 through PI3K/Akt/Nrf-2 signal pathways. Apoptosis 2012, 17, 463-474. [CrossRef]

301. Zhang, Z.; Li, M.; Wang, Y.; Wu, J.; Li, J. Higenamine promotes M2 macrophage activation and reduces Hmgb1 production through HO-1 induction in a murine model of spinal cord injury. Int. Immunopharmacol. 2014, 23, 681-687. [CrossRef]

302. Zhou, L.; Du, L.; Chen, X.; Li, X.; Li, Z.; Wen, Y.; Li, Z.; He, X.; Wei, Y.; Zhao, X. The antitumor and antimetastatic effects of $\mathrm{N}$-trimethyl chitosan-encapsulated camptothecin on ovarian cancer with minimal side effects. Oncol. Rep. 2010, 24, 941-948.

303. Stewart, A.F.; Schütz, G. Camptothecin-induced in vivo topoisomerase I cleavages in the transcriptionally active tyrosine aminotransferase gene. Cell 1987, 50, 1109-1117. [CrossRef]

304. Jayasooriya, R.G.P.T.; Park, S.R.; Choi, Y.H.; Hyun, J.-W.; Chang, W.-Y.; Kim, G.-Y. Camptothecin suppresses expression of matrix metalloproteinase-9 and vascular endothelial growth factor in DU145 cells through PI3K/Akt-mediated inhibition of NF-kB activity and Nrf2-dependent induction of HO-1 expression. Environ. Toxicol. Pharmacol. 2015, 39, 1189-1198. [CrossRef] [PubMed]

305. Mahmoud, A.M.; Germoush, M.O.; Soliman, A.S. Berberine attenuates isoniazid-induced hepatotoxicity by modulating peroxisome proliferator-activated receptor gamma, oxidative stress and inflammation. Int. J. Pharmacol. 2014, 10, 451-460. [CrossRef]

306. Germoush, M.O.; Mahmoud, A.M. Berberine mitigates cyclophosphamide-induced hepatotoxicity by modulating antioxidant status and inflammatory cytokines. J. Cancer Res. Clin. Oncol. 2014, 140, 1103-1109. [CrossRef] [PubMed]

307. Mahmoud, A.M.; Abdel-Rahman, M.M.; Bastawy, N.A.; Eissa, H.M. Modulatory effect of berberine on adipose tissue PPAR $\gamma$, adipocytokines and oxidative stress in high fat diet/streptozotocin-induced diabetic rats. J. Appl. Pharm. Sci 2017, 7.

308. Mahmoud, A.M.; Hozayen, W.G.; Ramadan, S.M. Berberine ameliorates methotrexate-induced liver injury by activating Nrf2/HO-1 pathway and PPAR $\gamma$, and suppressing oxidative stress and apoptosis in rats. Biomed. Pharmacother. 2017, 94, 280-291. [CrossRef]

309. Reyes-Escogido, M.D.L.; Gonzalez-Mondragon, E.G.; Vazquez-Tzompantzi, E. Chemical and pharmacological aspects of capsaicin. Molecules 2011, 16, 1253-1270. [CrossRef] 
310. Joung, E.-J.; Li, M.-H.; Lee, H.G.; Somparn, N.; Jung, Y.S.; Na, H.-K.; Kim, S.-H.; Cha, Y.-N.; Surh, Y.-J. Capsaicin Induces Heme Oxygenase-1 Expression in HepG2 Cells Via Activation of PI3K-Nrf2 Signaling: NAD(P)H:Quinone Oxidoreductase as a Potential Target. Antioxid. Redox Signal. 2007, 9, 2087-2098. [CrossRef]

311. Kim, Y.; Lee, J. Anti-Inflammatory Activity of Capsaicin and Dihydrocapsaicin through Heme Oxygenase-1 Induction in Raw264.7 Macrophages. J. Food Biochem. 2014, 38, 381-387. [CrossRef]

312. Zhang, H.-F.; Shi, L.-J.; Song, G.-Y.; Cai, Z.-G.; Wang, C.; An, R.-J. Protective effects of matrine against progression of high-fructose diet-induced steatohepatitis by enhancing antioxidant and anti-inflammatory defences involving Nrf2 translocation. Food Chem. Toxicol. 2013, 55, 70-77. [CrossRef]

313. Zhang, B.; Liu, Z.-Y.; Li, Y.-Y.; Luo, Y.; Liu, M.-L.; Dong, H.-Y.; Wang, Y.-X.; Liu, Y.; Zhao, P.-T.; Jin, F.-G. Antiinflammatory effects of matrine in LPS-induced acute lung injury in mice. Eur. J. Pharm. Sci. 2011, 44, 573-579. [CrossRef]

314. Liu, Y.; Xu, Y.; Ji, W.; Li, X.; Sun, B.; Gao, Q.; Su, C. Anti-tumor activities of matrine and oxymatrine: Literature review. Tumor Biol. 2014, 35, 5111-5119. [CrossRef] [PubMed]

315. Liu, X.; Zhang, X.; Ma, K.; Zhang, R.; Hou, P.; Sun, B.; Yuan, S.; Wang, Z.; Liu, Z. Matrine alleviates early brain injury after experimental subarachnoid hemorrhage in rats: Possible involvement of PI3K/Akt-mediated NF-KB inhibition and Keap1/Nrf2-dependent HO-1 inductionn. Cell Mol. Biol. 2016, 62, 38-44. [PubMed]

316. Gai, G.-z.; Jin, S.-j;; Wang, B.; Li, Y.; Li, C. The efficacy of Cordyceps militaris capsules in treatment of chronic bronchitis in comparison with Jinshuibao capsules. Chin. New Drugs J. 2004, 13, 169-170.

317. Zeng, Y.; Lian, S.; Li, D.; Lin, X.; Chen, B.; Wei, H.; Yang, T. Anti-hepatocarcinoma effect of cordycepin against NDEA-induced hepatocellular carcinomas via the PI3K/Akt/mTOR and Nrf2/HO-1/NF-kB pathway in mice. Biomed. Pharm. 2017, 95, 1868-1875. [CrossRef] [PubMed]

318. Rukachaisirikul, T.; Prabpai, S.; Champung, P.; Suksamrarn, A. Chabamide, a novel piperine dimer from stems of Piper chaba. Planta Med. 2002, 68, 853-855. [CrossRef] [PubMed]

319. Ngo, Q.T.; Tran, P.T.; Tran, M.H.; Kim, J.A.; Rho, S.S.; Lim, C.H.; Kim, J.C.; Woo, M.H.; Choi, J.S.; Lee, J.H. Alkaloids from Piper nigrum exhibit antiinflammatory activity via activating the Nrf2/HO1 pathway. Phytother. Res. 2017, 31, 663-670. [CrossRef] [PubMed]

320. Lee, H.-N.; Jin, H.-O.; Park, J.-A.; Kim, J.-H.; Kim, J.-Y.; Kim, B.; Kim, W.; Hong, S.-E.; Lee, Y.-H.; Chang, Y.H. Heme oxygenase-1 determines the differential response of breast cancer and normal cells to piperlongumine. Mol. Cells 2015, 38, 327. [CrossRef] [PubMed]

321. Lu, W.; Shi, L.; Gao, J.; Zhu, H.; Hua, Y.; Cai, J.; Wu, X.; Wan, C.; Zhao, W.; Zhang, B. Piperlongumine Inhibits Zika Virus Replication In vitro and Promotes Up-Regulation of HO-1 Expression, Suggesting An Implication of Oxidative Stress. Virol. Sin. 2020,1-11.

322. Liu, S.; Yang, T.; Ming, T.W.; Gaun, T.K.W.; Zhou, T.; Wang, S.; Ye, B. Isosteroid alkaloids from Fritillaria cirrhosa bulbus as inhibitors of cigarette smoke-induced oxidative stress. Fitoterapia 2020, 140, 104434. [CrossRef]

323. Xu, J.; Zhao, W.; Pan, L.; Zhang, A.; Chen, Q.; Xu, K.; Lu, H.; Chen, Y. Peimine, a main active ingredient of Fritillaria, exhibits anti-inflammatory and pain suppression properties at the cellular level. Fitoterapia 2016, 111, 1-6. [CrossRef]

324. Luo, Z.; Zheng, B.; Jiang, B.; Xue, X.; Xue, E.; Zhou, Y. Peiminine inhibits the IL-1 $\beta$ induced inflammatory response in mouse articular chondrocytes and ameliorates murine osteoarthritis. Food Funct. 2019, 10, 2198-2208. [CrossRef] [PubMed]

325. Duvigneau, J.C.; Esterbauer, H.; Kozlov, A.V. Role of heme oxygenase as a modulator of heme-mediated pathways. Antioxidants 2019, 8, 475. [CrossRef] [PubMed]

Publisher's Note: MDPI stays neutral with regard to jurisdictional claims in published maps and institutional affiliations. 